\title{
Comparecencia de Samuel G. Inman, presunto simpatizante de la Revolución mexicana frente a daños a estadounidenses
}

Jesús Méndez Reyes*

Entre el verano de 1919 y el otoño de 1920, el Comité de Relaciones Exteriores del Senado de Estados Unidos llevó a cabo diversas entrevistas entre compatriotas asentados en México durante el periodo de la Revolución. El Comité estuvo encabezado por el Senador Albert Bacon Fall (1861-1944), por lo que los relatos transcritos y luego publicados fueron conocidos como los papeles de la Comisión Fall conforme a las resoluciones 106 y $163 \mathrm{del}$ Senado para investigar "los casos de daños y abusos sufridos por ciudadanos de Estados Unidos en la República Mexicana, así como los montos de las indemnizaciones". ${ }^{1}$

Senador electo en 1912, Albert B. Fall se hizo cargo de las comparecencias y lo caracterizó la dureza con la que acusaba e intimidaba a quienes se hallaban frente al estrado, con el propósito de tener argumentos y exigir compensaciones al gobierno mexicano, proponer la intervención del país vecino o bien remover al presidente Venustiano Carranza que encabezó la promulgación de la Constitución de 1917. Como podrá leerse en la comparecencia, se prefería a Victoriano Huerta sobre el presidente Madero o el propio Carranza que entre otras disposiciones, declaró los bienes del subsuelo mexicano como propiedad de la Nación. La nueva legislación rechazaba la preeminencia de los extranjeros en sectores como la minería, el petróleo, las explotaciones agrarias, la extracción de agua, etcétera.

Fall se desempeñó más tarde como Secretario del Interior durante la presidencia de Warren G. Harding (1921-1923) y, paradójicamente, el mismo

* Universidad Autónoma de Baja California, correo electrónico: jmreyes@uabc.edu.mx

$166^{\circ}$ Congreso del Senado de Estados Unidos, Investigación sobre Asuntos Mexicanos, Reporte Preliminar y Audiencias del Comité de Relaciones Exteriores relativas a la resolución del Senado 106, sobre los abusos cometidos contra ciudadanos de los Estados Unidos en México, $2^{\mathrm{a}}$ sesión, no. 285, Washington, Oficina Impresora del Gobierno, 1920, 2 volúmenes. 
Senado reveló en 1924, que Albert B. Fall había recibido sobornos de parte de empresarios petroleros de Wyoming y California. Cinco años más tarde fue declarado culpable y cumplió nueve meses de prisión de una condena por un año.

Entre los distintos personajes que fueron llamados a comparecer estuvo el doctor Samuel G. Inman, misionero evangélico, escritor y erudito cuya labor en el norte de México fue censurada por simpatizar con los nacionales o tratar de contrarrestar las acusaciones por daños a propiedades de estadounidenses. La extensa comparecencia de Inman se presenta en tres secciones, las dos primeras fueron publicadas en los números 7 (2013) y 10 (2015) de Meyibó Revista de Investigaciones Históricas de la Universidad Autónoma de Baja California. La tercera y última parte que mostramos en esta ocasión vuelve a evidenciar los intereses económicos y políticos en juego de aquellos años, así como referencias valiosas sobre la labor de los misioneros protestantes de Estados Unidos durante la Revolución mexicana y sus afinidades con algunos postulados de la Constitución, como la defensa del laicismo y la libertad de creencias.

Las notas a pie de página no son del original en inglés, se decidió agregarlas para ilustrar la lectura al público no especializado. Por último debo señalar que la traducción libre al español de una veintena de entrevistas de la Comisión Fall las realizamos quien esto escribe, la maestra Silvia Cuesy y la maestra Grisell Ortega, en ese momento estudiante de la licenciatura en Historia de la Universidad Nacional Autónoma de México. Esta labor la llevamos a cabo en el Instituto Nacional de Estudios Históricos de las Revoluciones de México (INEHRM) entre los años 2003 y 2005.

$\Omega$

Martes, 9 septiembre, 1919

Senado de los Estados Unidos,

Subcomité del Comité de Relaciones Exteriores,

Washington, D.C.

El subcomité se reunió, conforme al aplazamiento, a las 11.20 a.m., en el salón 422, Edificio de las oficinas del Senado, Senador Albert B. Fall presidiendo.

Presentes: Senadores Fall (presidente) y Brandegee.

El PRESIDENTE. El comité entrará en sesión. Dr. Inman, reanudará su comparecencia. 
TESTIMONIO DEL DR. SAMUEL GUY INMAN - Resumido.

El PRESIDENTE. Doctor, había algunos nombres y, me parece, algunos documentos que usted quería identificar y archivar con el Comité. Nombres que usted quería darnos y algunos documentos que usted quería conservar. Si está listo, procederemos con eso. Si prefiere hacer más declaraciones ahora, antes de archivar sus documentos o de darnos los nombres, siga su propio rumbo.

Dr. INMAN. Gracias Señor Presidente, en referencia al asunto de mi carta que tuvimos ante nosotros ayer por la tarde, me gustaría leer una respuesta a la única carta que he recibido, que trata alguno de los asuntos petroleros, y decir que queda clara mi postura. Esa carta está fechada el 19 de agosto de 1919 y va dirigida al señor Ira Jewell Williams.

Senador BRANDEGEE. ¡Quién la firma?

Señor INMAN. Está firmada por mí. La carta dice lo siguiente:

19 de Agosto de 1919.

Señor Ira Jewell Williams, 1424 Chestnue Street, Philadelphia, Pa.

Querido Señor: Permítame contestar su carta del 13 de agosto que ha llegado a mi oficina, en la cual usted protesta en contra de declaraciones publicadas que se supone fueron hechas por el abajo firmante concernientes a la propaganda a favor de la intervención en México.

Déjeme decir que mi principal interés en todo este asunto es prevenir la intervención, la cual, estoy convencido, será absolutamente injusta y poco cristiana. Creo que es mi deber frente a la particular causa a la que sirvo y frente a mi país hacer todo lo que pueda para prevenir la intervención. En cumplimiento con dicha obligación escribí una carta personal “A los representantes de las juntas de la embajada presentes en la conferencia de la Ciudad de México, febrero 1919", llamando la atención a la propaganda difundida a favor de la intervención en México, diciendo que estaba sorprendido que ciertos hombres que habían luchado contra el movimiento dijeron a un grupo de personas interesadas dicha propaganda, particularmente la de los intereses petroleros. Entonces, cité lo que uno de nuestros predicadores mexicanos me había dicho sobre lo que la intervención significaría y exhortó a nuestras fuerzas diplomáticas a usar su influencia con el Congreso y la prensa religiosa, dado que la prensa periódica estaba muy cerrada a cualquier trabajo contra la intervención.

Esta era una carta personal y no se proponía su publicación. Fue entregada a la imprenta sin mi conocimiento.

La carta representa mis convicciones actuales. Nadie que lea los periódicos puede dudar que haya propaganda que apoya la intervención. Un editorial idéntico, con exactamente las mismas palabras, favoreciendo la intervención, apareció recientemente en ocho periódicos diferentes en regiones extensamente separadas de este país en un plazo de cuatro días. La misma administración de Washington, de acuerdo con los despachos de la Prensa Asociada, ha decidido que la propaganda es tan descarada que debe de ser detenida. El New York Times recientemente describió cuatro supuestos tipos de propaganda relativa a 
México y dio información detallada concerniente a un medio propagandístico que representa a algunas de las preocupaciones petroleras.

The Nation ha publicado recientemente una serie de artículos en los que cargos directos son levantados contra organizaciones petroleras identificadas y su propia conexión con la propaganda referida. El abogado Gibbons ha publicitado recientemente un libro completo abogando por la intervención. Así que no logro entender por qué una declaración mía, que de casualidad apareció en los periódicos, deba causar tanta agitación.

No he presentado cargo alguno contra individuo u organización, si alguien desea asumirse como referido, puede presentar pruebas claras de que lo he representado de forma tergiversada y estaré, por supuesto, contento de reconocer mi error. Eso seguramente no resultará ser menos "difamatorio y falso", como ustedes han llamado a mis declaraciones, que la carta recientemente publicada en el New York Times en la que una sociedad de petroleros se refiere a mí como un propagandista carrancista.

En lo que concierne a sus referencias a la nueva Constitución en México y a todas las cuestiones relacionadas, encontrará que mi opinión, después de una cuidadosa investigación, son el verdadero asunto de mi libro, Intervención en México, en el que me he empeñado en presentar toda la situación con la actitud más comprensiva posible frente a todos los involucrados. Repito que mi interés en todo el asunto es prevenir la intervención en México, lo que creo que sería un imperdonable pecado nacional, cuando nosotros acabamos de salir de una guerra para terminar las guerras y cuando México está comenzando a regresar a la vida normal. Estaré gustoso de cooperar con cualquiera de las fuerzas decentes que sean de la misma opinión.

Suyo, atentamente,

S.G. INMAN.

Señor presidente, lamento traer a colación este asunto otra vez, pero siento que debo presentar esa carta y también hacer esta declaración adicional, dado que ayer nos detuvimos tanto en esta cuestión.

Desde la expedición de mi carta, a la que se ha hecho referencia, he estado más convencido de las prácticas injustas de algunos de los intereses petroleros en México, especialmente debido a sus ataques personales a mi persona y sus intentos de intimidarme. He sido amenazado con una demanda por difamación. Se ha publicado que soy un propagandista carrancista, se ha atacado mi reputación, insinuando que yo era deshonesto en mi tentativa contra la intervención, ha hecho falsas declaraciones sobre mis actividades, los miembros de mi comité y el trabajo de estos.

No deseo llevar este asunto al Senado, no me parece que sea pertinente, ni me interesa seguir la controversia con ninguno de los petroleros, pero dado que usted tiene una copia de la única carta que he escrito a los petroleros — usted me dijo ayer que tenía copia de la carta que acabo de leer-.

El PRESIDENTE. ¿Escrita al señor Williams?

Dr. INMAN. Sí.

El PRESIDENTE. Sí; la tengo frente a mí. 
Dr. INMAN. Supongo que ellos la proporcionaron a usted, para poder presentarla al Comité. Este intento continuo de intimidarme me conduce a hacer esta declaración, la que espero sea mi última en este asunto.

Senador BRANDEGEE. ¿Qué es lo que está leyendo?

Dr. INMAN. ¿Ésta? [Señalando un documento]

Senador BRANDEGEE. Sí.

Dr. INMAN. Simplemente una carta, una nota breve.

Senador BRANDEGEE. ¿Algún texto que escribió para leer frente a este comité? Dr. INMAN. Sí, señor; lo escribí esta mañana.

El PRESIDENTE. ¿Está leyendo esa nota al Comité con la esperanza de que le permita sea su última palabra sobre el asunto?

Dr. INMAN. Sí.

El PRESIDENTE. Lamento que usted haga esa petición. El Comité no va a permitir a ningún testigo que se presente frente a él, hacer una declaración de su propia resolución y cerrar la audiencia con esa proposición.

Dr. INMAN. Bueno, a mí simplemente me pareció, señor Presidente, que dado que se gastó tanto tiempo en ese asunto ayer, y manifiestamente estuve muy confundido por toda esta cuestión. No estaba familiarizado con mis derechos como testigo o algo parecido, de manera que mi intención fue evitar hacer declaraciones personales en general. No tengo ganas de tratar el asunto. De hecho, no me gustaría, señor Presidente, entrar en ello, pero simplemente hago esta declaración, porque me parece que su Comité debería admitir esta declaración, que he obtenido de muchas y diversas fuentes.

Senador BRANDEGEE. Ya está en el registro. Lo ha leído como parte de su testimonio y se ha admitido en el registro. ¿A qué se refiere cuando habla de intimidarlo? ¿Quién está intentando intimidarlo?

Dr. INMAN. Como ya lo dije, señor Presidente, preferiría no discutir más este asunto. La carta que he entregado explica mi posición y la declaración que acabo de leer explicita a lo que me refiero.

Senador BRANDEGEE. Usted viene aquí, lee una declaración escrita que preparó en la que expone que hay un intento de intimidarlo. Yo le pregunto ¿a qué se refiere con eso y quién está intentando intimidarlo, y usted agrega que no tiene ganas de contestar?

Dr. INMAN. He explicado eso en mi declaración.

Senador BRANDEGEE. Podré ser estúpido y obtuso sobre el particular. ¿Contestará mi pregunta? ¿Quién intenta intimidarlo?

Dr. INMAN. Dije que he sido amenazado con una demanda por difamación y la Asociación para la Protección de los Derechos de los Estadounidenses en México ha publicado que yo soy un propagandista carrancista, así como un representante ha atacado mi reputación con sus insinuaciones...

Senador BRANDEGEE. Espere un minuto. ¿Quién ha intentado intimidarlo? Dr. INMAN. Creo que aquellas palabras son lo suficientemente claras, Senador. Senador BRANDEGEE. ¿Quién es? Usted dice que ha sido amenazado con una demanda por difamación, por quién?

Dr. INMAN. Hago esa declaración aquí.

Senador BRANDEGEE. Usted no responde ninguna de mis preguntas, Doctor, le pregunto ¿Quién ha amenazado con demandarlo por difamación? 
Dr. INMAN. ¿Debo leer esto otra vez?

Senador BRANDEGEE. No; deme el nombre del individuo que ha amenazado demandarlo por difamación.

Dr, INMAN. Pienso que aquí lo dice claramente.

Senador BRANDEGEE. ¡Bueno, démelo! ¿Puede? ¿Usted sabe quién es, o no?

Dr. INMAN. Acabo de hacer una solicitud frente al Comité para que permita sumar esta declaración en el expediente.

Senador BRANDEGEE. Ya está incluida.

Dr. INMAN. Y también que esa fue mi última declaración sobre este asunto.

Senador BRANDEGEE. Ya lo sé; pero tengo el derecho de interrogarlo sobre su testimonio. Usted ha venido aquí y leyó el escrito que está en el registro, en el cual usted hace ciertas declaraciones, una de las cuales es que alguien trata de intimidarlo. Usted no ha declarado quién es esa persona. Otro es que alguien ha amenazado con demandarlo por difamación. Usted no ha declarado quién es esa persona. Le pido que me diga qué individuos son en cada caso. ¿Declina contestar?

Dr. INMAN. Si tengo el derecho a hacerlo, sí declino.

Senador BRANDEGEE. Muy bien. Usted ha declarado que ayer no estaba familiarizado con sus derechos como testigo. ¿Está familiarizado con ellos hoy? Dr. INMAN. No, señor; no lo estoy.

Senador BRANDEGEE. ¿Desea usted ejercer algún derecho aquí?

Dr. INMAN. No, señor; no lo deseo. Simplemente quiero incluir en esta declaración lo que a mí me parece justo, y después cerrar este asunto, que no me parece de pertinencia a este Comité. Quiero decir que tengo una cita con el señor Williams en la cual espero que discutamos todos estos asuntos, me parece que ese es el lugar para que nosotros aclaremos cualquier diferencia personal, mejor lugar que aquí. Por lo tanto, debido a todas las cosas que están implicadas prefiero no discutir más el tema.

Senador BRANDEGEE. Por supuesto, si usted declina contestar las preguntas, no lo presionaré más. ¿Quién es el señor Williams con el que dice tener una cita? Dr. INMAN. Este caballero al que le escribí la última carta.

Senador BRANDEGEE. ¿Quién es él?

Dr. INMAN. Me parece que él es presidente, o al menos está relacionado con la Boston Oil Company.

Senador BRANDEGEE. No más preguntas, señor Presidente.

El PRESIDENTE. ¿Está presente el señor Williams?

Señor WILLIAMS. El señor Williams está presente, señor.

Senador BRANDEGEE. ¿Intenta dar a entender en su declaración en la que menciona que ayer no estaba familiarizado con sus derechos, y dice que no desea ejercer ningún derecho hoy, o afirmar que le han sido negados sus derechos?

Dr. INMAN. No, señor.

Senador BRANDEGEE. Entonces no veo la relevancia de la declaración. Eso es todo lo que quiero preguntar.

El PRESIDENTE. Doctor ¿Está dispuesto a que se haga público en esta asamblea y a las iglesias de este país que, después de haber declarado como lo acaba de hacer, ha sido intimidado y ha sido atacado? ¿Que ha sido amenazado con una 
demanda por difamación y que por esa razón usted declina continuar la discusión relacionada con su carta, sobre la cual fue interrogado ayer?

Señor INMAN. Sí, señor.

El PRESIDENTE. ¿Usted quiere que eso se sepa en las iglesias?

Dr. INMAN. Estoy dispuesto a que eso se sepa.

El PRESIDENTE. ¿Es su propósito dar la impresión al público que este comité no lo ayudó de ninguna forma en la defensa de sus intereses?

Dr. INMAN. Por supuesto que no lo es.

El PRESIDENTE. ¿Por qué declina entonces seguir discutiendo el asunto con el Comité en este momento? ¿No considera esto como una crítica al mismo Comité que usted lea tal declaración y después se niegue a seguir adelante?

Dr. INMAN. No veo cómo eso sea una crítica del Comité. No tenía idea de eso.

El PRESIDENTE. Pienso, Dr. Inman, que usted fue aconsejado para estar debidamente notificado, en este momento, que el Comité piensa que puede hacerlo entrar en el asunto, y sus miembros consultarán después qué rumbo tomarán en este asunto.

En relación con esta declaración del Dr. Inman, el presidente presenta para archivar en el registro una carta del 3 de septiembre de 1919, dirigida al señor James G. McDonald, presidente de la Liga de la Asociación de Naciones Libres, ${ }^{2}$ 130 West Forty-second Street, New York City. Dicha carta está dirigida al Dr. McDonald y solicita que él notifique a todo el Comité, a pudiera acudir a las audiencias y presentar al Comité todos los documentos, etcétera.

(La carta a la que se hace referencia es la siguiente:)

3 de septiembre, 1919.

Señor James G. McDonald,

Presidente de la Liga de la Asociación de Naciones Libres, 130 West Fortysecond Street, New York City.

Mi estimado señor McDonald: En referencia a sus favores del día 13 y 14 del mes pasado, tengo instrucciones del Senador Fall de agradecerle y disculparme por no haber contestado antes su mensaje. La razón de esta demora es que los miembros del subcomité han estado tan absortos en los deberes relativos al reporte de la Liga de Naciones, que no han podido juntarse para perfeccionar su organización.

Estoy complacido de aconsejarle, sin embargo, que el Comité espera comenzar las audiencias el próximo lunes 8 de septiembre, y de conformidad con su muy generosa oferta que data del día 14 del mes pasado, se me instruye para solicitar que usted y los miembros de su asociación — que componen el comité referido y visitaron México recientemente- comparezcan frente al comité a las

2 League of Free Nations Association fundada en 1918 por el periodista Paul U. Kellogg. Creada para apoyar al presidente Woodrow Wilson en su esfuerzo por mantener la paz mundial y apuntalar los Acuerdos de Versalles con los que finalizó la Primera Guerra Mundial. Estuvo encabezada por "los Cuatro Grandes", Gran Bretaña, Italia, Francia y el propio Estados Unidos. 
11 hrs. a.m. en dicha fecha.

También tengo instrucciones del comité para pedir que los testigos traigan consigo toda evidencia documental, mapas y otros datos que pudieran ser de utilidad en esta investigación. Tengo instrucciones para solicitar, especialmente, que el señor Samuel Guy Inman, mencionado en su carta del día 13, esté presente.

Recibido este comunicado, sea tan amable de telegrafiar al firmante o directamente al Senador Fall, informando si será conveniente comparecer con base en esta petición, informando también si será necesario citar a alguno de estos testigos.

Atentamente.

\section{DAN M. JACKSON, Secretario del Subcomité.}

E1 PRESIDENTE. También archive una carta del 4 de septiembre de 1919, dirigida al señor James G. McDonald, con referencia a cierto asunto propagandístico enviado por la Liga de Naciones Libres, la que contenía una exposición de los derechos de mexicanos para confiscar las propiedades petroleras en México, siendo documentos presentados del Oil and Paint Journal.

(La carta referida es la siguiente:)

4 de septiembre, 1919.

Señor JAMES G. McDONALD,

Presidente de la Liga de la Asociación de Naciones Libres, 30 West Forty-second Street, New York City.

Mi estimado señor McDonald: Complementando mi carta de ayer, el Comité estaría agradecido si el autor del artículo "México y la explotación de petróleo. Un estudio oficial de los jefes de la comisión petrolera" — contenido en la prueba presentada del Oil, Paint and Drug Reporter, y publicado en Nueva York el 11 de agosto de 1919 — acompaña a los otros testigos a la audiencia del 8 de septiembre de 1919.

El Comité le agradecerá que solicite que el autor arriba mencionado traiga con él todos los documentos, libros u otras referencias con las cuales preparó el interesante escrito antes mencionado. Lamento que este mensaje no estuviera en mi carta de ayer, pero la misma fue dictada apresuradamente al finalizar el día, y por un descuido este asunto no fue incluido. Le agradeceré que interprete este mensaje en relación con mi carta de fecha del 3 de septiembre.

Sinceramente, suyo.

DAN M. JACKSON, Secretario del Subcomité.

E1 PRESIDENTE. También archive una carta del 4 de septiembre de 1919, dirigida al señor James G. McDonald, con referencia a cierto asunto propagandístico 
enviado por la Liga de Naciones Libres, la que contenía una exposición de los derechos de mexicanos para confiscar las propiedades petroleras en México, siendo documentos presentados del Oil and Paint Journal.

(La carta referida es la siguiente:)

4 de septiembre, 1919.

Señor JAMES G. McDONALD, Presidente de la Liga de la Asociación de Naciones Libres, 130 West Fortysecond Street, New York City.

Mi estimado señor McDonald: Complementando mi carta de ayer, el Comité estaría agradecido si el autor del artículo "México y la explotación de petróleo. Un estudio oficial de los jefes de la comisión petrolera" - contenido en la prueba presentada del Oil, Paint and Drug Reporter, y publicado en Nueva York el 11 de agosto de 1919 - acompaña a los otros testigos a la audiencia del 8 de septiembre de 1919.

El Comité le agradecerá que solicite que el autor arriba mencionado traiga con él todos los documentos, libros u otras referencias con las cuales preparó el interesante escrito antes mencionado. Lamento que este mensaje no estuviera en mi carta de ayer, pero la misma fue dictada apresuradamente al finalizar el día, y por un descuido este asunto no fue incluido. Le agradeceré que interprete este mensaje en relación con mi carta de fecha del 3 de septiembre.

Sinceramente, suyo.

DAN M. JACKSON, Secretario del Subcomité.

El PRESIDENTE. También adjunto una copia del telegrama de 6 de septiembre dirigida al Doctor McDonald como respuesta a la carta del Comité de 4 de septiembre, en la que notifica que el testigo aquí presente, el Dr. Inman, estaría aquí, pero que el Dr. Winton, el señor Trowbridge y el Dr. Slaughter no estaban disponibles en ese momento.

El telegrama del 6 de septiembre que envié como Presidente, notificó al Dr. McDonald que habíamos arreglado esta audiencia solicitada por él con el propósito de escuchar a todo el Comité y, con especial referencia a los dos últimos párrafos de su carta, en los que llamó la atención sobre los injustos métodos seguidos por esta Cámara en la investigación, declarando, con referencia a los señores Inman, Trowbridge, Winton y Slaughter.

Le pido urgentemente que telegrafíe a estos caballeros ausentes para que comparezcan como testigos inmediatamente. También telegrafíe sus nombres completos y direcciones, en citaciones separadas que podrán ser enviadas a donde quiera que ellos estén.

Estaremos encantados de tener libros, documentos, etcétera, para archivarlos al Comité, advirtiendo que esta audiencia estará llena y cada testigo será interrogado con base en las fuentes de información, las cuestiones en las que 
fundamentan sus argumentos, las afirmaciones y conclusiones contenidas en esos libros y otros escritos. Posterior a la interrogación del Comité proponemos la inmediata citación de todos los prominentes petroleros [y] estadounidenses con intereses en México. Las citaciones se enviarán por telegrama firmados por mí como Presidente del Comité, acompañada por un escrito y la ratificación por correo en la misma fecha.

(El telegrama del 6 de septiembre, al que se refiere el presidente, y la carta de ratificación de la misma fecha se copian íntegras aquí, como sigue:)

\section{[Telegrama.]}

6 de septiembre de 1919

JAMES G. McDONALD, 130 West Forty-second Street, New York City:

Estamos arreglando junta del Comité para escucharlo conforme su carta de 14 de agosto y con particular referencia últimos dos párrafos. Comité expidiendo citaciones para usted y doctores Inman, Trowbridge, Winton y Slaughter para comparecer el lunes. Le pido de manera urgente telegrafíe a estos caballeros ausentes para que comparezcan como testigos inmediatamente. También telegrafíe sus nombres completos y direcciones para que en citaciones separadas puedan ser enviadas a donde quiera que ellos estén.

Estaremos encantados de tener libros, documentos, etcétera... con base en las fuentes de información y todas las que fundamenten sus argumentos, afirmaciones y conclusiones. Posterior a la interrogación de su comité proponemos la inmediata citación de todos los prominentes petroleros[y] estadounidenses con intereses en México.

Las citaciones se enviarán por telegrama. Por favor telegrafíe a todos.

\section{ALBERT B. FALL, Presidente Subcomité de Asuntos Mexicanos, Comité de Relaciones Extranjeras.}

DAN M. JACKSON, Secretario del Subcomité.

6 de septiembre, 1919.

El PRESIDENTE. Dr. Inman, quiero llamar su atención sobre el hecho de que el presidente ejecutivo, por boca de quien nos enteramos en primera instancia de su deseo de presentarse frente a este comité, fue notificado por telegrama y carta del 
curso que esta interrogación seguiría. ¿Todavía prefiere negarse a continuar con el asunto sobre el que fue interrogado ayer?

Dr. INMAN. Sí, señor.

El PRESIDENTE. Por el momento vamos a dejar esa cuestión. ¿Quién aportaba el dinero para la campaña anti-intervencionista que usted dirigía?

Dr. INMAN. Lo que sé hasta el momento es que había un pequeño fondo, probablemente $\$ 400.00$, que quedaron de un comité anterior denominado "Comité de Cooperación con México" que operó durante la época en la que Pershing fue allá, justo antes de la expedición de éste, cuando la intervención parecía inminente, y ese fondo ha permanecido desde entonces con el tesorero, mientras el comité estaba inactivo. Cuando algunos de los miembros de ese comité se percataron de la presente crisis, sugirieron a la Liga de Asociación de Naciones Libres, que era una organización activa en ese momento, que designara un comité. Este comité fue nombrado y, me parece, que los viejos fondos fueron traspasados a la Liga de Asociación de Naciones Libres.

El PRESIDENTE. Usted dice que $\$ 400.00$ quedaron en el fondo del antiguo comité, y fueron trasladados a la Liga de Asociación de Naciones Libres, y la Liga ha complementado este fondo. ¿Incluyen estos fondos la cantidad total de dinero que ha sido usado en el trabajo de propaganda?

Dr. INMAN. Sí, señor; a la Liga de Asociación de Naciones Libres, o cualquier otra que yo conozca.

El PRESIDENTE. Estoy hablando de su comité. ¿Quién está pagando sus gastos? Dr. INMAN. Por supuesto, yo soy el secretario ejecutivo del Comité de Cooperación con América Latina. Mi salario proviene de las juntas diplomáticas. Yo no estaba conectado con ninguna de esas organizaciones, pero simplemente fui invitado a entrar como alguien externo para trabajar en dicho comité.

El PRESIDENTE. ¿Qué salario recibe?

Dr. INMAN. Recibo \$3,600.00 anuales.

El PRESIDENTE. ¿Quién paga sus gastos?

Dr. INMAN. El Comité de Cooperación con América Latina.

El PRESIDENTE. ¿No recibe nada por parte de este comité en México o de la Liga de Asociación de Naciones Libres por sus servicios?

Dr. INMAN. No, señor.

El PRESIDENTE. ¿Quiere que la audiencia entienda que el libro que usted ha publicado sobre la intervención en México, deba ser una guía para la gente de este país con referencias generales a los negocios mexicanos y auxiliarlos para determinar cómo deben actuar con México?

Dr. INMAN. Eso, naturalmente representa mi opinión y la opinión que espero otros tendrán.

El PRESIDENTE. ¿Fue ése su propósito al escribirlo y publicarlo en este momento?

Dr. INMAN. Ciertamente.

El PRESIDENTE. ¿Quién está pagando su publicación?

Dr. INMAN. Ha sido publicado por editores que me dan una regalía sobre los libros, si son vendidos los suficientes.

El PRESIDENTE. ¿Objeta usted a contestar si vio los editoriales en diversos periódicos, particularmente en el New York World, que declaraban que esta carta 
suya, esta carta "agitadora", fue sacada por el Consejo Presbiteriano de Misiones Extranjeras? ${ }^{3}$

Dr. INMAN. No vi tal editorial; no, señor.

El PRESIDENTE. ¿Vio usted en alguno de los periódicos alguna declaración relacionada con eso?

Dr. INMAN. Sí, señor.

El PRESIDENTE. ¿Quién es el Dr. Halsey?

Dr. INMAN. El Dr. Halsey es uno de los secretarios del Consejo Presbiteriano de Misiones Extranjeras.

El PRESIDENTE. ¿El Dr. Halsey ha hecho publicidad a alguna declaración con referencia a esta carta suya?

Dr. INMAN. ¿Alguna declaración con referencia a la carta?

El PRESIDENTE. Sí.

Dr. INMAN. No que yo sepa.

El PRESIDENTE. ¿Sabe si alguna vez negó que la carta fuera enviada con su conocimiento por el Consejo Presbiterano? Lo que contradice la declaración que usted acaba de hacer sobre lo que vio en los periódicos.

Dr. INMAN. No, señor Presidente; de nueva cuenta no me gustaría continuar con este asunto. Me parece que ha sido lo suficientemente discutido.

El PRESIDENTE. Usted dice "No". ¿Quiere decir que no sabe o que no ha visto o no tiene conocimiento de alguna negación del Dr. Halsey parecida a la que me he referido?

Dr. INMAN. Me gustaría repetir mi petición, señor Presidente, he tratado de ser lo más amable que he podido y tan abierto y franco como me ha sido posible al contestar sus preguntas, pero preferiría no discutir más este asunto de la carta.

Senador BRANDEGEE. ¿Asume usted la posición de ser el juez que decide cuándo un tema ha sido lo suficientemente discutido ante este Comité?

Dr. INMAN. Por supuesto que no; simplemente hago esa petición al Comité.

Senador BRANDEGEE. Usted ha declinado contestar algunas preguntas que yo le he hecho. ¿Declina usted contestar a la pregunta que el senador [Fall] le acaba de hacer?

Dr. INMAN. Yo hice esa petición al Comité.

Senador BRANDEGEE. Ya lo sé; hasta donde tengo entendido, la petición ha sido denegada. Si el Comité niega la petición suya de ser eximido de contestar, ¿declinaría contestar la pregunta?

Dr. INMAN. Si tengo la autoridad para hacerlo.

Senador BRANDEGEE. Usted tiene que decidir si contestará o no.

Dr. INMAN. Si eso queda en mí, entonces me rehúso a contestar.

Senador BRANDEGEE. Queda en usted el decir si se niega o no, y queda en nosotros decidir lo que haremos si usted efectivamente se rehúsa.

El PRESIDENTE. ¿Se niega a contestar esta vez?

Dr. INMAN. Sí, señor.

El PRESIDENTE. Mostrando la línea de interrogación que el Comité se prepone seguir, haré otra pregunta para los precedentes de la documentación. ¿Hizo 
usted algún esfuerzo por corregir el malentendido del público en lo referente a que su carta había sido sacada con el consentimiento del Consejo Presbiteriano de Misiones o no? Por supuesto, puede rehusarse a contestar, si así lo desea. ¿Declina contestar a eso?

Dr. INMAN. Me niego a contestar eso.

El PRESIDENTE. Por supuesto ¿Entiende usted que lo que los miembros del Comité han dicho no le garantiza a creer que puede rehusarse a contestar las preguntas con impunidad?

Dr. INMAN. Entiendo... entiendo que es sólo amabilidad de su parte el no proseguir con el asunto, y yo lo aprecio.

El PRESIDENTE. Para continuar con otra pregunta en esa misma línea. En caso de que fuese como usted testificó y que su carta salió con el consentimiento del Consejo Presbiteriano de Misiones, como ha visto en la publicación de los periódicos ¿Es cierto que el Dr. Halsey negó dicha declaración y repudiaba dicha opinión y que usted no hizo absolutamente nada por corregir esa impresión? Entonces, en su opinión, ¿estaría usted haciendo lo justo al Consejo Presbiteriano de Misiones?

Dr. INMAN. Ciertamente, el Dr. Halsey nunca ha negado que la carta salió de su oficina. Sin embargo, nunca he escuchado sobre eso.

El PRESIDENTE. Ahora usted ha regresado a la pregunta que le he formulado, y la repito. El Dr. Halsey negó que saliera con el consentimiento o fuese emitida por el Consejo Presbiteriano de Misiones. Esa es la pregunta que usted se ha negado a contestar. Pero ahora usted dice que el Dr. Halsey no ha negado ciertas cosas. Le repito la pregunta.

Dr. INMAN. Desconozco que el Dr. Halsey haya hecho alguna declaración al respecto.

El PRESIDENTE. ¿Conoce usted al Dr. Teeter?

Dr. INMAN. Sí, señor.

El PRESIDENTE. ¿Quién es?

Dr. INMAN. El Dr. Teeter es un misionero metodista que se encontraba en Chile, o fue un misionero metodista allá, y recientemente ha estado a cargo del movimiento de formación de la Iglesia Metodista en América del Sur.

El PRESIDENTE. ¿Es un hombre de buen carácter?

Dr. INMAN. Me parece que sí.

El PRESIDENTE. Dice que así le parece. ¿Tiene alguna duda al respecto?

Dr. INMAN. No.

El PRESIDENTE. Entonces, en su opinión, él es un hombre de buen carácter.

Dr. INMAN. Sí.

El PRESIDENTE. ¿Conoce usted al Dr. Fisher?

Dr. INMAN. ¿El Dr. Fred Fisher?

El PRESIDENTE. Sí, señor.

Dr. INMAN. Lo conozco. No muy bien personalmente, pero sé bastante de él.

El PRESIDENTE. ¿En dónde se encuentra?

Dr. INMAN. Él está en Nueva York.

El PRESIDENTE. ¿Tienen el Dr. Fisher o el Dr. Teeter alguna conexión con el movimiento entre iglesias?

Dr. INMAN. El Dr. Fisher sí la tiene. No sé si el Dr. Teeter la tenga. 
El PRESIDENTE. ¿Conoce usted al Dr. Farmer?

Dr. INMAN. Sí, señor.

El PRESIDENTE. ¿Tiene alguna conexión con el movimiento inter-eclesiástico en América Latina?

Dr. INMAN. Me parece que sí.

El PRESIDENTE. ¿El Dr. Teeter también tiene alguna conexión, cierto?

Dr. INMAN. No me parece que el Dr. Teeter la tenga.

El PRESIDENTE. ¿Y el Dr. Fisher?

Dr. INMAN. El Dr. Fisher, sí, señor.

El PRESIDENTE. Los Doctores Fisher y Farmer, por tanto tienen conexión con el movimiento inter-eclesiástico. ¿Ellos son igualmente hombres de buen carácter?

Dr. INMAN. Sin duda, diría que sí.

El PRESIDENTE. ¿Cuáles son las obligaciones referentes a las actividades del movimiento inter-eclesiástico en América Latina?

Dr. INMAN. Bueno, no sabía que el Dr. Farmer estuviera conectado con el movimiento hasta apenas el otro día. Me dijo que estaba haciendo un sondeo de las Filipinas para el comité inter-eclesiástico.

El PRESIDENTE. ¿Ellos tienen algún papel en la determinación de las políticas del movimiento inter-eclesiástico?

Dr. INMAN. ¿El Dr. Farmer y el Dr. Fisher?

El PRESIDENTE. Sí, señor.

Dr. INMAN. Sí, señor.

El PRESIEDENTE. ¿Lo tienen?

Dr. INMAN. Debo decir que sí.

El PRESIDENTE. ¿Qué papel tiene usted en la determinación de las políticas del movimiento inter-eclesiástico en América Latina?

Dr. INMAN. El movimiento inter-eclesiástico, me ha pedido dirigir sus sondeos en América Latina, y también publicar un periódico en español, o ser el editor de un periódico en español para expandir el movimiento inter-eclesiástico en Latinoamérica.

El PRESIDENTE. ¿Es esa su única conexión con el movimiento inter-eclesiástico en Latinoamérica?

Dr. INMAN. Bueno, estoy relacionado con las dos secciones, la sección de sondeos y la que llamada sección de campo. La sección de sondeos se encarga de estudiar las condiciones en Latinoamérica y de hacer un libro, la de campo se encarga de trabajar con la gente, miembros de la Iglesia Evangélica y otras, para hacerlos entender y cooperar con el movimiento inter-eclesiástico.

El PRESIDENTE. ¿Tienen alguna junta o comité que formula las políticas y delinea el trabajo que tiene que ser hecho por cada una de estas secciones, lo tienen?

Dr. INMAN. Hay una sección de sondeos y otra de campo, con sus respectivas secretarías.

El PRESIDENTE. ¿Al operar con o bajo estas secciones, está usted bajo el control, dirección o el consejo de alguien más o simplemente actúa como usted quiere?

Dr. INMAN. Bueno, naturalmente actuamos juntos, en cooperación. 
El PRESIDENTE. ¿Tiene usted la misma participación que cualquier otro en la definición del trabajo que se va que realizar?

Dr. INMAN. Probablemente en Latinoamérica, mi campo particular. En donde por supuesto, hay una Secretaría general, que está a cargo de todos los lugares, América Latina, China, Japón, entre otros.

El PRESIDENTE. ¿Está usted autorizado a inaugurar alguna nueva política o definir algunas nuevas políticas con referencia a su trabajo en Latinoamérica?

Dr. INMAN. Me parece que no. Si entiendo bien el significado que usted le da al término "políticas", diría que no. Verá usted, el movimiento inter-eclesiástico mundial no es un organismo ejecutivo; esto es, no es un organismo que contrata misioneros y los envía fuera; simplemente es un organismo dedicado a promover el interés y promover la recaudación de fondos para las juntas.

El PRESIDENTE. ¿Cómo opera? ¿Por medio de un comité o junta de gobierno, cómo?

Dr. INMAN. Opera por medio de lo que es llamado un comité de cien, que suma ahora aproximadamente 150 personas. Es un comité ejecutivo de aproximadamente 22 miembros, y luego un gabinete de secretarios.

El PRESIDENTE. ¿Al comité ejecutivo y unos 22 miembros es a quien usted dirigió esta carta, de la que hablábamos ayer, o no?

Dr. INMAN. No, señor.

El PRESIDENTE. ¿A quién iba dirigida?

Dr. INMAN. Estaba dirigida a los individuos que estaban presentes en la conferencia realizada en Ciudad de México, representando a las juntas misioneras. El PRESIDENTE. ¿La representación de 22 que usted acaba de mencionar es la misma junta de la que habló ayer en su testimonio, o no lo es?

Dr. INMAN. No. Realmente ese no es un comité al que mi carta fuera dirigida.

El PRESIDENTE. No estoy hablando de la carta, pero usted testificó frente a un comité ayer, según tengo entendido. Si usted no lo hizo, nos enteraremos de ello ahora. ¿Esta junta de 22 opera por sí misma o tiene un comité ejecutivo o un gabinete?

Dr. INMAN. Tiene un gabinete de secretarios contratados.

El PRESIDENTE. ¿Quién traza la política, si es que alguien lo hace, que siguen los 22 ?

Dr. INMAN. El Dr. S. R. Taylor es el secretario general.

El PRESIDENTE. ¿El secretario delinea la política a seguir?

Dr. INMAN. Supongo que es a él a quien se recurre más que a nadie para eso.

El PRESIDENTE. ¿En su carta, la que discutíamos ayer, trazar una política o intentar ajustar lo seguido por cierta política, era simplemente su propia política o la de sus socios?

Dr. INMAN. La carta sólo me representaba a mí.

El PRESIDENTE. ¿Consultó usted a alguno de sus socios antes de enviar dicha carta?

Dr. INMAN. Me parece que no lo hice.

El PRESIDENTE. ¿Quiere que nosotros pensemos que usted simplemente se sentó y dictó esa carta y la envió usted mismo sin consultar con nadie?

Dr. INMAN. Sí, señor. El Dr. Winton sugiere que usted no distingue entre el movimiento inter-eclesiástico mundial, que es de muy reciente origen, y este 
comité más antiguo al que he estado asociado por varios años, el Comité de Cooperación con América Latina, que es una organización permanente que representa diversas delegaciones. Admito que hay relaciones complicadas allí y que es difícil de comprender.

El PRESIDENTE. ¿Qué es ese antiguo Comité permanente sobre Latinoamérica? ¿Cuántos miembros constituyen dicho comité?

Dr. INMAN. Está conformado por un representativo de 30 delegaciones diferentes.

El PRESIDENTE. ¿Entonces, hay 30 representantes, de acuerdo?

Dr. INMAN. Sí; y algunos otros miembros cooperadores, llegando a contabilizar 32 o 34 en total.

El PRESIDENTE. ¿Están representados por el comité en turno o por un secretario, o qué, y cómo operan?

Dr. INMAN. Operan con un comité ejecutivo de aproximadamente 12 miembros, y después el Dr. Winton y yo somos los dos secretarios que dedican todo su tiempo al trabajo.

El PRESIDENTE. ¿Consultó al Dr. Winton antes de enviar esta carta?

Dr. INMAN. No; el Dr. Winton estaba en Nashville.

El PRESIDENTE. Usted declaró ayer que tenía una carta que pretendía registrar. ¿Tiene el original o una copia de esta carta ahora en su posesión?

Dr. INMAN. Sí, señor; está en estos documentos [señalando documentos].

El PRESIDENTE. ¿Me la permitiría un momento, por favor?

Dr. INMAN. Me parece que después de que usted me mostró su copia ayer por la noche, la saqué... No, aquí está [presentando un documento mecanografiado]. El PRESIDENTE. ¿Es esta una copia correcta?

Dr. INMAN. Sí, señor.

El PRESIDENTE. Dice en el membrete "La sección estadounidense del Comité de Cooperación en Latinoamérica, representando a las delegaciones misionales estadounidenses y canadienses que trabajan en Latinoamérica, 25 Madison Avenue, Nueva York.

Funcionarios: Robert E. Speer, D. D., presidente; Obispo William Cabell Brown, D.D., vicepresidente; Samuel G. Inman, secretario ejecutivo; Webster E. Browning, D. D., Ph. D., secretario educacional; George B. Norton, D. D., secretario editorial; James H. Post, tesorero; E. T. Coulton, presidente del comité de sondeos; Henry C. King, D. D., LL. D., presidente del comité de educación; Gilbert N. Brink, D. D., presidente del comité de literatura; Edmund F. Cook, D. D., presidente del comité en la base de operaciones; E. E. Olcott, presidente del comité de finanzas. Comité Ejecutivo: John R. Mott, LL. D.; señorita Margaret E. Hodge; Frank Mason North, D. D.; T. B. Ray, D. D.; S. H. Chester, D. D.; E. H. Rawlings, D. D."

Oficina del secretario ejecutivo, 25 Madison Avenue, New York City. Dirección temporal de telégrafo: "Estudiante"; teléfono, Madison Square 98090.

Y aquellos cuyos nombres ya he leído, aparecen marcados con un asterisco. ¿Dice usted que esta era una carta privada?

Dr. INMAN. Sí, señor.

El PRESIDENTE. ¿Firmada por usted personalmente?

Dr. INMAN. Sí, señor. 
El PRESIDENTE. Y, por supuesto, el hecho de que su nombre aparezca como el secretario ejecutivo de este comité de cooperación en Latinoamérica, a su juicio, no conlleva ningún peso adicional, en lo concerniente al contenido de la carta. Dr. INMAN. No más, que el que mi nombre conlleva.

EIPRESIDENTE. En otras palabras, su posición oficial ¿no añadiría absolutamente nada a la importancia que las iglesias, o las personas comprometidas con el trabajo cristiano en este país, le darían a cualquier documento?

Dr. INMAN. No, señor; no vinculado con esa carta, donde todos los hombres me conocían muy bien, todos aquellos a los que fue enviada me conocían bien.

El PRESIDENTE. Estos hombres a los que usted dice que fue enviada ¿no tendrían ningún derecho de asumir que esta carta, estando escrita bajo este membrete, hubiera sido mostrada a ninguno de los otros funcionarios o miembros de los comités que son listados en el membrete mismo?

Dr. INMAN. No, señor.

El PRESIDENTE. ¿Conoce, en términos generales, qué trato se le dio en la prensa y en las publicaciones periódicas del país?

Dr. INMAN. No lo sé.

El PRESIDENTE. Llamo su atención sobre un artículo que está puesto en relieve, que me fue señalado por el consejo del Comité. ¿Piensa que el artículo se refiere a esta carta suya? [Entrega al testigo un artículo subrayado].

Dr. INMAN. (Después de examinarlo). Probablemente así sea.

El PRESIDENTE. ¿Entonces estas son noticias para usted? Me refiero al contenido en este artículo en el que su carta, habiendo sido enviada como lo fue, esté catalogada en el Boletín Literario como un reportaje difundido por la junta de misiones extranjeras de la Iglesia Presbiteriana?

Dr. INMAN. Vi esto en el New York Times.

El PRESIDENTE. Bueno, entonces ¿lo corrigió en el New York Times?

Dr. INMAN. No, señor.

El PRESIDENTE. ¿Tomó algunas medidas para hacerlo?

Dr. INMAN. No, señor; no sé si la Junta Presbiteriana lo difundió o no. Supuse que ellos lo habían hecho.

El PRESIDENTE. ¿Todavía piensa que fueron ellos los que lo difundieron?

Dr. INMAN. La explicación que me fue dada es que la Secretaría se lo dio al movimiento presbiteriano Nueva Era.

El PRESIDENTE. ¿Qué Secretaría?

Dr. INMAN. Supuse que la junta presbiteriana la había difundido, basándome en lo que los periódicos decían. El Dr. Halsey, afirmó que hay cosas que se deben hacer, todo lo que podamos hacer para contrarrestarla. Tanto a él como a mí, nos sorprendió que ellos la hubieran difundido.

El PRESIDENTE. ¿No sabe nada que se oponga a esta suposición ahora?

Dr. INMAN. Sólo sé que el Dr. Halsey la entregó al departamento de publicidad del movimiento Nueva Era de la iglesia presbiteriana, pero sin suponer que ellos difundirían la carta; sólo como una información privada. Hay alguien que entregó la carta a la prensa.

El PRESIDENTE. ¿Entonces usted entiende que es sabido que esta carta fue difundida por la junta de misiones extranjeras de la Iglesia Presbiteriana?

Dr. INMAN. Tengo entendido que fue difundida por el movimiento Nueva Era. 
El PRESIDENTE. Veamos si podemos descubrir quién conforma o constituye el movimiento Nueva Era. ¿Quiénes están a la cabeza del movimiento Nueva Era? Dr. INMAN. No estoy muy familiarizado con eso. Es una organización totalmente presbiteriana, pero es como el centenario metodista y esos otros movimientos que representan a toda la denominación religiosa en su conjunto.

El PRESIDENTE. Entonces, según su información ¿esta carta suya ha sido endosada por el movimiento Nueva Era, que es un movimiento acogido por la junta Presbiteriana?

Dr. INMAN. Acogido por la Iglesia Presbiteriana.

El PRESIDENTE. Bueno, acogido por la Iglesia Presbiteriana, que tiene el endoso del movimiento Nueva Era de la Iglesia Presbiteriana.

Dr. INMAN. Por lo menos ellos fueron los que la difundieron.

El PRESIDENTE. ¿Ellos fueron los que la difundieron y ellos son los responsables, si ellos lo sacaron como un reportaje?

Dr. INMAN. Sí, diría que ellos son los responsables del mismo.

El PRESIDENTE. Entonces, si hay alguna responsabilidad por la difusión de este reportaje, en lo concerniente a la prensa, ¿se atribuye a la Junta de la Iglesia Presbiteriana o al movimiento Nueva Era de esa iglesia?

Dr. INMAN. Bueno, ése fue el modo en que la carta llegó a la prensa.

El PRESIDENTE. Le estoy haciendo una pregunta. Usted afirma no ser responsable de su publicación, que sólo la endosó como una pieza de información privada. Entonces, si fue endosada por alguien, o se publicó por alguna imposición - porque usted ni siquiera la escribió en su calidad de funcionario y no la endosó en su carácter de funcionario-habría alguna sanción oficial. ¿Sería a la Iglesia Presbiteriana, a través de su movimiento Nueva Era?

Dr. INMAN. Estoy dispuesto a que usted haga su propia interpretación.

El PRESIDENTE. Le estoy preguntando cuáles son los hechos. Yo no sé nada al respecto.

Dr. INMAN. Bueno, yo tampoco. No sé exactamente en dónde recaería la responsabilidad en este caso.

El PRESIDENTE. Por lo menos, usted mismo está dispuesto - a pesar de que ésta era una carta privada, sin intención de ser publicada, que no fue entregada a ninguno de sus socios encargados de dirigir la política de trabajo con la que usted estaba comprometido, meramente era privada y personal comunicación suya- a verla expuesta al público en el New York Times y otros periódicos. Así como artículos similares a éste, que acaba de leer en el Boletín Literario del 30 de agosto, como un reportaje de la junta de misiones extranjeras de la Iglesia Presbiteriana. ¿Está dispuesto a que eso sea publicado y no corregirlo, ni aquí ni en ningún lado?

Dr. INMAN. No pienso que sea mi asunto el corregirlo. De ningún modo.

El PRESIDENTE. Usted hablaba ayer de propaganda. Tengo aquí el Collier's Magazine del 13 de septiembre, con un artículo "El lío mexicano", por William Slavens Mcnutt. ¿Revisaría el artículo y nos daría su opinión sobre éste?

Dr. INMAN. (Después de examinar el artículo). Yo no aceptaría esta declaración. El PRESIDENTE. ¿Lo voltearía y lo observaría detenidamente? Ese artículo es bastante extenso y algunas de sus partes están marcadas. 
Dr. INMAN. (Después de un examen detallado). Por supuesto que no concuerdo con eso, Señor Senador.

El PRESIDENTE. Bueno, ¿por qué concuerda con él, Doctor?

Dr. INMAN. Porque no creo en las afirmaciones que el autor hace allí. Por ejemplo:

Un carrancista, usted verá, es un mexicano que milita temporalmente bajo la bandera de Carranza. Tengo muchos amigos como el General Gregorio Osuna, de quien sé es un hombre perfectamente leal y desinteresado como los hay en todos lados, quienes están entregándose a esa causa porque creen en ella.

Después esta declaración: Carranza no podría viajar dentro de su propio país; no se atrevería a moverse fuera de la Ciudad de México. Recientemente él realizó un viaje extenso por todo México, y sale de la Ciudad de México muy seguido; viaja siempre que lo desea.

El PRESIDENTE. ¿Con alguna dirección específica?

Dr. INMAN. Bueno, este último viaje, según recuerdo, fue rumbo a Jalisco. El viaje anterior a ése fue a la inquieta región de Morelos.

El PRESIDENTE. ¿Viaja con una guardia o no?

Dr. INMAN. Supongo que tiene un tren militar que va delante de él. La mayoría de los trenes de pasajeros tienen una guardia en estos tiempos.

El PRESIDENTE. ¿Y hay soldados con él en el tren?

Dr. INMAN. Supongo que sí.

El PRESIDENTE. ¿Y hay un tren militar con él?

Dr. INMAN. Puede ser; no sé acerca de eso.

El PRESIDENTE. De hecho ¿sabe usted que actualmente no viaja fuera de la Ciudad de México sin tropas a su lado?

Dr. INMAN. Juzgo que debe de ser así, señor.

El PRESIDENTE. ¿Bueno, lo sabe o no?

Dr. INMAN. No tengo pruebas de ello. No recuerdo ninguna declaración.

El PRESIDENTE. ¿Si no tiene pruebas, cómo puede negar el escrito del señor McNutt?

Dr. INMAN. Dije que no lo creía.

El PRESIDENTE. ¿Pero usted cree que Carranza puede viajar sin necesidad de llevar un tren militar frente a él, ni tropas en su propio tren, ni con otro tren con tropas siguiéndolo detrás?

Dr. INMAN. Bueno, sé que hizo un viaje la primavera pasada.

El PRESIDENTE. ¿Usted sabe eso por propio conocimiento?

Dr. INMAN. Sí, señor.

El PRESIDENTE. ¿Usted sabe cómo viajó, por propio conocimiento?

Dr. INMAN. No, no lo sé.

El PRESIDENTE. ¿No lo sabe?

Dr. INMAN. No lo recuerdo. Simplemente lo sé por medio de la prensa. Fue extensamente informado.

El PRESIDENTE. Bueno, ¿Le interesaba dar información Doctor fuera de lo que vio en la prensa, o no? ¿Es esa la idea? Casi todo lo que ha testificado hasta ahora, se refiere a la prensa o algún extracto periodístico. ¿Es esa la fuente de su información con respecto a los asuntos de América Latina en general? ¿Depende usted de la prensa para obtener información sobre los asuntos relativos a Latinoamérica en general? 
Dr. INMAN. La prensa y los libros que leo cuando viajo por el país, por supuesto, las investigaciones que hago.

El PRESIDENTE. Ahora bien, ¿cuándo fue que hizo su último viaje a México?

Dr. INMAN. Fui a finales de enero y regresé en marzo.

El PRESIDENTE. ¿Por dónde entró a México?

Dr. INMAN. Entré a México por Laredo.

El PRESIDENTE. ¿De Laredo a dónde fue?

Dr. INMAN. Al sur pasando por Monterey [sic] y Saltillo, San Luis, Aguascalientes, Zacatecas, Ciudad de México, de regreso a Saltillo, y Piedras Negras.

El PRESIDENTE. ¿Cuánto tiempo se detuvo en los distintos lugares? ¿Hizo paradas en los diferentes lugares?

Dr. INMAN. Por lo general, tres o cuatro días.

El PRESIDENTE. ¿Cuál era el motivo del viaje?

Dr. INMAN. Iba a arreglar un congreso con las sociedades misioneras en la Ciudad de México, a la que ya he hecho referencia.

El PRESIDENTE. De acuerdo. Y al hacerlo, ¿se detuvo con el propósito de consultar con aquellos quienes iban a asistir al congreso, o con qué propósito?

Dr. INMAN. Con el propósito de recopilar información sobre el congreso. Había un grupo conmigo de secretarios delegados y misioneros, y todos los grupos se detenían en los diversos lugares que he mencionado.

El PRESIDENTE. ¿Se detuvo en las ciudades?

Dr. INMAN. Sí, señor.

El PRESIDENTE. ¿En todas? ¿Están vigiladas las vías del ferrocarril por las que usted viajó?

Dr. INMAN. Me parece que prácticamente todos los trenes llevan trenes militares delante de ellos.

El PRESIDENTE. ¿Su tren llevaba un tren militar y tropas delante?

Dr. INMAN. Sí, señor; a veces soldados en autos al frente.

El PRESIDENTE. ¿Usted no mencionó en su informe que haya hecho publicidad de este país, o sí?

Dr. INMAN. Sí, señor.

El PRESIDENTE. ¿Lo mencionó en su libro?

Dr. INMAN. No, señor; me parece que no lo hice; pero lo he declarado, señor Presidente, en mis discursos y pronunciamientos, todo el tiempo. Siempre lo he dicho.

El PRESIDENTE. ¿Que ha viajado con un tren militar frente a usted?

Dr. INMAN. Sí, señor; lo he declarado seguido.

El PRESIDENTE. ¿Sus audiencias nunca le han dado relevancia a esto cuando usted les cuenta sobre el orden y el buen gobierno de Carranza en México?

Dr. INMAN. Bueno, Senador, yo nunca he sostenido que tal orden existiese ni que no hubiera necesidad de disciplina militar o de trenes militares. He intentado abstenerme de asegurar que hay perfectas condiciones en México. Ayer dije que no creo en eso. Las condiciones están deshechas, en pedazos.

El PRESIDENTE. Doctor ¿llevó usted a sus socios, o fue solo de los pueblos a los distritos campiranos distantes de las vías férreas en ese viaje? 
Dr. INMAN. Me parece que únicamente en San Luis hicimos un viaje de distancia considerable fuera del pueblo.

El PRESIDENTE. ¿Conoció usted a los hermanos Cedillo en San Luis?

Dr. INMAN. No, señor.

El PRESIDENTE. ¿Sabe usted quiénes son? ¿Alguna vez ha escuchado de ellos?

Dr. INMAN. El nombre me suena familiar, pero no puedo recordar exactamente quiénes son.

El PRESIDENTE. ¿Qué tan lejos de San Luis fue?

Dr. INMAN. Oh, solamente unas 20 millas.

El PRESIDENTE. ¿En una misma dirección?

Dr. INMAN. Sí, señor.

El PRESIDENTE. ¿Y regresó?

Dr. INMAN. Y regresé.

El PRESIDENTE. ¿Llevó algunas tropas con usted

Dr. INMAN. No, señor.

El PRESIDENTE. ¿Vio algunas tropas en el camino?

Dr. INMAN. No, señor.

El PRESIDENTE. ¿Vio algunos bandidos?

Dr. INMAN. No, señor.

El PRESIDENTE. ¿En qué dirección fue, Doctor?

Dr. INMAN. Fui hacia el este de San Luis, a una mina donde estaban algunos estadounidenses. De hecho, yo no fui a ese viaje, según recuerdo ahora. Algunos de los otros grupos fueron allá, y yo me quedé en San Luis e hice algo de investigación.

El PRESIDENTE. ¿Durante el curso de sus investigaciones inquirió usted respecto a la tranquilidad y el orden en el estado de San Luis Potosí?

Dr. INMAN. No particularmente. Claro, mientras estábamos allí, hubo un asalto en [Real de] Catorce.

El PRESIDENTE. ¿Qué tan lejos está eso de la capital de San Luis Potosí?

Dr. INMAN. Me parece que está a 60 u 80 millas arriba de San Luis.

El PRESIDENTE. ¿Quién cree usted que dirigió ese asalto?

Dr. INMAN. No lo sé, señor, no sé quien fue.

El PRESIDENTE. ¿No conoce a alguno de los llamados líderes bandidos de México?

Dr. INMAN. No personalmente.

El PRESIDENTE. ¿Pero el nombre de los hermanos Cedillo le es un poco familiar a usted?

Dr. INMAN. Sí, señor; me es un poco familiar.

El PRESIDENTE. ¿Lo escuchó en San Luis Potosí?

Dr. INMAN. No, señor.

El PRESIDENTE. ¿O en alguna otra parte de México?

Dr. INMAN. Bueno, escuché, por supuesto, de esas cosas. Eso era dicho por diferentes personas y muy seguido en la prensa.

El PRESIDENTE. ¿Bueno, lo vio en la prensa y lo escuchó de diferentes personas?

Dr. INMAN. Ésa fue la impresión general que tuve. Supongo que esa fue la manera en que escuché de eso. Hace aproximadamente seis meses. 
El PRESIDENTE. Ahora, refiriéndonos de nuevo a este artículo sobre "el lío mexicano", por supuesto que usted no lo ha leído detenidamente, pero no concuerda con algunas de las declaraciones que se encuentran en él, dos de los cuáles han sido señalados por usted. ¿Cómo llamaría usted a ese artículo, o artículos similares, que aparecen repetidamente en los periódicos? ¿Cuál cree usted que sea el propósito de esto?

Dr. INMAN. Bueno, no lo sé. Por supuesto, supongo que este hombre quiere presentar la situación como él la percibe.

El PRESIDENTE. ¿De qué forma?

Dr. INMAN. De una forma muy oscura.

El PRESIDENTE. ¿Después de haberlo leído, cuál, a su juicio, es el propósito del artículo?

Dr. INMAN. Presentar la situación como él la ve.

El PRESIDENTE. ¿Como él la ve?

Dr. INMAN. Sí, señor.

El PRESIDENTE. ¿No la llamaría usted propaganda a favor de la intervención?

Dr. INMAN. Me parece que los artículos de ese tipo, por supuesto, tienden a hacer que los estadounidenses sientan que la intervención es necesaria.

El PRESIDENTE. ¿Y son este tipo de artículos los que usted critica por ser artículos que pretenden provocar la intervención armada en México?

Dr. INMAN. Me parece que tales artículos conducen a la gente de Estados Unidos a creer en la necesidad de la intervención armada como la única solución. El PRESIDENTE. ¿Piensa usted que ése es el propósito de este artículo?

Dr. INMAN. No lo sé. No conozco al autor ni nada acerca de él. Simplemente puede haber presentado su visión de la cuestión y tiene todo el derecho de hacerlo. El PRESIDENTE. ¿Está el artículo en la línea de lo que usted está denominando o denunciando en su literatura como propaganda intervencionista, la cual usted debe contrarrestar, la que su Iglesia debe contrarrestar?

Dr. INMAN. Bueno, la propaganda directa a favor de la intervención, por supuesto, es un asunto concreto.

El PRESIDENTE. ¿Y cuál es esa? ¿A parte del artículo escrito por un hombre llamado McDonald en el periódico de San Francisco, qué más tiene usted que siga esta línea de propaganda intervencionista?

Dr. INMAN. Señor Presidente, puedo traerle la cantidad de recortes de prensa que usted quiera y que propugnan por la intervención en México.

El PRESIDENTE. ¿Usted mismo está abogando por la intervención en México o no?

Dr. INMAN. Me refiero a la intervención armada.

El PRESIDENTE. ¿Cuál piensa usted que sea la diferencia entre una intervención armada y una guerra con México?

Dr. INMAN. Pienso que habría muy poca diferencia.

El PRESIDENTE. ¿Entonces, usted no concuerda con el Dr. Cannon en cuanto a que este país debe resistir hasta que algún motivo para la guerra se presente y entonces hacer la guerra a México?

Dr. INMAN. Sí hay un motivo real para la guerra, sí; debemos hacer la guerra. 
El PRESIDENTE. ¿Entonces, está dispuesto a dejar que las cosas sigan deslizándose como hasta ahora, con sus esfuerzos por educar a la gente, con la esperanza de evitar la guerra? ¿Ese es su propósito, cierto?

Dr. INMAN. Señor Presidente, yo no diría "que las cosas sigan deslizándose". Pienso que debemos hacer todo lo que podamos...

El PRESIDENTE. ¿Qué es lo que debemos hacer? Eso es exactamente a lo que intentamos llegar. ¿Qué es lo que los estadounidenses debemos hacer con respecto a los mexicanos o al país?

Dr. INMAN. Bueno, en primer lugar, por supuesto, me referiré a mi trabajo.

El PRESIDENTE. Claro. ¿Todos deben leer su libro primero?

Dr. INMAN. No me refiero a mi libro. Mi libro parece inquietarlo, Senador.

El PRESIDENTE. Bueno, Doctor, le diré francamente que el único problema que tengo con él es que no habla sobre los hechos reales con referencia a México, como usted ha declarado. Usted ignora completamente la historia de México y pienso que no expone los hechos de la realidad concerniente a México. Por ejemplo, no menciona que en los viajes a los que hace referencia en su libro usted, junto con sus misioneros, fueron precedidos por un tren militar armado. No se refiere a eso para nada. Aparentemente, en lo que concierne a su libro, todo era tranquilo y sereno, y usted hizo ese viaje sin que hubiera ninguna posibilidad de que apareciera algún peligro. No hace ninguna referencia a los trenes militares armados.

Dr. INMAN. ¿Puedo ver una copia del libro?

El PRESIDENTE. Sí, señor.

Dr. INMAN. Le mostraré que sí hago referencia a esas condiciones.

El PRESIDENTE. Precisamente hemos compendiado ese libro y si usted tiene otra copia puede usar ésa.

Dr. INMAN. Yo le dejé una copia aquí ayer.

El PRESIDENTE. No sé dónde está la otra ahora. Mientras busca el pasaje, le pregunté ayer sobre las condiciones en la costa oeste, y llamé su atención sobre un escrito que, por supuesto, como usted sabe, no hubiera podido ser publicado a menos que fuera un escrito amable. También le hice algunas preguntas sobre la ciudad de Guaymas y su civilización. Usted comparaba esa civilización con la civilización que tenemos aquí, y parece que usted no entiende nada acerca de la historia de los asentamientos. Usted parece pensar que Guaymas se encontraba en la región Yaqui.

Dr. INMAN. Aquí está un pasaje de mi libro.

Senador BRANDEGEE. ¿En qué página está?

Dr. INMAN. Página 175: "Los estadounidenses reconocieron como el peor elemento en la situación, la corrupción de los funcionarios menores del gobierno, y especialmente entre los numerosos generales del ejército y la organización militar, en sus tratos con la gente. Están dispuestos a admitir que probablemente ha sido imposible para el presidente Carranza eliminar a estos elementos indeseables por la posibilidad de que éstos se voltearan en su contra, y en ese caso perdería más terreno del que podría ganar. Hay un lugar en el que señalo la corrupción y cito un editorial que criticaba fuertemente a esos generales.

El PRESIDENTE. ¿Cita usted algunos casos particulares de corrupción por parte de Carranza, alguno de sus socios o generales? 
Dr. INMAN. No, señor; no cito ningún caso particular.

El PRESIDENTE. ¿Pero sí lo hace cuando se refiere a la administración de Díaz, o no?

Dr. INMAN. Sí, señor.

Senador BRANDEGEE. ¿Usted no cita esos ejemplos de corrupción entre los subordinados o los generales del ejército para indicar los peligros de viajar sin protección militar, cierto?

Dr. INMAN. No, señor.

Senador BRANDEGEE. Esa fue la pregunta que le hizo el Senador, y usted dijo que en su libro sí hacía referencia a eso.

Dr. INMAN. Bueno, hago referencia al abuso de los militares.

Senador BRANDEGEE. No; eso no fue lo que le preguntó. Le preguntó si era necesario tener protección armada para poder viajar. ¿Menciona algo de eso en su libro?

Dr. INMAN. Me parece que no digo nada acerca de eso en mi libro. Como digo, lo he mencionado en discursos muchas veces.

El PRESIDENTE. Entonces, en lo que concierne a su libro, con referencia a esta reunión de sus misioneros en la Ciudad de México, usted declaró ayer que esta reunión de misioneros se llevó a cabo por misioneros provenientes de todas partes de la república, y en ese momento usted no declaró nada acerca de la necesidad de que su tren fuese vigilado o precedido por un tren militar, y no menciona nada sobre eso en su libro.

Dr. INMAN. Senador, esa fue una decisión tomada por el Congreso en su conjunto.

El PRESIDENTE. ¿Qué?

Dr. INMAN. Ayer leí una resolución explicando cómo las distintas personas habían llegado. Esa fue la resolución del Congreso y no mi trabajo personal.

El PRESIDENTE. Usted la acepto, supongo.

Dr. INMAN. Sí, señor.

El PRESIDENTE. ¿Usted la leyó y la mencionó por lo que pudiera servir?

Dr. INMAN. Ciertamente.

El PRESIDENTE. ¿Pero usted la mencionó en conexión con eso, a través de su testimonio, que era necesario que fuera precedido por un tren armado para permitirle llegar a ese Congreso?

Dr. INMAN. No, señor. Hay muchas otras cosas que no declaramos aquí porque necesariamente esas cosas tienen que ser condensadas.

Senador BRANDEGEE. ¿No fue hecha la declaración de ese Congreso de misioneros - reunidos en la Ciudad de México, provenientes de todos los lugares de donde partieron - con el propósito de mostrar que era seguro viajar a través de México desde los diferentes puntos hacia la capital? De hecho, esos delegados y ministros religiosos que asistieron al congreso en la Ciudad de México tuvieron guardias armados para protegerlos, ya fuera en trenes armados en la vanguardia o la retaguardia, o cualquier otro tipo de protección militar.

Dr. INMAN. Ya he declarado que el tren en el que yo viajaba sí lo tuvo. Senador BRANDEGEE. ¿Sabe cuál fue la situación de los otros trenes? Dr. INMAN. No, señor. Supongo que fue la misma. 
Senador BRANDEGEE. ¿Supone usted que todos tuvieron protección militar para poder llegar a la capital?

Dr. INMAN. Supongo que sí.

El PRESIDENTE. Ahora, Doctor, respecto a esta resolución y en relación con ésta, la misma resolución que usted leyó mencionaba que habían llegado sin ningún problema, sin ningún "suceso adverso".

Dr. INMAN. Suceso adverso.

El PRESIDENTE. ¿Y todavía permanece mudo respecto al hecho de que en su viaje sin ningún "suceso adverso" fue necesario tener una escolta militar? ¿No mencionó la escolta militar?

Dr. INMAN. No, señor; no mencioné ninguna escolta militar.

Senador BRANDEGEE. ¿No considera usted que sea un "suceso adverso" el que los hombres tengan que ser protegidos por fuerzas armadas para poder viajar de un lugar a otro?

Dr. INMAN. No creo que el Congreso lo considerara así. Eso ha sido habitual en México desde hace largo tiempo.

Senador BRANDEGEE. ¿Quiere decir que se ha acostumbrado tanto al peligro que ya no piensa más en eso?

Dr. INMAN. Ellos para nada pensaron en eso.

Senador BRANDEGEE. ¿Y usted considera que eso es un mejoramiento en las condiciones del país?

Dr. INMAN. Por lo menos un mejoramiento de la situación en cuanto a los viajes.

Senador BRANDEGEE. ¿Quiere decir que han mejorado porque se atrevieron a viajar?

Dr. INMAN. Ellos no estaban tan nerviosos, en todo caso.

Senador BRANDEGEE. ¿Tenemos que cruzar la frontera, Senador?

El PRESIDENTE. Si lo hacemos sin duda que pediremos un tren armado.

Senador BRANDEGEE. Tenemos solamente mayoría de dos en el Senado.

El PRESIDENTE. Me parece que no iremos. Doctor ¿habló usted con las personas provenientes de El Paso para asistir al Congreso?

Dr. INMAN. Sí, señor.

El PRESIDENTE. ¿Fueron directamente por ferrocarril, por la Mexican Central Railroad, de El Paso a la Ciudad de México sin detenerse?

Dr. INMAN. No, señor; se detuvieron en el camino. Estuvieron allá arriba aproximadamente tres o cuatro semanas.

El PRESIDENTE. ¿Qué estaban haciendo?

Dr. INMAN. Estudiando el territorio de las misiones.

El PRESIDENTE. ¿Pero los trenes funcionaron sin contratiempo en enero y febrero; no hubo ninguna interrupción en las vías?

Dr. INMAN. Bajaron sin problemas desde la frontera.

El PRESIDENTE. Sí; pero que tal en la zona que circunda Parral, a cierta distancia del camino, en el trayecto de la Mexican Central por la ruta de Jiménez? Dr. INMAN. Toman y vuelven a tomar esa ciudad, así que es muy difícil decir quién la tiene.

El PRESIDENTE. Sabe lo suficiente de geografía para determinar si en esa tomas y esas recapturas de la ciudad tienen que cruzar la Mexican Central Railroad?

Dr. INMAN. Pienso que depende de dónde vienen. 
El PRESIDENTE. Bueno, suponga que vienen de Villa [sic], quien es el caballero que ha tomado el pueblo en repetidas ocasiones y recientemente cruzaban la Mexican Central para llegar allí ¿Me sigue? ¿Sabe algo sobre las condiciones generales de México o sobre la geografía de México?

Dr. INMAN. Conozco un poco acerca de la geografía de México.

El PRESIDENTE. Muy bien. ¿Ha escuchado [hablar] de Villa? ¿Usted lo menciona en esta carta?

Dr. INMAN. Sí, señor.

El PRESIDENTE. ¿Sabe si al tomar Parral, desde su lugar de reunión, tendría que cruzar la Mexican Central Railroad, o no?

DR. INMAN. Él cambia su sitio muy seguido, señor Presidente.

El PRESIDENTE. Bueno, posiblemente usted está más familiarizado con él que yo. ¿Sabe usted que cada vez quehan sido tomados Parral o cualquier pueblo a menos de 50 millas $^{4}$ de la Mexican Central Railroady cualquier otra vía de los alrededores, éstas son destruidas invariablemente?

Dr. INMAN. ¿La vía principal es destruida?

El PRESIDENTE. Sí.

Dr. INMAN. No, señor; no lo sé.

El PRESIDENTE. ¿[Los villistas] la dejan inservible tras su paso para que las guarniciones carrancistas de los pueblos cercanos que van detrás de ellos puedan ser frenados, lo sabe?

Dr. INMAN. Parral no se encuentra en la línea ferroviaria principal.

El PRESIDENTE. Estoy consciente de ese dato. ¿Sabe usted dónde está Jiménez?

Dr. INMAN. Sí, señor.

EL PRESIDENTE. ¿Sabe dónde está Torreón?

Dr. INMAN. Sí, señor.

El PRESIDENTE. ¿Sabe algo acerca de la paz general, el orden y la quietud en las regiones circundantes de las capitales o pueblos que usted ha mencionado?

Dr. INMAN. Bueno, las cosas parecen estar bastante tranquilas alrededor de Monterey, por ejemplo, y alrededor de Saltillo. No me pareció que hubiera disturbio alguno en Coahuila.

El PRESIDENTE. Usted habla del viaje que hizo allá. ¿Hace cuánto?

Dr. INMAN. No me enteré de algún problema en ese momento o de alguno actualmente.

El PRESIDENTE. ¿Qué importancia, si es que le da alguna, le otorga a la reciente proclamación del General Zuazua de que él ha restaurado el orden en esos lugares?

Dr. INMAN. Yo no vi eso.

El PRESIDENTE. ¿No lo vio?

Dr. INMAN. No, señor.

El PRESIDENTE. La noticia fue difundida, llegó por medio del cónsul y divulgada por el Departamento de Estado, publicada por $\mathrm{AP}^{5}$ y los periódicos.

$4 \quad$ Unos 64.37 kilómetros de distancia.

5 Se refiere a The Associated Press o AP, la agencia de noticias fundada en 1846 en Nueva York. 
Dr. INMAN. He estado fuera del país por algunos meses, así que hay muchas cosas que no leí sobre México.

El PRESIDENTE. Entonces, cuando usted escribía sus cartas y pretendía influir en Estados Unidos en contra de una intervención armada, por medio de sus juntas y todo eso que llevaba a cabo como propaganda, sus llamados al desorden ¿Tuvo referencia delo mencionado en artículos como el de McNutt en el Collier's Weekly o escritos similares referidos a México y a las condiciones del país?

Dr. INMAN. Por supuesto que no tuve referencias porque no había visto los artículos hasta que usted me los mostró.

El PRESIDENTE. Bueno, ahora ya lo ha leído. ¿Está dentro de la línea de propaganda de la que usted habla?

Dr. INMAN. No; no es la propaganda directa pro intervencionista que se ha realizado en diferentes partes del país.

El PRESIDENTE. ¿Lo ha leído todo?

Dr. INMAN. No, señor; simplemente leí las partes subrayadas.

El PRESIDENTE. ¿Está usted familiarizado con la propaganda periodística que se hace en México?

Dr. INMAN. ¿En México?

El PRESIDENTE. Sí, señor.

Dr. INMAN. Bueno, estoy algo familiarizado con los periódicos de allá.

El PRESIDENTE. ¿Lo está?

Dr. INMAN. Sí, señor.

El PRESIDENTE. ¿En su testimonio se refiere usted a los periódicos de allá que son amigables con los Estados Unidos, o no?

Dr. INMAN. Sí, señor.

El PRESIDENTE. ¿Mencionaría usted el nombre de esos periódicos?

Dr. INMAN. Bueno, El Universal.

El PRESIDENTE. ¿Quién es el editor de El Universal, Palavicini?

Dr. INMAN. Sí, señor. Y El Excélsior.

El PRESIDENTE. ¿Desde cuándo han sido favorables a Estado Unidos y a los estadounidenses?

Dr. INMAN. Me parece que el señor Palavicini siempre ha sido favorable a Estados Unidos.

El PRESIDENTE. ¿Sabe usted cuándo dejó la Ciudad de México el señor Palavicini?

Dr. INMAN. Me parece que en algún momento del año pasado.

El PRESIDENTE. ¿Recuerda usted por qué salió de la Ciudad de México?

Dr. INMAN. Escuché una o dos historias sobre eso.

El PRESIDENTE. Compártanos una de ellas.

Dr. INMAN. Bueno, una de ellas era que él criticaba ferozmente a los generales Obregón y González [sic], y al elemento militar.

El PRESIDENTE. ¿Por qué? ¿Cuál era su crítica?

Dr. INMAN. No recuerdo los detalles pero asumo que siguió la línea de que los militares estaban teniendo demasiada autoridad y que los poderes civiles debían desplazarlos.

El PRESIDENTE. Sí, señor. ¿Cuál fue otra de las historias? 
Dr. INMAN. La otra era que había una influencia pro-alemana en el gobierno mexicano que lo obligó a salir del país.

El PRESIDENTE. ¿La historia era que El Universal era pro-aliados y proEstados Unidos?

Dr. INMAN. Sí, señor.

El PRESIDENTE. ¿Y que los otros periódicos en México eran pro-alemanes y que Palavicini fue obligado a salir del país por lo mismo?

Dr. INMAN. Bueno, algunos de ellos eran pro-alemanes.

El PRESIDENTE. Le estoy preguntando sobre los relatos. Usted dijo que había una o dos historias acerca de la salida de Palavicini de México. Le pregunté, desde cuándo esos otros periódicos se habían vuelto pro-estadounidenses.

Dr. INMAN. Me parece que, en gran parte, desde la guerra.

El PRESIDENTE. Exactamente. Desde el armisticio en noviembre ¿No es así?

Dr. INMAN. Me parece que eso lo declaré ayer.

El PRESIDENTE. No recuerdo que lo haya hecho, esa ausencia me causó tal impresión por lo que me propuse hacerle la pregunta esta mañana, por esa razón se lo estoy preguntando ahora.

Senador BRANDEGEE. ¿Considera usted que estas críticas a la milicia contenidas en El Universal están justificadas?

Dr. INMAN. Nunca vi esas críticas.

Senador BRANDEGEE. ¿Considera usted que el artículo del señor McNutt, del Collier's Weekly, al que se ha hecho referencia aquí, presenta una imagen justa de las condiciones en México?

Dr. INMAN. No, señor.

Senador BRANDEGEE. ¿Piensa usted que el desorden representado en el artículo es exagerado?

Dr. INMAN. Me parece que sí.

Senador BRANDEGEE. ¿Piensa usted que es una imagen falsaen términos general?

Dr. INMAN. Me parece que representa erróneamente las condiciones expuestas. Senador BRANDEGEE. Por supuesto, entonces es falso. En su opinión, ¿es una imagen tramposa de las condiciones?

Dr. INMAN. En mi opinión; sí, señor.

El PRESIDENTE. ¿Conoce usted de los hermanos Müeller de la Ciudad de México?

Dr. INMAN. Sí, señor; sólo por la reputación relacionada con su negocio.

El PRESIDENTE. ¿Cuál es su negocio?

Dr. INMAN. Según recuerdo, ellos anunciaban cajas fuertes.

El PRESIDENTE. ¿Sabe usted si publicaban un periódico en español durante la guerra?

Dr. INMAN. No, señor; no lo sé.

El PRESIDENTE. ¿No lo sabe?

Dr. INMAN. No, señor.

El PRESIDENTE. ¿Sabe usted que había dos periódicos publicados en español durante la guerra, diseminados por todo México y enviados a través de comerciantes minoristas para ser distribuidos de manera gratuita a sus compradores? ¿Lo sabía? 
Dr. INMAN. No, señor.

El PRESIDENTE. ¿Sabía usted que estos periódicos eran pro-alemanes, editados en español por los alemanes y difundidos en todos los distritos alejados de Ciudad de México?

Dr. INMAN. No sé de esos específicamente. Me parece que uno de ellos se llama Sinalambrica.

El PRESIDENTE. Bien ¿Qué sabe sobre ése?

Dr. INMAN. Era extremadamente pro-germano, era editado por los alemanes, según tengo entendido para encausar el parecer de México.

El PRESIDENTE. ¿Cómo se le hacía circular, Doctor?

Dr. INMAN. Vi copias en la Ciudad de México y me parece que también en otras ciudades. Creo que tenía una amplia circulación general.

El PRESIDENTE. De hecho, con referencia a las críticas contra González y Obregón, que mencionó hace unos momentos, aquellas aparecieron en $\mathrm{El}$ Heraldo, más que en El Universal ¿Cierto?

Dr. INMAN. ¿Quiere decir recientemente? Yo me refería al...

El PRESIDENTE (interrumpiendo). En cualquier momento.

Dr. INMAN (continuando). Me refería al momento cuando Palavicini se fue de la ciudad...

El PRESIDENTE (interrumpiendo). ¿Por qué razón Palavicini criticó a Gonzalez, a Obregón, a los militares?

Dr. INMAN. Supongo que fue porque pensó que era el momento para que México instaurara un gobierno civil en lugar de uno militar. Los periódicos critican a los militares todo el tiempo, por lo menos me parece uno de los mejores indicios de promesa de un gobierno democrático, el que se permita a los periódicos criticar a los militares de tal modo. En otros tiempos, no se les era permitido. Este artículo de Palavicini no se hubiera autorizado en la época de Díaz o, digamos, en los días de A, B, C, que se oponía notablemente a Carranza en todo momento, ${ }^{6} \mathrm{y}$, a pesar de eso, no fue suprimida [la libertad de expresión]. En este sentido es una de las pruebas que demuestra que el gobierno de Carranza está realmente empeñado en tener libertad de prensa.

El PRESIDENTE. Ayer le leí la Constitución mexicana en lo referente a la libertad de prensa ¿No lo hice? La parte concerniente a propaganda allá en...

Dr. INMAN. Bueno...

El PRESIDENTE (interrumpiendo) ¿Usted llama a eso libertad de prensa?

Dr. INMAN. Si teóricamente lo es o no, en la práctica sí lo es, porque los archivos documentales de nuestra Iglesia demostrarán que han atacado arduamente a las autoridades.

${ }_{6}$ Se refiere al grupo ABC (Argentina, Brasil, Chile), calificado por Carranza como intervencionista en los asuntos de México, en el caso de aceptar la incitación del abogado conservador Robert Lansing (1864-1928), Secretario de Estado durante la presidencia de Woodrow Wilson entre 1915 y 1920. El propósito era que las facciones revolucionarias aceptaran la mediación de Estados Unidos y bajo el discurso del Panamericanismo, algunas naciones latinoamericanas fungieran como testigos para finiquitar las acciones bélicas, crear un gobierno provisional de coalición e impedir la venta de armas a los ejércitos de Villa 
El PRESIDENTE. ¿Eso es, a su juicio, una protección constitucional a la libertad de prensa? Leeré el artículo 130:

"Ninguna publicación periódica, ya sea por razón de su programa, su título o simplemente por sus tendencias generales y sea de carácter religioso, deberá hacer comentarios sobre cualquier asunto político de la Nación o publicar cualquier tipo de información relativa a las acciones de las autoridades del país o de individuos privados que tengan que ver o estén inmiscuidos en asuntos públicos".

¿Es esa la protección constitucional a las garantías de libertad de prensa, según su juicio?

Dr. INMAN. No, señor; no lo apruebo y pienso que las autoridades tampoco lo hacen, es por esto que el ordenamiento nunca ha sido promulgado como un estatuto, y tanto el presidente Carranza, como el poder ejecutivo de México, han sugerido modificaciones a la Constitución, las que acabarán con esas múltiples pequeñeces contra la iglesia.

El PRESIDENTE. ¿Eso lo sabe por conocimiento propio?

Dr. INMAN. Sí, señor.

El PRESIDENTE. ¿Ha tenido usted alguna conversación con Carranza sobre ese tema?

Dr. INMAN. Sí, señor; he tenido una extensa conversación con Carranza sobre el tema.

El PRESIDENTE. ¿Cuál fue la dirección que siguió esa conversación?

Dr. INMAN. Bueno, la directriz de la conversación fue que el gobierno mexicano estaba encantado de tener trabajo misionero en el país, de misioneros estadounidenses, y aquellas estipulaciones constitucionales no pretendían para nada limitar nuestro trabajo. Tan pronto como parezca ser el momento adecuado, él mismo, espera proponer al Congreso nacional los cambios, mientras tanto deberíamos seguir con nuestro trabajo.

El PRESIDENTE. ¿Exactamente como lo está haciendo?

Dr. INMAN. Exactamente como lo estamos haciendo.

El PRESIDENTE. Ahora bien ¿Qué están haciendo los católicos allá? ¿Están avanzando con su trabajo?

Dr. INMAN. Sí, señor.

El PRESIDENTE. ¿Y con la misma libertad?

Dr. INMAN. Sí.

El PRESIDENTE. ¿Usted sabe eso por conocimiento propio, le consta?

Dr. INMAN. Sí, señor.

El PRESIDENTE. Y nunca le fueron ofrecidos incentivos especiales allá...

Dr. INMAN (interrumpiendo). No, señor.

El PRESIDENTE. Y es simplemente por gratitud a eso que usted está realizando la propaganda pro-Carranza...

Dr. INMAN. No, señor.

El PRESIDENTE. ¿Entonces por qué lo hace?

Dr. INMAN. Simplemente porque creo que los estadounidenses deben conocer las condiciones en México.

El PRESIDENTE. ¿Y usted las está mostrando a los estadounidenses, eso cree? 
Dr. INMAN. Sí, señor; así es como lo veo, y pienso que es mi deber como un estadounidense hacer mi parte permitiendo a la gente conocer las condiciones como yo las veo.

El PRESIDENTE. ¿Y, por supuesto, usted lo hace conscientemente?

DR. INMAN. Ciertamente lo hago, en efecto.

El PRESIDENTE. ¿Pero usted no les cuenta a los estadounidenses acerca de la necesidad de llevar tropas armadas frente a los trenes que van a México?

Dr. INMAN. Sí lo hice.

El PRESIDENTE. Pero no lo ha hecho en su libro.

Dr. INMAN. Admito eso; que no lo hice en mi libro.

El PRESIDENTE. Y usted no menciona...

Dr. INMAN. No mencionó eso en mi libro; no, señor.

El PRESIDENTE. Bueno, si no lo hace en su libro ¿En dónde lo menciona?

Dr. INMAN. Se los he dicho en discursos públicos.

El PRESIDENTE. ¿En más de un discurso público?

Dr. INMAN. Sí, señor.

El PRESIDENTE. ¿Dónde?¿En qué lugar?

Dr. INMAN. Es una de las partes principales de mis discursos permanentes en México.

El PRESIDENTE. ¿Tiene usted una copia de ese discurso?

Dr. INMAN. No, señor.

El PRESIDENTE. ¿Ha escrito usted ese discurso público que ha presentado en México...?

Dr. INMAN (interrumpiendo). No recuerdo haberlo hecho. Podría encontrarlo en algunas de mis declaraciones públicas.

El PRESIDENTE. Con referencia a este artículo 130 de la Constitución mexicana, observo que no se concede juicio frente a un jurado por la infracción de alguna de las estipulaciones anteriores ¿Le dijo el señor Carranza que eso iba a ser revisado?

Dr. INMAN. No se hizo referencia alguna a esecaso en particular.

Senador BRANDEGEE. Cuando Carranza le dijo que no era propósito del artículo 130 intervenir con su trabajo ¿Mencionó cuál era el propósito del artículo?

Dr. INMAN. Bueno, como lo dije ayer, según tengo entendido, de manera general, él personalmente no estaba a favor de ese artículo.

Senador BRANDEGEE. Usted dice que no era el propósito de ese artículo [constitucional] intervenir con su trabajo. ¿Cuál era el propósito del artículo? ¿A quién representa ese artículo?

Dr. INMAN. Al gobierno; al suyo, es representación del gobierno.

Senador BRANDEGEE. ¿El gobierno no es superior a la Constitución, cierto?

Dr. INMAN. Lo es hasta que los principios constitucionales son promulgados como estatutos.

Senador BRANDEGEE. El poder ejecutivo no es superior a la Constitución, tanto si el estatuto ha sido aprobado como si no lo fue; desde su punto de vista ¿Qué intención está expresando Carranza cuando señala que el propósito del artículo [130] no era interferir con su trabajo

Dr. INMAN. La del gobierno.

Senador BRANDEGEE. ¿Quiere decir Carranza? 
Dr. INMAN. Carranza y naturalmente su gabinete y esos...

Senador BRANDEGEE (interrumpiendo). ¿Carranza argumentó o declaró de manera clara que la intención del artículo fuera diferente a lo que expresa?

Dr. INMAN. Él no entró en ese asunto. Simplemente dijo que no tenía por qué temer; que ellos no esperaban que cambiáramos para nada nuestras políticas; que reconocían la naturaleza de las fuerzas misioneras protestantes estadounidenses, y nos aconsejaba seguir adelante.

Senador BRANDEGEE. Eso quiere decir que ¿a pesar de la clara prohibición de la Constitución mexicana contra lo que usted hacía, le aconsejó seguir adelante con ello?

Dr. INMAN. En ese momento, por supuesto.

Senador BRANDEGEE. Ése es el momento del que estoy hablando.

Dr. INMAN. La Constitución no había sido aprobada...

Senador BRANDEGEE (interrumpiendo). Digo que a pesar de esos artículos constitucionales que le prohibía a usted y a sus periódicos comentar sobre los actos del gobierno y criticarlos, le dijo que siguiera adelante sin interferencia alguna de su parte...

Dr. INMAN (interponiendo). No recuerdo que Carranza se hubiera referido a ese artículo en particular, sino que simplemente lo dijo por todos los artículos constitucionales que parecían prohibir el que siguiéramos adelante con nuestro trabajo.

Senador BRANDEGEE. En otras palabras, dado que Carranza pretendía en algún momento del futuro cambiar la Constitución, él le dijo a usted que continuara y que no sería interferido en su trabajo ¿Así fue?

Dr. INMAN. Sí, señor.

Senador BRANDEGEE. ¿Sin importar cuáles artículos estaban en la Constitución?

Dr. INMAN. Sí.

Senador BRANDEGEE. Eso es todo.

El PRESIDENTE. Doctor Inman, otra disposición de la Constitución a la que, asumo, hacía referencia el señor Carranza fue al artículo $3^{\circ}$ ¿cierto?

Dr. INMAN. Sí, señor.

El PRESIDENTE. ¿Recuerda usted cuál es el artículo $3^{\circ}$ ?

Dr. INMAN. Es en referencia a la propiedad...

El PRESIDENTE (leyendo): "Ninguna corporación religiosa ni ministro de cualquier credo religioso podrá establecer o dirigir escuelas de instrucción primaria".

Ese es uno de los artículos de los que usted ha hablado con él y aseguró no tendría efecto en su contra. ¿Qué es lo que Carranza proponía hacer con ese artículo constitucional, lo sabe?

Dr. INMAN. No; no lo sé.

El PRESIDENTE. Supongo que una estipulación que llega más lejos que la del artículo 130 que:

"Ningún ministro de credo religioso alguno puede heredar, ya sea por su parte o por medio de un fideicomiso o de otra forma, ningún bien raíz en posesión de cualquier asociación de propaganda religiosa o de propósitos religiosos o de caridad. Los ministros de credos religiosos son legalmente incapaces de heredar por medio de testamentos de los ministros del mismo credo religioso o de otro 
individuo particular con los que no estén relacionados consanguíneamente hasta el cuarto grado".

¿Eso también iba a ser suspendido?

Dr. INMAN. Bueno, él simplemente hizo una referencia general a la Constitución...

El PRESIDENTE. ¡Usted entendió eso! ¿Con quién tenía estas conversaciones, además del propio Carranza?

Dr. INMAN. Tuve una conversación con el que me parece era el encargado de negocios aquí en Washington.

El PRESIDENTE. Bonillas ${ }^{7}$ es el encargado de negocios.

Dr. INMAN. Y él expresó la misma opinión. Que éste era un asunto de la administración, tal como lo he narrado.

El PRESIDENTE. Sí; en efecto es lo que usted dice aquí, en la página 8 de su libro (leyendo): "Durante la administración de Díaz algunos misioneros estadounidenses comenzaron a preocuparse por temor de estar desobedeciendo las Leyes de Reforma al sostener reuniones en casas privadas. Acudieron al presidente sobre este asunto, preguntó si habían sido molestados y ellos contestaron negativamente. "Muy bien entonces" — dijo él- "sigan con su trabajo." Si ellos hubieran insistido en obtener un fallo, la estricta interpretación de la ley hubiera estado en su contra. Pero ¿para qué preocuparse mientras las autoridades no los molestaran? ¿Ese incidente al que hace referencia ocurrió allí, así sucedió?

Dr. INMAN. Sí, señor.

El PRESIDENTE. Ahora bien ¿Por casualidad sabía usted que nosotros teníamos un tratado con México en el que se garantizaban los derechos de los protestantes para sostener reuniones en casas privadas?

Dr. INMAN. No.

El PRESIDENTE. Bueno, le puedo asegurar que Don Porfirio lo conocía.

Usted continúa[en su libro] con esta aseveración: "De la misma forma, cuando la Constitución de 1917 fue adoptada, con leyes todavía más enérgicas para controlar las actividades religiosas, los funcionarios de Carranza explicaron a los misioneros estadounidenses que podían hacer su trabajo como antes. "Es cuestión de administración" fue la explicación, lo que significaba que la estipulación debía de ser invocada en todo momento cuando una organización religiosa comenzará a inmiscuirse en asuntos políticos. ¿Es esa la verdadera clarificación de lo que ha estado tratando de explicar aquí, de acuerdo? ¿Esa es la garantía que usted obtuvo de Carranza?

Dr. INMAN. Esa fue con el encargado de negocios aquí, según recuerdo.

El PRESIDENTE. ¿Qué fue lo que le dijo Carranza?

Dr. INMAN. Que debíamos seguir adelante con nuestro trabajo y no hacer ningún cambio y que no teníamos que alarmarnos o planear el retiro de nuestros misioneros, ni nada por el estilo.

7 Se refiere al ingeniero Ignacio Bonillas Fraijo (1858-1942), diputado del Partido Antirreeleccionista, miembro del gabinete de Venustiano Carranza en 1915, embajador de México en Washington en 1917 y candidato presidencial oficialista, hasta la fatídica muerte del Primer Jefe de la Revolución en Tlaxcalantongo en 1920. 
El PRESIDENTE. ¿Quién estaba con usted al momento de tener esta plática con Carranza?

Dr. INMAN. El obispo McConnell, de la Iglesia metodista; aquí en Washington no sé quién estaba conmigo; probablemente estaba yo sólo.

El PRESIDENTE. Pero si el presidente Carranza muriera y alguien más fuera electo presidente ¿Sabe si esta disposición constitucional sería invocada en su contra o no lo sabe?

Dr. INMAN. Lo desconozco, excepto que el Congreso esté considerando un cambio.

El PRESIDENTE. ¿Un cambio en la Constitución?

Dr. INMAN. Sí, señor.

El PRESIDENTE. ¿Puede usted darnos la información con referencia a ese cambio? ¿Cuál es la modificación propuesta en la Constitución?

Dr. INMAN. Tengo esa información [pero no aquí], la puedo buscar para usted, señor presidente.

El PRESIDENTE. Sólo declare explícitamente cuál es, tan aproximado como pueda recordarlo, y yo le diré si la queremos o no.

Dr. INMAN. Lo que recuerdo es que el general Carranza o el presidente Carranza envió al Congreso nacional una propuesta para que algunos artículos constitucionales referentes a las limitaciones impuestas a estas organizaciones fueran cambiados o eliminados, para así otorgar libertad absoluta de culto en México.

Senador BRANDEGEE. Entiende usted que estas estipulaciones constitucionales - que prohíben sus actividades, a las cuales se ha referido, de las está hablando ahora y nos ha dado su opinión - ¿Pueden hacerse cumplir en su contra, en la ausencia de un reglamento?

Dr. INMAN. No tengo entendido eso, señor Senador. Me parece que debe de haber un reglamento en cada artículo para interpretar la Constitución y al menos que el Congreso haya aprobado el estatuto o exista un decreto presidencial sobre el asunto. De lo contrario no hay forma de hacer cumplir los principios de la Constitución.

Senador BRANDEGEE. ¿Usted tiene conocimiento de que el presidente de México, sin un estatuto, por la expedición de un decreto presidencial, puede hacer efectivas las estipulaciones de la Constitución?

Dr. INMAN. Bueno, es lo que él ha estado haciendo.

Senador BRANDEGEE. ¿Qué caso tiene entonces tener un reglamento?

Dr. INMAN. Por supuesto, esto es solamente lo que señala la Constitución adoptada en 1917, el Congreso discute bastante cuando se reúne, tienen enfrentamientos políticos, disputas, etcétera y promulgan leyes de manera paulatina.

Senador BRANDEGEE. ¿Sabe usted que Carranza debe hacer un juramento para respaldarla Constitución de México?

Dr. INMAN. Me parece que sí.

Senador BRANDEGEE. ¿Y luego usted dice que no la respaldará en su contra?

Dr. INMAN. Bueno, si esa es la manera en que desee que la interprete... 
Senador BRANDEGEE. Yo sólo quería llegar a los hechos sobre ese asunto, para descubrir si Carranza pone en marcha la Constitución o hace lo contrario. No me parece un gobierno muy correcto y estable ¿Comprende lo que digo?

Dr. INMAN. Yo mismo no lo creo. Hay muchas cosas en las que no concuerdo con él.

Senador BRANDEGEE. ¿Pero prácticamente está usted bajo sus órdenes en lo que concierne a la realización de sus operaciones en México?

Dr. INMAN. Supongo que en cualquier momento puede detenernos.

Senador BRANDEGEE. Usted quería averiguar qué clase de posición ocupaba en México y sostuvo conversación con Carranza ¿Obtuvo garantía personal para poder quedarse allá?

Dr. INMAN. Sí, señor.

El PRESIDENTE. Muy bien, Doctor, estoy muy agradecido con usted.

Dr. INMAN. Bien señor, yo estoy agradecido con ustedes caballeros. ¿Podría tomar cinco minutos de su tiempo? Tengo un mapa que me gustaría que vieran como algo ilustrativo de lo que intentamos hacer allá.

El PRESIDENTE. Estaríamos encantados de verlo. Sin embargo, no podemos incluir este mapa en el registro, así que sólo podemos verlo para la información de este comité.

Dr. INMAN. Por supuesto. Este mapa coloreado representa la división de responsabilidades de las diferentes juntas misionales que se encuentran actualmente operando en México. Hace aproximadamente cinco años comenzamos a estudiar de manera más científica la distribución del trabajo y cómo podríamos mejorarla. Por ejemplo, en ese momento teníamos en Tampico tres grandes escuelas protestantes para niñas...

El PRESIDENTE. ¿Cuándo fueron establecidas? Sólo mencione su fundación, la fecha de su establecimiento.

Dr. INMAN. Una de ellas fue establecida hace 30 años aproximadamente y otra hace 25 años, todas fundadas hace más de un cuarto de siglo.

El PRESIDENTE. ¿Fueron establecidas antes de la Revolución?

Dr. INMAN. Sí, señor. Descubrimos que en los estados (señalando) como Michoacán, con su capital de 35,000 o 40,000 [habitantes], y el total de la entidad michoacana con una población de 1,000,000 de habitantes no contaba con trabajadores evangélicos. Encontramos condiciones de alta aglomeración por un lado y falta de misioneros por el otro [por lo que] la junta misional decidió realizar una distribución científica de sus responsabilidades, así como permutar su labro en esos territorios. El resultado fue la expansión actual del trabajo de la junta Presbiteriana que cubre desde Sonora hasta Yucatán, y la Iglesia Metodista también extendió su trabajo desde el norte hasta el sur del país. Ellos decidieron desocupar ese estado, Michoacán, "abandonando gran parte de nuestro viejo territorio, para poder asegurarnos que cada parte de México esté ocupada con trabajo misional". Esto me parece una manera notable en la historia misionera que se ha llevado a cabo desde el año pasado. Por ejemplo, los presbiterianos sureños hicieron su trabajo por aquí [señalando en el mapa].

El PRESIDENTE. "Por aquí" no indica nada en este registro.

Dr. INMAN. Me refiero al trabajo en Tamaulipas que ha cambiado para atender Morelos y Michoacán; y la junta metodista sureña salió de la Ciudad de México 
y San Luis [Potosí] y se ha ocupado de esta otra porción del territorio, los estados de Nuevo León, Coahuila y otros dos, Baja California y Sonora. Aunque para ser precisos Sonora, Sinaloa, Nayarit y Jalisco son el territorio de la junta congregacional, antes estuvieron en Chihuahua, pero se han ido de allí y han concentrado sus asuntos por completo en aquel extremo [señalando en el mapa]. Los discípulos desarrollan su labor aquí [señalando en el mapa], o la tuvieron en Coahuila, y han mudado sus afanes en favor de los metodistas trasladándose a Zacatecas, San Luis, y Aguascalientes. Por su lado, los presbiterianos del norte, han dejado su labor en toda la Ciudad de México para avanzar hacia el sur, a Veracruz, Oaxaca, Tabasco, Chiapas, Campeche, Quintana Roo y Yucatán. Estalabor ha estado acompañada, no sólo de un programa para cada una de las sociedades misioneras, sino también por un programa unificado para todas.

Antes de que este arreglo se hiciera efectivo se publicaban como ocho periódicos misioneros, organizados por las diferentes sociedades. Todos se han consolidado en una sola prensa, en la Ciudad de México, y en ese periódico se dispone, actualmente, un gran beneficio para el país. Se cuenta con un proyecto para erigir una universidad en la Ciudad de México — no una universidad propiamente en sentido estricto, pero probablemente similar al Hampton Institute, o algo parecido- que deberá formar a los jóvenes para el trabajo en las industrias, capacitarlos para convertirlos en maestros que vayan a los distritos rurales para educar a los jóvenes en el trabajo manual. Asimismo, está planeado un gran hospital en la Ciudad de México, y otros hospitales que serán distribuidos en otras ciudades. El plan incluye también la organización de ocho escuelas agrícolas, una para cada una de estas juntas misionales. Esperamos ser capaces de ayudar de inmediato y rápidamente con la solución del problema de la tierra. El PRESIDENTE. ¿Dónde estarían esas escuelas?

Dr. INMAN. Una estará, no, corrijo, ya está establecida en Tamaulipas, otra estará en Chihuahua, y una en San Luis [Potosí], además de Aguascalientes, Michoacán y Yucatán...

El PRESIDENTE (interrumpiendo). ¿Hay algunas escuelas de agricultura actualmente en México?

Dr. INMAN. Sí, señor; hay una sostenida por el gobierno.

El PRESIDENTE. ¿En dónde?

Dr. INMAN. En la Ciudad de México. ${ }^{8}$

El PRESIDENTE. ¿Es la única?

Dr. INMAN. Esa es la única que conozco, excepto, por supuesto, el trabajo misional, como el de los "Amigos", que tienen un par de granjas.

El PRESIDENTE. Me refiero a escuelas públicas de agricultura o universidades gubernamentales, urbanas o municipales.

Dr. INMAN. Yo sólo sé de la que está cerca de la Ciudad de México.

8 En realidad, se encontraba en Chapingo, en el Estado de México, la Escuela Nacional de Agricultura y Veterinaria (1907), también es probable que se refiera a la Escuela de San Jacinto, en el pueblo de San Ángel, perteneciente a la Ciudad de México al iniciar el siglo xx, cuyos profesores y alumnos establecieron las primeras estaciones experimentales de carácter agrario entre 1908 y 1910. 
El PRESIDENTE. Pensé que había dos en el estado de Chihuahua. ${ }^{9}$

Dr. INMAN. Tendremos esas escuelas agrícolas en cada uno de los centros [que fundemos]. En cada uno planeamos tener una especie de escuela de oficios y centro social donde la gente de México pueda aprender oficios y, al mismo tiempo, tener un lugar de reunión para discutir sus problemas cívicos y sociales, muy cercano a lo que ha hecho nuestra democracia, en donde hemos podido reunirnos en las antiguas juntas del ayuntamiento para discutir nuestros asuntos. No hay esos espacios de discusión en México, y las juntas misionales están interesadas en ese tipo de servicios en las comunidades y después, por supuesto, tenemos nuestro trabajo evangélico directo con las diversas iglesias en todos los lugares de México. El programa de cooperación, como se encuentra delineado en el mapa, muestra una universidad y un hospital en la Ciudad de México, las escuelas de agricultura que mencioné en la mayor parte de los centros importantes de la república; además de escuela técnicas y mecánicas en cada centro industrial, escuelas normales en los distritos que no las tengan todavía, así como el fortalecimiento de aquéllas ya existentes.

El desarrollo del Union Theological Seminary ya existente en la Ciudad de México, muestra qué tanto ha significado la contribución a las instituciones evangélicas en México. Hemos formado a una gran cantidad de jóvenes, hombres y mujeres, dispuestos a ingresar a las escuelas gubernamentales, en este sentido, no sólo han sido recibidos gustosamente, sino que se nos ha dicho que tomarán a todos los maestros que podamos compartir. Éste es uno de los frenos de la educación en México, la formación de maestros. Por eso se desarrollará el Union Theological Seminary de la Ciudad de México que emprendimos hace un par de años y los primeros cinco estudiantes que aplicaron eran miembros de cinco diferentes denominaciones.

El PRESIDENTE. ¿Cuáles?

Dr. INMAN. Congregacionalista, metodista del norte y el sur, los "Amigos" [cuáqueros] y un presbiteriano.

El PRESIDENTE. ¿Y usted coopera con la iglesia católica?

Dr. INMAN. No de manera directa, por lo menos en lo que he estado hablando, pero cooperamos encantados, o cooperaremos con ellos al igual que con los movimientos temperantes, las organizaciones civiles que se ocupen de cuidar al afligido o cualquier tema relacionado. Pero, debería decir, señor Presidente, que nuestro objetivo en este programa es, esperamos, no únicamente convertir al pueblo mexicano a nuestra doctrina...

El PRESIDENTE (interrumpiendo). Usted dice “convertirlos”. ¿Qué quiere decir "convertirlos"?

Dr. INMAN. Me refiero llevarlos a la Iglesia.

El senador Fall estaba en lo cierto, se había fundado una estación experimental en Chihuahua capital y había planes para establecer otra más en las cercanías del llamado latifundio Terrazas, propiedad del exgobernador y cacique porfirista de la región, el general Luis Terrazas. Recuérdese también que las estaciones experimentales agrícolas tuvieron un papel fundamental en el desarrollo del sector primario estadounidense. Durante el último tercio del siglo xIX se abrieron sociedades agrícolas y estaciones experimentales en Carolina del Sur, Connecticut, Carolina del Norte, Cornell, New Jersey, Ohio y California. 
El PRESIDENTE. ¿Quiere decir cambiarlos de una religión a otra?

Dr. INMAN. Sí, señor.

El PRESIDENTE. ¿Qué religión tienen actualmente, aquellos a los que ha estado convirtiendo?

Dr. INMAN. Hay muchos que no practican ninguna religión; pero la gente allá es católica.

El PRESIDENTE. ¿La gran mayoría de la gente es católica?

Dr. INMAN. Sí, señor. Estamos basando el movimiento, como podrá ver, sobre el plan de servicio de nuestro programa y aunque, por supuesto, tenemos nuestras convicciones religiosas e intentamos ser coherentes con éstas, estamos en México con el simple propósito de cambiar las creencias teológicas.

El PRESIDENTE. ¿Haciendo proselitismo, quiere decir?

Dr. INMAN. Sí; estamos poniendo todo el empeño para sustentar el programa con base en el servicio, después vendrá un centro comunitario o una iglesia interinstitucional en cada capital importante de la república, una casa editorial de la Unión, un periódico y una librería de la Unión, ${ }^{10}$ en la Ciudad de México, además hemos establecido recientemente una campaña para popularizar el conocimiento médico. Esperamos conseguir la participación de algunos de los médicos mexicanos y otros de este país haciendo uso de los aparatos que presentan imágenes en movimiento, diapositivas, literatura y todo lo similar que llegue a diferentes sectores, fábricas o al interior de los distintos lugares a través de una campaña de higiene, tan necesaria en aquella ciudad.

El PRESIDENTE. ¿Ustedes van a los distritos rurales con su trabajo, o confinan sus instituciones, tanto religiosas como educativas, a las ciudades?

Dr. INMAN. No; también vamos a los distritos rurales. El propósito es definir la división territorial y cada una de las responsabilidades de los misioneros para evitar la superposición o duplicación del esfuerzo. A pesar de que éste pueda parecer un pequeño programa para solucionar un problema mayúsculo, nosotros creemos que si el programa - que por supuesto requiere la inversión de varios millones de dólares - se lleva a cabo, en muy pocos años tendrá un efecto inmenso sobre el problema mexicano.

Senador BRANDEGEE. Usted habló de escuelas y contar con un programa que tienda a solucionar el problema de la tierra. ¿Cuál es el problema de la tierra?

Dr. INMAN. Pienso que el problema de la tierra es principalmente la división de las enormes haciendas que han sido poseídas por pocas personas,ofreciendo tierra a la gente común y dándoles algún espacio de tierra para que la trabajen y, por lo tanto, alentarlos a ocuparse...

Senador BRANDEGEE (interrumpiendo). ¿Cómo es que sus escuelas de agricultura orientan una solución al problema de la tierra?

Dr. INMAN. Bueno, en este sentido, Senador, pienso que la gran dificultad de México no es el problema de la tierra, sino el problema de saber cómo cultivar la tierra. Si usted prefiere, enseñar a la gente a cultivar la tierra e inculcarles el 
espíritu de trabajo así como el conocimiento de cómo sacar los mejores resultados del terreno.

Senador BRANDEGEE. Supongo que toda la gente de México está totalmente preparada para labrar la tierra ¿Cómo se les puede educar? ¿Cómo contribuiría su proyecto educativo a solucionar el problema de la tierra, el dividir las grandes propiedades y distribuirlas entre la gente más pobre que no tiene tierra actualmente?

Dr. INMAN. Por supuesto que no serviría únicamente esa medida, pero cuando la gente sepa cómo cultivar la tierra, tendrán mayor capacidad de encargarse de la misma.

Senador BRANDEGEE. Pero en mi pregunta he asumido que son capaces de encargarse de la tierra, que ya han recibido educación para eso y ustedes terminarían de educarlos para la división de grandes haciendas, sea por confiscación o compra como parte de la política gubernamental.

Dr. INMAN (interrumpiendo). Sí.

Senador BRANDEGEE. Ningún aumento de educación en esa línea, enseñar cómo cultivar y cosechar, ayudaría al gobierno a resolver ese problema...

Dr. INMAN (interrumpiendo). Salvo que el gobierno apreciara que debe trabajar también con la gente y no únicamente dar a un hombre una porción de tierra que no sabe cómo cultivar...

Senador BRANDEGEE (interrumpiendo). ¿Pero no cree usted que la gente que ha vivido allá toda su vida sabe cómo cultivar su propia tierra?

Dr. INMAN. La gran mayoría de ellos todavía aran con una horquilla, como lo hacían hace siglos.

Senador BRANDEGEE. Sí; pero saben que hay otros instrumentos y otros tipos de arado.

Dr. INMAN. En muchos sectores nunca han visto otro tipo de arado.

El PRESIDENTE. ¿A qué distritos se refiere ahora?

Dr. INMAN. Bueno, en las montañas de Zacatecas por ejemplo.

El PRESIDENTE. ¿Qué cantidad de tierra cultivable hay en todo el distrito de Zacatecas, Doctor?

Dr. INMAN. Me parece que bastante, por la forma en que cultivan las laderas de las montañas. Cultivan la tierra allí porque no puede ser labrada donde en otros lados.

El PRESIDENTE. ¿Está testificando basado en su propio conocimiento o en algo que ha escuchado o ha leído?

Dr. INMAN. Estoy testificando basado en conocimientos generales.

El PRESIDENTE. ¿Conocimientos generales relativos al estado de Zacatecas? ¿Está usted testificando basado en su propio conocimiento?

Dr. INMAN. Esa es mi impresión general de Zacatecas.

El PRESIDENTE. Bueno, yo viví en Zacatecas hace 35 años, y quiero saber qué es lo que usted conoce al respecto ¿Alguna vez se ha alejado de la ruta del tren de Zacatecas?

Dr. INMAN. Debo admitir que no sé nada al respecto, si le resulta de ayuda. Senador BRANDEGEE. ¿Cuál es la religión que siguen esos "Discípulos" a los que usted se refiere?

Dr. INMAN. La Iglesia Cristiana y los Discípulos de Cristo. 
Senador BRANDEGEE. ¿Ciencia Cristiana $?^{11}$

Dr. INMAN. No, señor.

Senador BRANDEGEE. De acuerdo, en este programa que usted ha bosquejado y expuesto en el mapa ¿Hay alguna autoridad principal de todas estas denominaciones, que tenga el propósito de dirigir la empresa y recaudar los fondos para la erección de los edificios, pagar los gastos de los maestros y guiar la empresa después de que sea establecida?

Dr. INMAN. La responsabilidad recae en las distintas juntas misioneras y en el comité de cooperación. Ellos únicamente conciben todas las formas para llevarlo a cabo.

Senador BRANDEGEE. ¿Quién poseería los títulos de todas las propiedades que usted ha mencionado?

Dr. INMAN. Bueno, cuando la junta misional sea la que realiza el trabajo en el campo, ellos serían los propietarios, pero cuando sea una unión, estará en manos de un consejo formado por miembros designados de las múltiples instituciones.

Senador BRANDEGEE. Creo que usted no me entiende del todo. ¿Hay una organización central que tenga la autoridad de llevar a cabo estos proyectos, después de que las diferentes denominaciones hayan acordado acerca de qué clase y en qué medida comparten la responsabilidad? ¿En qué medida será su participación? o en otras palabras ¿El título de las propiedades estará en manos de miembros designados por las corporaciones de las distintas denominaciones? Dr. INMAN. Sí, señor. Por supuesto que cuando una denominación particular aporte el dinero, la propiedad se considerará suya y estará en manos de esa junta, como sucede actualmente.

Senador BRANDEGEE. ¿Qué medidas se han tomado para garantizar la unidad de acción, que sistema de cooperación, y cómo se asegura que se opere uniformemente...?

Dr. INMAN (interrumpiendo). Se han efectuado reuniones, la primera se llevó a cabo en la Ciudad de México en el mes de febrero, y otra en Cincinnati hace cinco años en la que las juntas designaron representantes.

Senador BRANDEGEE. ¿Trae usted ahora un proyecto por escrito para que podamos tener una idea informada de los resultados?

Dr. INMAN. Sí, señor; aquí lo tengo

Senador BRANDEGEE. ¿Tiene usted un borrador?

Dr. INMAN. Tengo un folleto que metí en este sobre [señalando].

Senador BRANDEGEE. Puede el Comité archivarlo, si usted tiene uno extra.

Dr. INMAN. Sí, señor; aquí está [entregando el mismo, al presidente].

Senador BRANDEGEE. No quiero decir que quedará registrado en el récord, ¿Sabe? Pero nos gustaría revisarlo.

Christian Science. Asociación religiosa fundada y organizada en 1879 por Mary Baker Eddy. Baker, nacida en Boston, Mass., proclamaba ser un instrumento por medio del cual Dios expresaba los misterios de la revelación bíblica. Además de estar convencidos en el poder milagroso de la mente para curar el cuerpo, los miembros de esta iglesia afirman

ser los restauradores de la iglesia original surgida del Nuevo Testamento. Baker abrió una Universidad de metafísica en 1881 y gracias a ésta se hizo millonaria. Murió en 1910. 
El PRESIDENTE. ¿Todos estos documentos que trae en el sobre los entregará al Comité?

Dr. INMAN. Sí, señor.

Senador BRANDEGEE. Entonces no lo separe de los otros.

Dr. INMAN. ¿Dijo usted que no debo dejar el mapa?

El PRESIDENTE. Sí; puede dejarlo, pero no lo podemos "reproducir en el récord". ${ }^{12}$

Dr. INMAN. Comprendo.

El PRESIDENTE. Doctor, supongo que usted tiene un asociado que está más familiarizado con el problema agrario.

Dr. INMAN. Actualmente estamos solicitando a un experto agrícola que vaya [a México], un hombre que ha sido director de una escuela de agricultura en Brasil por muchos años. Uno de los misioneros en Brasil le ha telegrafiado para que compre varios cientos o varios miles de cabezas de ganado, que él ha estado dirigiendo en gran medida para el mantenimiento de sus fuerzas vivas.

El PRESIDENTE. ¿En sus investigaciones sobre América Latina ha enfocado su atención en el hecho de cuándo se originó la agricultura en este hemisferio? ¿No sería ese un tema de interés para usted?

Dr. INMAN. Es un suceso muy antiguo.

El PRESIDENTE. ¿Tiene usted idea de en qué momento?

Dr. INMAN. Las autoridades que he leído sobre el tema difieren tanto, que no declararé sobre eso.

El PRESIDENTE. ¿Sabe usted algo relacionado con la época de la civilización Inca en Perú, acerca de cuánto tiempo se supone que antecedió a la llegada de los españoles?

Dr. INMAN. Algunas autoridades afirman que el propio Inca es más bien moderno, pero no puedo recordar en este momento cuál fue la civilización que precedió la suya. Posiblemente mucho más de 1,000 o tal vez 2,000 años antes de la llegada de los españoles.

Senador BRANDEGEE. ¿Doctor, cuántos escritos de autoridades ha leído usted sobre el tema?

Dr. INMAN. Leí un artículo que sostiene decididamente los orígenes tempranos de la agricultura en Norte Americana.

El PRESIDENTE. ¿Quién es el autor de ese artículo?

Dr. INMAN. Sir Edward Markham, probablemente la mayor autoridad en esa cuestión. Vivió por 40 años en Perú y dedicó toda su vida a la investigación. Por supuesto, también al Profesor Hiram Bingham, de la Universidad de Yale, que ha realizado algunas investigaciones en aquel lugar.

El PRESIDENTE. ¿Sabe usted de qué fecha data la historia de la agricultura según los arqueólogos o científicos, cualquiera de los periodos de la historia de la agricultura en este hemisferio, y específicamente en el norte del continente?

12 No hay referencia de que las comparecencias fuesen grabadas en cintas magnetofónicas, por lo que la frase "guárdarlas en el récord" sugiere integrarlas al reporte o a las pruebas de descargo del compareciente. 
Dr. INMAN. No sé de qué antigüedad data según las autoridades, no siglos, pero yo diría 1,000 años, en todo caso.

E1 PRESIDENTE. Encontrará un boletín del Departamento Smithsoniano ${ }^{13}$ que rastrea este suceso en el continente hasta 100 años antes de Cristo por periodos precisos.

Dr. INMAN. Pueden encontrarse muchos escritos de autoridades que difieren de eso. Por supuesto, hay escuelas que siempre gustan de colocar a esta civilización en periodos tan antiguos, y lo hacen. Ellos piensan que tienen buenas fuentes históricas.

El PRESIDENTE. A lo que intentaba dirigirlo era a sus conocimientos sobre agricultura. Usted habla de enseñarles sobre agricultura a estas personas en México.

Dr. INMAN. No sé nada sobre agricultura.

El PRESIDENTE. Entiéndame, no estoy en contra, ni pretendo desaprobar ninguno de los planes que tiene proyectado para enseñar agricultura moderna, pero usted parece seguir la teoría de que esas personas en México no saben nada de agricultura.

Dr. INMAN. Ellos no conocen nada, por ejemplo, sobre el uso moderno de nuevos instrumentos. Una gran mayoría de ellos no lo sabe.

El PRESIDENTE. Ahora está haciendo una declaración general, Doctor. ¿Ha estado usted en las zonas agrícolas alejadas de las ciudades de Chihuahua o el estado de Sonora?

Dr. INMAN. No, señor; no he estado ahí.

El PRESIDENTE. En su lugar, yo no volvería a sostener esa declaración sin haber estado allá.

Dr. INMAN. Dije una gran mayoría de ellos, Senador.

El PRESIDENTE. Ya sé que dijo una gran mayoría. Le estoy preguntando acerca de dos estados al norte de la república con los que yo estoy familiarizado y en los que he estado durante muchos años.

Dr. INMAN. ¿En esos dos estados la mayor parte de la gente está familiarizada con los modernos instrumentos agrícolas y los análisis de suelo?

El PRESIDENTE. Yo fui al corazón de la cordillera de la Sierra Madre en 1889, por donde nunca había pasado un vehículo de dos ruedas, y vi carruajes ligeros de dos ruedas jalado por caballos que araban la tierra en los alrededores de Temósachic, Nuerichic $[$ sic $],{ }^{14}$ San Buena Ventura del Valle, Las Cruces y otros lugares que se extendían desde Casas Grandes hasta bajar al corazón de las Sierras Madres y de vuelta al estado de Chihuahua. No había allí granjas mexicanas por pequeñas que fuesen que no tuvieran una moderna máquina estadounidense para arar e instrumentos agrícolas con los que trabajar.

Ahora, déjeme señalarle que esas mismas personas seguían usando exactamente los mismos métodos que dicen los arqueólogos y otros que se usaban

13 Se refiere al Instituto Smithsoniano fundado en 1846, con sede en Washington D.C., que cuenta con bibliotecas, museos y archivos para la investigación histórica, el arte, la cultura, la ciencia y la tecnología, entre otras disciplinas.

14 En la prensa estadounidense aparece también como Neurichic, poblado en donde se escondían las tropas de Pancho Villa. 
para trabajar la tierra hace 2,000 años. En otras palabras, ellos trabajan sus tierras de manera diferente. Puedo decirle que después de que indague, encontrará, si envía a su experto agrícola allá, que aplican actualmente los métodos de cultivo en seco (dry farming) con mayor éxito que lo que hemos desarrollado en casi cualquier parte de los Estados Unidos.

Dr. INMAN. ¿Usted afirmaría que eso es igual para la mayoría de los mexicanos que trabajan en fincas o sí?

El PRESIDENTE. Esa es una buena pregunta. Usted utiliza esos términos genéricos, "la mayoría de las personas" ¿Sabe usted algo acerca del Río Fuerte ${ }^{15}$ en la costa occidental?

Dr. INMAN. Algo sé.

El PRESIDENTE. ¿Nunca ha estado allí?

Dr. INMAN. No, señor.

El PRESIDENTE. Entonces no tiene un conocimiento personal al respecto; no conoce los métodos de cultivo que ellos usan.

Dr. INMAN. No, señor.

Senador BRANDEGEE. Usted no tiene los medios y no podría tener los medios para distinguir la mayoría de la minoría.

Dr. INMAN. Por supuesto que en la investigación, antes de que establezcamos esas escuelas, los tendremos.

Senador BRANDEGEE. No estoy hablando de lo que pueda descubrir; pero usted dice que la mayoría de la gente no sabe nada de los modernos métodos de cultivo. Usted no tiene contacto con la mayor parte de la gente en las lejanas regiones mexicanas.

Dr. INMAN. ¿Usted cree que podría testificar acerca de lo que la mayor parte de la gente en Estados Unidos está haciendo en lo relativo a su forma de cultivar?

Senador BRANDEGEE. No, no lo creo. No es mi intención tener contacto cercano con ellos ni me atrevería a decir lo que la mayoría de las personas piensa sobre cualquier cosa. En todas las elecciones presidenciales cada uno de los partidos piensa que la mayoría de los votantes estarán con ellos. Siempre se equivocan. Constantemente he pensado que un hombre con esas ideas no ha vivido lo suficiente como para saber qué conforma una mayoría. Opino que está hablando disparates cuando hace ese tipo de afirmaciones.

Dr. INMAN. Muy bien, señor.

El PRESIDENTE. Doctor, el propósito del interrogatorio del Senador Brandegee no es únicamente criticarlo, sino también llamar la atención al hecho de que cuando se hacen declaraciones tan generales, como las que usted ha hecho y se hacen públicas, generalmente ayudan a crear impresiones bastante erróneas en Estados Unidos, aunque no de manera intencional, por supuesto. Usted, francamente, ha hecho una declaración general respecto a lo que la mayoría de la gente puede hacer y lo que usted está haciendo por ellos. Al igual que su declaración con referencia a la agricultura.

15 El río Fuerte es un extenso afluente que cruza los estados de Chihuahua y Sinaloa, en sus riveras se encuentran algunos de los centros más antiguos de la región, inclusive de la etapa prehispánica. 
Dr. INMAN. Señor Presidente, tome por ejemplo el libro Forjando Patria, el autor de éste es sin duda una autoridad. ${ }^{16}$

El PRESIDENTE. Doctor, tomaré ese libro y otros registros y le demostraré que todo frijol cultivado en Estados Unidos de América, actualmente, desde las regiones árticas hasta el sur, tuvo su origen en lo que llamamos América Central, y lo mismo con el maíz, el tabaco y las papas.

Dr. INMAN. Por supuesto, tengo pleno conocimiento de eso.

El PRESIDENTE. ¡Oh! ¿Realmente lo tiene?

Dr. INMAN. Sí.

El PRESIDENTE. ¿Conoce usted al Dr. George W. Scott?

Dr. INMAN. Sí, señor.

El PRESIDENTE. ¿Sabe usted en qué trabajo se ocupa actualmente el Dr. Scott?

Dr. INMAN. Él es uno de los secretarios o asistente del secretario de la Junta Presbiteriana.

El PRESIDENTE. ¿Sabe usted qué trabajo específico relacionado con México, si es que hace alguno, efectúa hoy por hoy?

Dr. INMAN. No, señor.

El PRESIDENTE. ¿Sabe usted quiénes están asociados con él en este trabajo?

Dr. INMAN. Sé que el Dr. Scott está ahora en el oriente. No tengo conocimiento que tenga alguna relación con el trabajo que se realiza en México.

El PRESIDENTE. ¿Sabe usted del trabajo llevado a cabo por algún grupo de estadounidenses, algún trabajo de investigación con referencia a México, las condiciones agrícolas, las condiciones educativas y todas las condiciones prevalecientes en México? ¿Incluido el desarrollo de energía hidráulica y trabajos de ese tipo, o de naturaleza filantrópica que se estén realizando en México?

Dr. INMAN. No, señor.

El PRESIDENTE. ¿Sabe algo, por ejemplo, de la relación del señor Newell con labores y reportes semejantes sobre México?

Dr. INMAN. No, señor.

El PRESIDENTE. Usted menciona en su libro que un capitalista se hizo de $\$ 100,000$ por ayudar a un grupo de profesores universitarios a investigar asuntos concernientes a la educación. ¿Sabe usted algo acerca de este trabajo?

Dr. INMAN. ¿Esa investigación que fue hecha por la Fundación del señor Doheny?

El PRESIDENTE. El señor Edward Doheny, quien está aquí presente.

Dr. INMAN. No conozco al señor Doheny.

El PRESIDENTE. Es el caballero que está sentado junto al señor Walker. ¿Conoce usted al señor Walker [señalando]?

El doctor Inman se refiere al libro de Manuel Gamio, Forjando Patria (Pro Nacionalismo) publicado por la Librería de Porrúa Hermanos en 1916. La portada del libro presenta al autor como Presidente de la Delegación Mexicana en el II Congreso Científico Panamericano y en el XIX Congreso de Americanistas, efectuado en Washington en 1915-1916. Inspector General de Monumentos Arqueológicos de la República, Director de la Escuela Internacional de Arqueología y Etnología Americanas, así como Profesor de Historia Patria en la Academia Nacional de Bellas Artes. 
Dr. INMAN. Sí, señor. Hice una referencia a la fundación del señor Doheny en la última parte de mi libro.

El PRESIDENTE. ¿Sabe usted algo acerca del trabajo de dicha fundación? ¿O de los lineamientos que se siguen para realizarlo?

Dr. INMAN. Salvo lo que he platicado con el Profesor Cox. Él me ha contado sobre sus avances acerca del trabajo educativo, fue bajo esos mismos lineamientos sugeridos por el profesor Cox que nosotros realizamos nuestro trabajo.

El PRESIDENTE. ¿Entonces hay un laico que sugirió ciertas ideas que usted consideró eran buenas y las cuáles sigue en su trabajo?

Dr. INMAN. No pienso que ese haya sido el origen, de ninguna manera.

El PRESIDENTE. Usted dijo que [las ideas] le fueron sugeridas por el Dr. Cox y que lo conoce por el trabajo educativo que la Fundación Doheny estaba realizando.

Dr. INMAN. Sí, señor.

El PRESIDENTE. ¿El señor Doheny es el director de la Mexican Petroleum Co. y tiene grandes intereses petroleros en México, es correcto?

Dr. INMAN. Sí, señor.

El PRESIDENTE. ¿Usted sabe eso?

Dr. INMAN. Sí, señor.

El PRESIDENTE. ¿El profesor Cox fue financiado por la Fundación Doheny?

Dr. INMAN. Sí, señor.

El PRESIDENTE. ¿Usted adoptó algunas sugerencias y ha trabajado acorde a ellas?

Dr. INMAN. Yo no diría que hemos adoptado esas sugerencias en particular.

El PRESIDENTE. ¿Usted no las ha rechazado, o sí?

Dr. INMAN. Coinciden - me parece - con las diversas investigaciones que he hecho [en México] como ya lo he indicado, relativas al modo práctico del trabajo en campo.

El PRESIDENTE. Por cierto, hablando de los problemas de la tierra en México, ¿Conoce usted la gran meseta elevada, que promedia de 6,000 a 8,000 pies de elevación y, hablando de manera general, se extiende desde El Paso, Texas, hacia el sur a través del estado de Zacatecas? ¿Y que es recorrida en toda su longitud por la Mexican Central Road?

Dr. INMAN. He pasado por allí.

El PRESIDENTE. ¿Sabe usted algo sobre la agricultura a lo largo de esa ruta?

Dr. INMAN. No personalmente; no, señor.

El PRESIDENTE. ¿Son como 800 o 1,000 millas de distancia?

Dr. INMAN. Eso supongo.

El PRESIDENTE. ¿Con muchos cultivos a la vista?

Dr. INMAN. No muchos.

El PRESIDENTE. ¿Qué piensa usted de fragmentar esas tierras en pequeñas parcelas y entregárselas a los egresados de su escuela de agricultura?

Dr. INMAN. No pienso que funcionaría muy bien, a menos que ellos pudieran realizar cultivos en seco o algo por el estilo.

El PRESIDENTE. ¿Doctor, que hacía usted aproximadamente hacia 1915, en el momento que el señor Carranza fue reconocido por este gobierno? ¿En dónde se encontraba usted? 
Dr. INMAN. ¿En 1915?

El PRESIDENTE. Sí.

Dr. INMAN. Acababa de salir de México y establecí mi residencia en Nueva York. Me hallaba organizando el Congreso de Panamá.

El PRESIDENTE. ¿Estuvo usted a favor del reconocimiento de Carranza por este gobierno?

Dr. INMAN. Sí.

El PRESIDENTE. ¿Conoce usted otros ministros o misioneros que también estuvieran a favor de su reconocimiento en ese momento?

Dr. INMAN. No recuerdo individuos específicos. Pienso que cierto número de ellos estaban a favor.

El PRESIDENTE. ¿Puede usted mencionar algunos que hayan tomado parte activamente en ello?

DR. INMAN. ¿En conseguir el reconocimiento?

El PRESIDENTE. Sí.

Dr. INMAN. No.

El PRESIDENTE. ¿Y en ayudarle [a Carranza], tanto antes como después de su reconocimiento? ¿Recuerda a alguno?

Dr. INMAN. No, señor.

El PRESIDENTE. ¿Cuándo dejó usted su misión en Saltillo o Monterrey, o dondequiera que estuviese su centro de operaciones?

Dr. INMAN. Dejé México en enero de 1914 para hacer un viaje a Sudamérica. Después regresé en el otoño y estuve allí pocas semanas, posteriormente me mudé a Nueva York.

El PRESIDENTE. ¿Conoce usted al Dr. David Starr Jordan?

Dr. INMAN. No, señor. Tengo noticias de él, pero no lo conozco personalmente. El PRESIDENTE. ¿Sabe usted algo de sus actividades a lo largo de la frontera mexicana?

Dr. INMAN. No, señor.

El PRESIDENTE. ¿O en México?

Dr. INMAN. No, señor.

El PRESIDENTE. ¿Al Reverendo Henry Allen Tupper?

Dr. INMAN. No, señor.

El PRESIDENTE. ¿No sabe absolutamente nada sobre él?

Dr. INMAN. Sé de él, sólo como una figura pública, pero nunca lo he conocido o he tenido relación alguna con él.

El PRESIDENTE. ¿Tenía conocimiento de sus actividades en México?

Dr. INMAN. Leí algunos de sus artículos, uno en el Outlook, según recuerdo.

El PRESIDENTE. ¿Él favorecía el reconocimiento de Carranza y el gobierno de Carranza, cierto?

Dr. INMAN. El artículo que recuerdo no discutía sobre el reconocimiento de Carranza.

El PRESIDENTE. ¿Usted no prestó atención a los que el Dr. Jordan o el reverendo Rice, en El Paso, u otros ministros hicieron con referencia a Carranza y su reconocimiento? ¿Los que favorecían al gobierno de Carranza, tanto antes como después de su reconocimiento? 
Dr. INMAN. No más que cualquier otro asunto de interés. Sobre lo que apunta, no tuve conocimiento sobre el particular.

El PRESIDENTE. ¿Usted estaba interesado en México en ese momento, o no?

Dr. INMAN. Sí, señor; quiero decir, como un asunto de interés general, pero no tuve conexión de otro tipo.

El PRESIDENTE. ¿Sabe usted de misioneros o ministros que hayan recibido dinero de Carranza, antes de su reconocimiento o desde entonces?

Dr. INMAN. No, señor; no lo sé.

El PRESIDENTE. ¿Absolutamente de ninguno?

Dr. INMAN. Absolutamente ninguno.

El PRESIDENTE. ¿Por trabajo de propaganda o de algún otro tipo?

Dr. INMAN. De ningún modo.

El PRESIDENTE. ¿Sabe usted de alguno?

Dr. INMAN. No lo sé.

El PRESIDENTE. ¿Sabe en dónde se encuentra el señor Tupper ahora?

Dr. INMAN. No, señor; no lo sé.

El PRESIDENTE. ¿Sabe algo sobre algún fondo de publicidad para trabajos de propaganda que actualmente son realizados, aparte del que usted ha llevado a cabo a favor de Carranza en este país?

Dr. INMAN. No lo sé.

El PRESIDENTE. Doctor, usted está familiarizado con México y habla español. Observo que entre la propaganda difundida por su Comité o por la Liga de Naciones Libres se encuentran bocetos del "Oil, Paint, and Drug Reporter, Nueva York, 11 de agosto de 1919"; entre esos un artículo titulado "La postura oficial de México en la controversia petrolera", escrito para el Oil, Paint, and Drug Reporter, por orden del presidente Carranza, cuyo autor es Joaquín Santaella, jefe de la comisión técnica petrolera en México, que señala "respondiendo a la petición hecha al presidente mexicano para que manifestara oficialmente su posición frente a la disputa petrolera existente”. ¿Ha leído usted ese artículo?

Dr. INMAN. Le he echado un ojo.

El PRESIDENTE. Con el conocimiento que tiene de México desde 1905 hasta la actualidad ¿Piensa usted que [el artículo] represente correctamente la situación mexicana en cuanto al petróleo, las leyes y todo ese asunto?

DR. INMAN. Señor presidente, no lo he leído cuidadosamente. Realmente no lo sé.

El PRESIDENTE. ¿Permite usted que artículos de ese tipo sean difundidas por algún Comité, con el que esté relacionado, sin haberlos leído y sin saber de qué tratan?

Dr. INMAN. Sí, señor. Una gran cantidad de éstos.

El PRESIDENTE. ¿También difundirlos sin importar la forma en que hayan llegado?

Dr. INMAN. Sí, aunque no he tenido conocimiento sobre eso...

El PRESIDENTE. ¿No tiene usted ningún abogado que revise todo tipo de cuestiones legales?

Dr. INMAN. No, señor. 
El PRESIDENTE. ¿Así que usted puede difundir un escrito de este tipo, proveniente de Carranza, como parte de su trabajo propagandístico, sin investigar si expone la ley o la situación imperante?

Dr. INMAN. Acepto que esa sería responsabilidad de la Liga de Asociación de Naciones Libres.

El PRESIDENTE. ¿Si ellos se equivocan, si el señor Santaella no expone de manera correcta la ley mexicana, la responsabilidad de difundir información incorrecta de ese tipo es una responsabilidad de la Liga de Naciones Libres?

Dr. INMAN. Sí, señor.

El PRESIDENTE. ¿No tienen ningún abogado a quien se le presente ese tipo de noticias?

Dr. INMAN. No lo sé, me parece que no, si bien hay uno o dos abogados en el Comité.

El PRESIDENTE. ¿No piensa que es una gran responsabilidad para cualquier organización el difundir datos o material propagandístico de este carácter, cuando hay una cuestión inquietante, como usted dice, ante el pueblo mexicano concerniente a los intereses petroleros de México? A menos que pueda avalar que [la propaganda] es correcta.

Dr. INMAN. Pienso que debe saber algo sobre el tema.

El PRESIDENTE. ¿Es una gran responsabilidad, no lo cree?

Dr. INMAN. Sí, es una gran responsabilidad.

El PRESIDENTE. ¿Tienen ustedes algún comité que transmita esta propaganda, los artículos de De Bekker o cualquier otro que haya sido difundido?

Dr. INMAN. Nadie más que la gente que trabaja en las oficinas, eso es todo lo que sé.

El PRESIDENTE. ¿Alguien a quien se entregue la información para que revise su corrección? ¿Cualquier partido puede ver difundida la información por su comité, o la Liga de Naciones Libres, sin que pase por los directores responsables?

Dr. INMAN. Hasta donde yo sé, no hay revisión alguna que siga esa línea.

El PRESIDENTE. ¿Sabe usted quién le está pagando al señor De Bekker por este material propagandístico?

Dr. INMAN. Entiendo que actualmente es empleado de la Liga de Asociación de Naciones Libres.

El PRESIDENTE. ¿Sugiere que un artículo de esta naturaleza - sobre el tema del que acabo de llamar su atención - fue hecho por encargo? Un texto que afirma y expone la antigua ley española y la ley mexicana desde, me parece, una fecha tan antigua, 1793, hasta nuestros días y referido al petróleo ¿sabe si fue pagado?

Dr. INMAN. Naturalmente, supongo que el periódico paga por cualquier artículo que obtiene.

El PRESIDENTE. ¿También lo difundido por su comité o de otra forma? La entrevista que el señor Santaella envió ¿es parte de su propaganda?

Dr. INMAN. Recuerdo haberla visto.

El PRESIDENTE. ¿Quién paga por eso?

Dr. INMAN. Supongo que la Liga de Naciones Libres pagó por la publicación del artículo.

El PRESIDENTE. ¿Quién paga por la publicación de las pruebas? 
Dr. INMAN. La Liga de Asociación de Naciones Libres.

El PRESIDENTE. ¿Y las publican sin relacionarla con algún partido? ¿Quién es el responsable de comprobar la veracidad o falsedad de las declaraciones que contienen?

Dr. INMAN. El presidente del comité ejecutivo, obviamente, está en la oficina todo el tiempo.

El PRESIDENTE. ¿Quiere decir el señor McDonald?

Dr. INMAN. Sí, señor.

El PRESIDENTE. ¿Entonces, si la información no es correcta la responsabilidad de difundirla sería de él, cierto?

Dr. INMAN. Pienso que la responsabilidad de publicar los artículos recae oficialmente en la Liga de Asociación de Naciones Libres.

El PRESIDENTE. Archivaré este documento, no para imprimirlo en el registro, todavía. ¿Dr. Inman, sale usted esta tarde?

Dr. INMAN. Eso espero señor presidente.

El PRESIDENTE. No hay razón alguna para detenerlo por el momento, pero si debe de partir esta tarde me gustaría saberlo, en caso de que algo surja y sepa dónde encontrarlo.

(Después de consultar con el Consejo del comité)

He sido informado por el Consejo que ha estado cotejando su libro, que hay dos o tres preguntas que nos gustaría hacerle, en relación a algunas declaraciones en su libro. Si usted se presenta a las tres de la tarde abordaremos ese asunto.

Son las dos de la tarde, el subcomité tomará un receso hasta las tres horas.

\section{SESIÓN VESPERTINA.}

Después de haber tomado un receso, el subcomité se volvió a reunir a las tres de la tarde, preside el Senador Fall.

\section{TESTIMONIO DEL DR. SAMUEL GUY INMAN (Continúa)}

El PRESIDENTE. El secretario del Comité me informa que hay una rectificación que le gustaría hacer.

Dr. INMAN. Una corrección referida a la declaración que realicé esta mañana, en lugar de la Asociación para la Protección de los Derechos Estadounidenses en México, a la que me referí cuando abordamos la propaganda carrancista, fue la Asociación de Productores de Petróleo la que hizo tal declaración.

El PRESIDENTE. ¿Y quiénes son?

Dr. INMAN. No lo sé. Sencillamente fue esa firma la que apareció en el Times. Senador BRANDEGEE. ¿Cuál es la diferencia entre petróleo crudo y refinado? Dr. INMAN. La discrepancia radica meramente en los nombres de las dos organizaciones a las que me he referido.

Senador BRANDEGEE. ¿Cuáles eran los nombres de las dos organizaciones?

Dr. INMAN. Una fue la Asociación para la Protección de los Derechos Estadounidenses y la otra fue la Asociación de Productores de Petróleo.

El PRESIDENTE. ¿El señor Edward Doheny está en ambas asociaciones, cierto? 
Dr. INMAN. No conozco ambas organizaciones. Supongo que sí, aunque nunca he visto el registro de dichas corporaciones.

El PRESIDENTE. ¿Esa es la única rectificación que quiere hacer, verdad?

Dr. INMAN. Sí, señor.

El PRESIDENTE. [Doctor Inman] En la página 14 de su libro, veo que menciona: "Si alguien revisara el número de rumores publicados cada semana en la prensa estadounidense — referido a los terribles acontecimientos en México-, en poco tiempo se percataría que son probadamente falsos y estaría dispuesto a preguntarse seriamente qué intereses están dirigiendo a nuestra prensa."

¿Cuál es su conclusión? ¿Quiénes están dirigiendo nuestra prensa? ¿Qué quiso decir con "estaría dispuesto a preguntarse seriamente qué intereses están dirigiendo a nuestra prensa?

Dr. INMAN. La pregunta es si existen intereses en contra del gobierno mexicano. El PRESIDENTE. ¿Qué intereses son esos? ¿Tiene usted conocimiento de algunos intereses específicos que estén en contra del actual gobierno mexicano? Dr. INMAN. No. Yo simplemente digo que uno cuestionaría de manera natural desde su propia percepción...

El PRESIDENTE. ¿No sabe que influencias o intereses están en contra del actual gobierno mexicano? ¿Tenía algo específico en mente?

Dr. INMAN. No.

Senador BRANDEGEE. ¿A qué grado llegan, lo que usted refiere como "informes terribles” sobre los sucesos en México, los que dice prueban ser falsos? ¿Hasta qué punto son probadamente falsos posteriormente?

Dr. INMAN. Pienso que en una buena parte.

Senador BRANDEGEE. ¿No son corregidos generalmente?

Dr. INMAN. De forma general, no; pero si lo hacen, aparecen en letras pequeñas en alguna parte del periódico.

Senador BRANDEGEE. ¿Piensa usted, como afirmación general, que la prensa estadounidense está siendo influenciada para presentarle a sus compatriotas una imagen falsa de la situación mexicana?

Dr. INMAN. Bueno, yo no digo eso.

Senador BRANDEGEE. ¿Quiero decir, piensa usted que es así?

Dr. INMAN. Me inclino a pensar que sí.

E1 PRESIDENTE. Doctor, cualquier tipo de noticia que haya surgido del interior de México y haya salido fuera del país ¿cómo llegaría? ¿Cómo se comunica al exterior? ¿Si se envía de manera telegrafiada quién posee las líneas telegráficas? Dr. INMAN. El gobierno.

El PRESIDENTE. ¿El gobierno de Carranza?

Dr. INMAN. Sí.

El PRESIDENTE. ¿Hay censura, o no del gobierno de Carranza sobre cualquier noticia que salga por las líneas telegráficas?

Dr. INMAN. Pienso que sí.

El PRESIDENTE. ¿Y también sobre los telegramas provenientes de México?

Dr. INMAN. Pienso que sí, pero no estoy completamente seguro de eso, es sólo mi impresión.

El PRESIDENTE. Usted sabe que todas las líneas telegráficas son propiedad, o se sostiene que son propiedad, del gobierno. 
Dr. INMAN. Sí.

El PRESIDENTE. Por lo que todo material que llegue de México a través de esas líneas, llega a través de la Mexican National Lines. Ahora bien ¿De dónde provienen esas noticias de las que habla? ¿De México o de la frontera?

Dr. INMAN. Bueno, hablo de noticias en general; algunas llegan de la frontera y otras llegan desde el interior de México; algunas vienen de Washington y otras de Nueva York.

El PRESIDENTE. Tiene referencia de eso.

Dr. INMAN. Me refiero a una lectura general de los periódicos.

El PRESIDENTE. A las noticias que hacen referencia a México y generalmente son incorrectas $i$ Se refiere a los acontecimientos al interior de México?

Dr. INMAN. Hay una gran cantidad de noticias incorrectas y si uno simplemente se tomara la molestia de revisarlas, las encontraría.

El PRESIDENTE. ¿Qué método de revisión sigue usted? Ahora suponga un caso, que de su ciudad de Monterey, donde usted solía estar, llegue un telegrama como al que usted hace referencia aquí, en la página 14 de su libro: "Quien revisara el número de rumores publicados cada semana por la prensa estadounidense con relación a los terribles acontecimientos en México...", sospeche que esos acontecimientos terribles que llegan de Monterey son un rumor. Si la nota llega por telégrafo, llega por medio de las líneas telegráficas de Carranza ¿Cierto?

Dr. INMAN. Sí.

El PRESIDENTE. ¿En el momento lo revisaría y probaría que es incorrecto?

Dr. INMAN. Tengo en mente un ejemplo, la prensa de Estados Unidos informó que el gobernador Osuna había sido capturado por bandidos.

El PRESIDENTE. ¿De dónde provino eso?

Dr. INMAN. No sé de dónde salió.

El PRESIDENTE. ¿De dónde pretendía haberse tomado u originado?

Dr. INMAN. Digo que no recuerdo; pero esa fue la nota escrita en los periódicos. Por supuesto, yo estaba bastante preocupado, hasta que varias semanas después escuché de unos amigos que estaban en México que tal cosa no había sucedido.

Senador BRANDEGEE. Bueno, pero usted nunca realizó una prueba sistematizada para comprobar qué era falso y qué era cierto ¿O lo hizo?

Dr. INMAN. No.

El PRESIDENTE. Cualquier periodista estadounidense en la República Mexicana que se encuentre en una guarnición carrancista, un gobierno carrancista o bajo la administración territorial de un funcionario carrancista y envíe noticias de ese tipo, es sujeto de deportación bajo la ley mexicana ¿No es así?

Dr. INMAN. Si hace cualquier cosa considerada como objetable, me parece que el presidente tiene la autoridad para deportarlo.

El PRESIDENTE. Bien ¿Considera usted responsables a los estadounidenses por los falsos rumores originados y provenientes de México? ¿Considera usted que son responsables de tener algún interés especial en Estados Unidos?

Dr. INMAN. No.

El PRESIDENTE. ¿Sabe usted que los corresponsales de la Prensa Asociada han sido arrestados y deportados de la Ciudad de México, sin juicio alguno?

Dr. INMAN. He escuchado mencionar algo.

El PRESIDENTE. ¿Eso se hace bajo la autoridad de la Constitución, o no? 
Dr. INMAN. Entiendo que bajo la autoridad del viejo artículo 33. No conozco el nuevo artículo. Los estadounidenses lo llaman el 33.

El PRESIDENTE. ¿Y sabe usted que hay un tratado entre los Estados Unidos y México que prohíbe tal acción?

Dr. INMAN. No, señor.

El PRESIDENTE. ¿Qué comunicaciones de prensa ha visto llegar de la frontera y que usted haya revisado o haya probado ser incorrectos?

DR. INMAN. En este momento no tengo alguno en mente.

El PRESIDENTE. ¿Ha revisado algunos que hayan resultado ser incorrectos?

Dr. INMAN. La fabricación en la frontera, la fabricación de noticias, es una discusión considerable y generalizada que se menciona en una gran cantidad de artículos.

El PRESIDENTE. ¿En dónde?

Dr. INMAN. Con mucha frecuencia, prácticamente en todas las revistas.

El PRESIDENTE. ¿Sólo en declaraciones tan generales como las que está usted haciendo ahora?

Dr. INMAN. Hay declaraciones bastante específicas a lo largo de todo el año. El PRESIDENTE. Eso es a lo que trato de llegar.

Dr. INMAN. Sin duda debe usted recordar que se hace referencia al hecho, de manera general, que en la frontera hay muchas declaraciones inventadas, aunque no recuerdo ninguna de éstas.

El PRESIDENTE. Vamos a indagarlo y, si está en poder del comité, vamos a rastrear y demostrar si hay alguien que genere noticias, enviándolas desde la frontera o desde cualquier parte, con el propósito de excitar las mentes de los estadounidenses. Quisiera saber si la Associated Press está involucrada con este asunto ¿Usted sabe?

Dr. INMAN. No, no sé si lo está.

El PRESIDENTE. ¿Entonces absuelve a la Associated Press de tal cargo?

Dr. INMAN. No tengo evidencia de que la Associated Press haya hecho algo así. Yo nunca hice una acusación en contra de ella.

El PRESIDENTE. ¿Entonces contra quién está haciendo las acusaciones?

Dr. INMAN. Señor Presidente, simplemente estoy declarando que al leer los escritos surgen este tipo de observaciones. Yo no levanté acusaciones. Se pueden leer asuntos en los escritos que simplemente están allí, sin poner una mano sobre ellos y decir "Sé que esto fue hecho por éste, aquél u otro hombre u organización". El PRESIDENTE. Esta es una declaración bastante general de su parte.

En la página 18 observo que dice "sin duda las declaraciones fueron hechas de forma imprudente por aquellos que pensaban que exagerar un poco podría dar mayor énfasis a las malas condiciones. Pero en México, donde de hecho la gente vive en condiciones completamente diferentes, aquellas no parecían más que mentiras condenables que buscaban un propósito. Cuando algún reportero quiere una 'primicia', algún congresista quiere complacer a sus electores, por decirlo de algún modo algo, o algún orador necesita después del banquete despertar a los comensales, México sigue siendo un tópico en el que todos están interesados y del cual pocos conocen. Lo que ofrece un estupendo campo de acción”. ¿Qué congresista tenía usted en mente?

Dr. INMAN. Ninguno en particular. 
El PRESIDENTE. ¿Entonces ésta es solamente una afirmación general?

Dr. INMAN. Sí; pero es...

El PRESIDENTE (interrumpiendo). ¿Ha sido testigo o le han hecho saber de algunos ejemplos en que congresistas, $u$ oradores después de la cena, hayan dado discursos incendiarios o arengas que no estén fundamentados en hechos, referentes a asuntos en México?

Dr. INMAN. Por supuesto, allí me refiero al informe que se había hecho sobre México, que decía que Carranza no controlaba más que el 5 por ciento del país.

El PRESIDENTE. ¿A eso es a lo que hace referencia aquí?

Dr. INMAN. Acerca de que ese informe agitaba a la gente allá; sí.

El PRESIDENTE. ¿Cuándo fue eso?

Dr. INMAN. Eso se reportó en los periódicos cuando yo estaba allá, en febrero.

El PRESIDENTE. ¿A través del discurso de qué congresista?

Dr. INMAN. No fue el discurso de un congresista, sino una cena que se llevó a cabo, me parece que hago referencia a ella justo antes del artículo que usted citó. El PRESIDENTE. ¿Entonces se refiere usted al discurso del vicepresidente de la Guaranty Trust Company?

Dr. INMAN. Sí, tal como fue informado en México.

El PRESIDENTE. ¿Bueno, pero The World Tomorrow ${ }^{17}$ no se publica en México, o sí?

Dr. INMAN. No.

El PRESIDENTE. Usted cita el discurso de The World Tomorrow de marzo de 1919.

Dr. INMAN. También fue reportado en periódicos mexicanos con grandes encabezados en color rojo que cruzaban la parte superior de la página y que causaron un gran revuelo allá.

El PRESIDENTE. ¿El discurso fue citado incorrectamente en México o citado de la manera en que usted lo cita a partir de The World Tomorrow?

Dr. INMAN. En México fue un resumen siguiendo las mismas líneas.

Senador BRANDEGEE. Refiriéndonos al vicepresidente de la Guaranty Trust Co., que es la misma compañía de cuyos proyectos hizo usted referencia ayer, y de quien mencionó al público que era aconsejable para ellos hacer inversiones en México. ¿Es correcto?

Dr. INMAN. La misma; sí.

El PRESIDENTE. Usted cita este discurso superficialmente de la siguiente manera: "Gracias a una cuidadosa censura, muy pocas noticias reales han salido oficialmente de México en los últimos dos años, pero por fuentes privadas hemos sabido que las condiciones se han vuelto intolerables. Compañías de negocios estadounidenses con grandes beneficios en ese territorio han sido obligadas a organizarse recientemente, con el propósito de llamar la atención pública sobre la situación y, de ser posible, asegurar algunas medidas de protección por parte de nuestro gobierno.

17 Es probable que se refiera a The World Tomorrow: A Journal Looking toward a Christian World, una publicación de carácter político entre 1918 y 1934 que en sus primeros tres años tuvo como primer editor a Norman Thomas (1884-1968), ministro presbiteriano y seis veces candidato presidencial por el Partido Socialista de Estados Unidos (SPA) 
El hecho que inquieta a todos aquellos interesados sinceramente en el bienestar del pueblo mexicano, y de quienes quisieran ver a los mexicanos progresar, es que México no tiene la semilla en su interior para lograr lo que de manera evidente debe alcanzarse antes de poder disfrutar de un gobierno libre e iluminado. Debe buscar la ayuda del exterior para elevarse sobre las condiciones caóticas que existen en la actualidad. La nueva Constitución mexicana, adoptada recientemente, es bolchevique en su teoría y estipulaciones. Decreta que el mantenimiento de una propiedad es una función social, además dispone la confiscación categórica de los derechos de propiedad, como es entendida por los estadounidenses y todos los gobiernos civilizados".

¿Ese fue propiamente el discurso que se dio como noticia en México, o se le hizo alguna modificación antes de ser publicado?

Dr. INMAN. Por supuesto, la mayor parte de él fue publicado, me parece que una extensión mayor fue presentada en The World Tomorrow. Yo extraje esa parte de la cita que me pareció especialmente ofensiva, porque no quería transmitir esa postura.

El PRESIDENTE. ¿Es ese es el discurso que tenía en mente, al afirmar que cuando algún reportero quiere una primicia o un orador quiere despertar a los comensales después de una cena, México, siendo un tópico en el que todos están interesados y del cual pocos conocen algo, brinda un estupendo campo?

Dr. INMAN. Ese no es el discurso completo.

El PRESIDENTE. ¿Es ese el que usted tenía en mente?

Dr. INMAN. Sí.

El PRESIDENTE. ¿Usted llamó mi atención sobre el hecho de haber citado el texto?

Dr. INMAN. Sí. Yo simplemente hice referencia al escrito como uno de los temas que agitaba a los mexicanos desde su territorio.

El PRESIDENTE. Cierto, y una de las cosas que usted considera como falsa.

Dr. INMAN. Sí, señor.

El PRESIDENTE. Observo que en su libro, en la página 28, usted coloca la confiscación de propiedades de extranjeros en México, o el tema de la confiscación, aparentemente, en el mismo plano de la enmienda de prohibición ${ }^{18}$ que se aprobó por el Congreso de Estados Unidos. ¿Recuerda usted ese párrafo? Dr. INMAN. Lo recuerdo; pero mi intención no era colocarlo en ese plano, sino simplemente hacer notar que muchas personas podrían hacerlo.

El PRESIDENTE. Usted dice en la página 28: "Acabamos de confiscar propiedades de millones de extranjeros al aprobar la enmienda de prohibición, sin embargo, nadie pensaría que ésta dio a algún gobierno extranjero el derecho de intervenir en nuestros asuntos". Usted estaba comparando la enmienda [18] con el artículo 27 de la Constitución Mexicana. ¿Piensa que ésta es una comparación justa? 
Dr. INMAN. Mi idea en ese punto era resaltar el hecho de que existe reconocimiento del poder del Estado para expropiar propiedades, que por ejemplo se está discutiendo en Gran Bretaña actualmente.

El PRESIDENTE. Esta es su idea, ¿le parece una comparación justa?

Dr. INMAN. Simplemente quería exponerla como una reflexión.

El PRESIDENTE. ¿Cómo una comparación justa?

Dr. INMAN. Como una reflexión para el lector.

El PRESIDENTE. Bueno, ¿cuál era su idea personal sobre el particular?

Dr. INMAN. Que el lector hiciera sus propias comparaciones.

El PRESIDENTE. ¿Tiene usted algún interés personal sobre el asunto o escribió después alguna reflexión?

Dr. INMAN. No que recuerde. Simplemente es uno de los temas que se tiene muy presente en la actualidad, relacionados con la nacionalización de propiedades en todas partes del mundo.

El PRESIDENTE. Me percato, que al referirse a la Doctrina Monroe, en la página 33, usted menciona que "Chile, Colombia, Nicaragua y otros países e incontables individuos latinoamericanos piensan $-\mathrm{y}$ no debemos olvidar que sostienen este argumento con citas de nuestras propias autoridades - que no quiere decir “América para los americanos", sino "América para los estadounidenses". ¿Qué autoridades de nuestro país son citadas en ese tema?

Dr. INMAN. Tome por ejemplo el libro del profesor Powers, America Among the Nations, ${ }^{19}$ escrito durante la guerra; y que aborda ese tema como argumento, prácticamente en todo el libro.

El PRESIDENTE. ¿Escrito durante la guerra?

Dr. INMAN. Escrito durante la guerra.

El PRESIDENTE. ¿Alguna vez ha oído usted que lo citen en Latinoamérica?

Dr. INMAN. Sí, señor.

El PRESIDENTE. ¿Dónde y por quién?

Dr. INMAN. Es citado en una serie de artículos que se están publicando actualmente en The North American ${ }^{20}$ y que llega a Latinoamérica. Tengo un libro escrito en portugués, prácticamente en su totalidad se dedica a tales citas.

El PRESIDENTE. ¿Cuándo fue publicado ese libro?

DR. INMAN. El libro fue publicado hace 10 años.

El PRESIDENTE. Pensé que había dicho que durante la guerra.

Dr. INMAN. No; dije que el libro del Dr. Powers se publicó durante la guerra.

El PRESIDENTE. Eso es lo que estoy preguntando. ¿Aproximadamente cuándo salió? ¿Cuál fue la fecha, lo recuerda?

Dr. INMAN. No la recuerdo. Fue a finales de 1917.

19 Se refiere al libro de Harry Huntington Powers (1859-1936) publicado en Nueva York en 1917, un texto de filosofía política que expone las razones para que una nación extienda su poderío, incluida la rapiña, y "coseche donde no ha sembrado o colecte donde no le corresponde", pero al mismo tiempo critica el comportamiento y declaraciones de los políticos de la época.

20 Una de las publicaciones periódicas que conserva la Biblioteca del Congreso de Estados Unidos, editada en Filadelfia desde 1839. 
El PRESIDENTE. ¿Sobre qué fuentes se basa el señor Powers al hacer tales aseveraciones? ¿Intentó citar algún archivo del Estado o escritos del Departamento del Interior o documentos ejecutivos?

Dr.INMAN. No, me parece que no lo hace; pero, como digo, este otro libro, el libro brasileño, cita las palabras de nuestro Departamento de Estado y de muchos otros hombres prominentes del Congreso.

El PRESIDENTE. ¿Concuerda usted con este libro portugués o brasileño después de haber revisado las fuentes? ¿Que la Doctrina Monroe signifique declaradamente "América para los estadounidenses" o que, por mencionarla

cualquier autoridad competente del país, sea así? ¿Después de leer el libro está usted de acuerdo con el argumento?

Dr. INMAN. Más bien estoy en desacuerdo con él.

El PRESIDENTE. ¿Tomó algunas medidas para sacar del error a los latinoamericanos que piensan así, referente al verdadero significado de la Doctrina Monroe?

Dr. INMAN. Trato de hacerlo en todo momento que tengo la oportunidad; trato de demostrarles que ese no es el significado de la Doctrina Monroe.

El PRESIDENTE. Somos afortunados de tener alguien que lo haga. Leo en su libro: "Los mexicanos son gente explotada. El terrateniente y el cura han continuado su impía alianza desde los días de los Conquistadores hasta el presente, pasando de una a otras manos a fin de mantener a la gente en la ignorancia, la superstición y la deuda... de manera que la explotación de ambos, padre y amo, es segura y fácil. ¿Esta afirmación la hace de conformidad con el debate de las condiciones actuales de México, o las existentes en México durante los últimos 300 años?

Dr. INMAN. En efecto.

El PRESIDENTE. Me doy cuenta que usted también afirma que: "Capitalistas extranjeros, con sus inmensas concesiones, usualmente han estado dispuestos a unirse al sistema de explotación”. ¿Eso es verdad?

Dr. INMAN. Sí.

El PRESIDENTE. ¿Qué inmensa concesión conoce usted, dentro de su comprensión, y es mantenida por cualquier forastero, estadounidense o de otra nacionalidad, en México?

DR. INMAN. Concesiones... No puedo recordar en este preciso momento.

El PRESIDENTE. ¿Cómo puede ser que el usufructo de cualquier concesión, a menos que pueda usted recordarla, permita a alguien explotar a la gente de México? ¿En otras palabras, qué tipo de concesión tendría que ser esa?

Dr. INMAN. Creo que debería ser una concesión del gobierno.

El PRESIDENTE. ¿Qué tipo de concesión del gobierno?

Dr. INMAN. Eximiéndolos, por ejemplo, de impuestos y dándoles ciertos privilegios.

El PRESIDENTE. ¿Qué tipo de concesión tiene usted en mente?

Dr. INMAN. Tome cualquier cantidad de ésas de las referencias hechas en el libro del señor Turner sobre México. 
El PRESIDENTE. ¿Se refiere usted a [John] Kenneth Turner? ${ }^{21}$

Dr. INMAN. En efecto.

El PRESIDENTE. México Bárbaro.

Dr. INMAN. Sí, señor.

El PRESIDENTE. ¿Escrito en colaboración, me parece, con Gutiérrez de Lara? ${ }^{22}$

Dr. INMAN. Sí.

El PRESIDENTE. ¿Usted lo considera una autoridad?

DR. INMAN. Considero que una gran parte de las afirmaciones descritas ahí son indiscutibles; sí, señor.

El PRESIDENTE. ¿Ha tomado usted algunas medidas para corroborar si dichas afirmaciones son ciertas?

Dr. INMAN. Ninguna medida para corroborarlas.

El PRESIDENTE. ¿Solamente las considera como verdaderas porque las leyó?

Dr. INMAN. En efecto.

El PRESIDENTE. ¿El señor Turner hace referencias a concesiones [a extranjeros] en ese libro?

DR. INMAN. Sí, señor.

El PRESIDENTE. ¿Lo hace?

Dr. INMAN. Me parece que sí.

El PRESIDENTE. ¿Y se refería a concesiones a extranjeros en ese momento?

Dr. INMAN. En efecto, se refería a concesiones a extranjeros.

Senador BRANDEGEE. ¿Da algún ejemplo específico de concesión a extranjeros que colaboraran en la explotación a los mexicanos?

Dr. INMAN. Ha pasado algún tiempo desde que leí el libro.

El PRESIDENTE. Yo he leído el libro y conozco algo de las condiciones a las que hace referencia. Se refería él a las condiciones agrícolas en las regiones tropicales de México.

Dr. INMAN. En parte; sí, señor.

John Kenneth Turner (1897-1948), periodista que a los 17 años publicó su primer diario, Stockton Saturday Night, en el que denunció actos de corrupción de políticos y empresarios de inicios del siglo xx. Estudió en la Universidad de California y se casó con Ethel Duffy Turner —quien organizaba y acogía a los magonistas en Los Ángeles y traducía y editaba los artículos y notas de Regeneración - . En esas lides, John, trabajó como reportero de Los Angeles Express conoció a los miembros del Partido Liberal Mexicano, entre ellos a los hermanos Flores Magón y a Lázaro Gutiérrez de Lara. Impactado con México y la desigualdad de sus pobladores, se dedicó a criticar a la vieja clase política, simpatizó con Venustiano Carranza, escribió sobre Pancho Villa y se opuso a una posible invasión de Estados Unidos sobre el vecino país del sur en pleno conflicto mundial. Su último libro, Desafio a Karl Marx, se publicó en 1941.

22 El Senador Fall, se refiere a Lázaro Gutiérrez de Lara Salazar (1870-1918), líder obrero de la huelga de Cananea, Sonora, de 1906, socialista, abogado, escritor y periodista quien conoció a John Kenneth Turner en Estados Unidos y lo acompañó como traductor durante sus recorridos por el sur de México. De ese periplo surgieron las descripciones de México Bárbaro publicadas en The American Magazine, durante los meses previos a la Revolución maderista, y luego compilados como libro, donde recrea la explotación de la mano de obra indígena en las haciendas porfiristas de Yucatán y puso en evidencia las contradicciones del capitalismo mexicano de la época. 
El PRESIDENTE. ¿Pero no es ese el tema de toda su obra - las regiones tropicales de México- en las plantaciones? ¿Sobre eso escribía Kenneth Turner, o no? ¿La deportación de los pobladores de la región del Yaqui, del Río Fuerte y sus alrededores hacia Campeche, Yucatán u otras regiones, y las condiciones laborales en esas plantaciones?

Dr. INMAN. En efecto.

El PRESIDENTE. A eso es a lo que él [Turnes] se refería. ¿Sabe usted qué significado tiene una concesión en México?

Dr. INMAN. Hay varios tipos. Una concesión es un privilegio especial otorgado por el gobierno a alguien.

El PRESIDENTE. ¿Conoce usted a alguien, quien quiera que sea - mexicano o extranjero, estadounidense o de cualquier otra nacionalidad- que posea en México, hoy en día, un pedazo de tierra por concesión del gobierno de ese país? Dr. INMAN. No sé de algún individuo en particular; no puedo mencionar a alguno en este momento.

El PRESIDENTE. De su conocimiento sobre México ¿Alguna vez escuchó de algún individuo o corporación que posea tierra del gobierno mexicano por concesión hasta nuestros días?

Dr. INMAN. El gobierno de México ha otorgado tierras, por ejemplo, a ciertos individuos, después de que las tribus indígenas fueran desposeídas, y esos individuos se hicieron cargo de la propiedad de la tierra.

El PRESIDENTE. ¿Otorgó las tierras?

Dr. INMAN. Bueno, hizo posible que ese individuo obtuviera la tierra.

El PRESIDENTE. Bien Doctor, ahora usted está expresando exactamente lo que buena cantidad de personas, que no saben más del tema que usted, han expresado con anterioridad. La venta de tierras mexicanas se anuncia [de manera pública] y se ofrece para todo aquel que quiera comprar, desde una hectárea, que es la unidad básica, 2.47 acres, hasta cualquier cantidad de hectáreas que podamos o queramos comprar. ¿Son estas concesiones de las que usted habla, de las que los indígenas fueron despojaos? ¿Sabe si tenían títulos y eran reconocidos por la oficina gubernamental y que los ingenieros del gobierno eran los encargados de medirlas? ¿Sabe que las quejas de los indígenas surgieron debido a que con base en esas mediciones lo que ellos consideraban previamente como sus propiedades pudieron verse reducidas? ¿Tiene conocimiento de qué esto es cierto o lo desconoce?

Dr. INMAN. Bueno, no estoy seguro de los detalles que señala, pero ¿acaso no es cierto, por ejemplo en el estado de Morelos, que los indígenas poseían previamente estas tierras?

El PRESIDENTE. ¿No es cierto que, en el estado de Dakota del Sur, los estados de Dakota del Norte, Colorado, Nuevo México, el estado de Nueva York, el estado de Maryland y otros estados de la Unión, los indios reclamaron previamente la tierra?

Dr. INMAN. Es verdad, pero también es cierto que actualmente unos pocos hombres son dueños de estados enteros, como ocurre en Morelos.

El PRESIDENTE. ¿Quién se ha encargado de arreglar los problemas en Morelos? Dr. INMAN. No sé si se están arreglados en este momento. 
El PRESIDENTE. ¿Quién se ha dedicado personalmente a ello en los últimos nueve años? ¿El señor Carranza?

Dr. INMAN. Zapata tiene el control de eso.

El PRESIDENTE. ¿Zapata?

Dr. INMAN. Sí, señor.

El PRESIDENTE. ¿Y su labor se ha basado en la teoría de que él arreglaría los títulos de propiedad en Morelos?

Dr. INMAN. Teóricamente en eso se basaba.

El PRESIDENTE. ¿Él era partidario de Carranza, cierto?

Dr. INMAN. No creo que lo fuera. Sin duda no lo siguió hacia el final.

El PRESIDENTE. Sí, señor. ¿Alguna vez supo o tuvo alguna razón para investigar los títulos de las compañías petroleras, por los cuales eran dueñas de tierras en México?

Dr. INMAN. Entiendo que las compañías petroleras compraron directamente sus tierras.

El PRESIDENTE. ¿Entonces usted piensa que las compañías petroleras tienen concesiones u operan bajo concesiones?

Dr. INMAN. No, señor.

El PRESIDENTE. Absuelve usted a las compañías petroleras de eso ¿verdad?

Dr. INMAN. Sí, señor.

El PRESIDENTE. ¿Qué estadounidenses piensa usted que poseen tierras bajo concesiones? ¿Piensa usted que alguna de las compañías mineras posee tierras por concesión?

Dr. INMAN. Asumo que las compañías mineras, de acuerdo con la ley, tienen concesiones del gobierno para explotar las minas.

El PRESIDENTE. Esto evidencia el hecho de que usted no ha investigado sobre el tema. Las minas no operan bajo concesión alguna. Las mismas autoridades que usted cita en su libro y la afirmación que hace en él contradicen el argumento. Las minas son adquiridas no por concesión, sino que son adquiridas por denuncia, como lo denomina el gobierno mexicano, a través de la oficina minera más cercana a la localidad.

Dr. INMAN. Eso es justo lo que yo quería decir.

El PRESIDENTE. ¿A eso es a lo que usted llama una concesión? ¿Las minas son concesiones?

Dr. INMAN. Supongo que, técnicamente, no.

El PRESIDENTE. Es una patente expedida por el gobierno mexicano, firmada por el presidente de la república, legítimamente igual a como nosotros obtenemos patentes por nuestra propiedad, salvo que ellos tienen una condición subsecuente. En el caso de incumplimiento en el pago de impuestos por tres meses consecutivos, se pierde automáticamente el derecho de propiedad, se devuelve y [la mina] queda sujeta para ser denunciada por alguien más. No hay ningún privilegio especial en eso, si usted o alguien más tiene el derecho de hacer la denuncia por cualquier instancia minera ¿me equivoco?

Dr. INMAN. No, señor; salvo que es un arreglo con el gobierno.

El PRESIDENTE. ¿Entonces las compañías mineras no operan bajo concesiones? Dr. INMAN. No, señor; no cuando operan en sus propias tierras. 
El PRESIDENTE. Ellos pueden ser dueños de la mina y pueden adquirir la mina, o pueden tomar una mina por otorgamiento. Usted puede tener el título, que date de 200 años atrás, y recibirlo del rey de España o algún virrey de la Nueva España, y puede localizar una mina de minerales metalíferos, así que debo adquirir la tierra con usted.

Dr. INMAN. Entiendo.

El PRESIDENTE. Si usted y yo no podemos llegar a un acuerdo, acudo a la Corte, bajo la ley mexicana, a levantar una demanda de inconformidad. La única diferencia entre esa ley y la nuestra es que un hombre tiene el derecho al denuncio minero y al hacerlo adquiere el derecho eminente de dominio, lo que no se otorga comúnmente en este país. ¿Tenía conocimiento de esto?

Dr. INMAN. Sí, señor.

El PRESIDENTE. Entonces, ¿las compañías mineras operan bajo concesiones?, ¿actualmente qué estadounidenses están trabajando bajo concesiones?

Dr. INMAN. Por ejemplo, hay fábricas en México exentas del pago de ciertos impuestos, por algunos años, para alentarlas a permanecer y tengo entendido que se le otorgan concesiones. Si estoy equivocado sobre el particular, estaré contento de saberlo.

El PRESIDENTE. La ley mexicana de tierras está publicada en un libro por separado. Usted puede conseguirlo. Si no lo logra yo puedo proveerle una copia. Por otro lado, ¿qué son estas concesiones manufactureras?, ¿a qué equivalen? , ¿de qué forma permiten a alguien explotar al trabajador pobre?

Dr. INMAN. A cualquier fabricante, por supuesto, al darle la oportunidad de desarrollar su negocio, si no quiere pagar a sus empleados y puede mantenerlos empleados lo hará por cualquier medio, negociando con el cabecilla político o con cualquier otro.

El PRESIDENTE. Pero esa no es la cuestión. ¿Llama usted a eso una concesión?, ¿cómo esa acción le permite explotar a los hombres con salarios bajo?, ¿en dónde se permite emplearlos con salarios bajos y mantenerlos empleados, en lugar de que se vayan a otro lado?, ¿alguna vez ha oído usted de una concesión de ese tipo? Dr. INMAN. Salvo por el hecho de que él trabaja en contubernio con las autoridades y eso le permite vigilar que esos trabajadores se queden allí y trabajen para él.

El PRESIDENTE. Eso no aplica para una concesión. Eso podría aplicarse para un individuo o alguien más. Si usted fuera a ese lugar y se involucrara en cualquier tipo de negocio, ya fuera bajo lo que usted llama una concesión o no — por cierto, erróneamente repetido e invariablemente nombrado como concesión-e inicia cualquier tipo de negocio, ya sea agrícola, una caballeriza, un taller o cualquier otra cosa, y emplea hombres ¿Cómo puede presentarse con el funcionario público y sobornarlo? ¿De qué manera esta acción le permite controlar el trabajo?

Dr. INMAN. Le permite controlar el trabajo simplemente por estar bien relacionado con él.

El PRESIDENTE. ¿Cómo dice? ¿Usted pretende decir que todavía hay peonaje en México o esclavitud?

Dr. INMAN. No en este momento, excepto, diría yo, en casos inauditos; pero sin duda la esclavitud existió ampliamente durante la administración de [Porfirio] Díaz. 
El PRESIDENTE. ¿Sabe usted qué era el sistema de peonaje?

Dr. INMAN. He escuchado bastante sobre lo que era.

El PRESIDENTE. ¿Qué era?

Dr. INMAN. Por ejemplo, si un hombre tenía cierto número de peones en su hacienda, podía retener a esos peones por medio del endeudamiento. Si esos peones que le debían se fueran a otro estado, se le otorgaba autoridad al hacendado para ir, capturarlos y llevarlos de vuelta.

El PRESIDENTE. ¿Y dice usted que eso tiene algo que ver con las concesiones? Dr. INMAN. Quiero decir que sería muy natural, para un hombre que tuviera una concesión del gobierno, estar en alianza con los numerosos funcionarios del gobierno en la región.

El PRESIDENTE. ¿Empleó usted algún mozo mientras vivía en México?

Dr. INMAN. Generalmente, no.

El PRESIDENTE. ¿Empleó usted algún cocinero?

Dr. INMAN. En contadas ocasiones.

El PRESIDENTE. ¿Usted mismo se cocinaba, iba por su propio caballo y se servía por completo?

Dr. INMAN. Sí, señor.

El PRESIDENTE. ¿Conoció usted a alguien o tenía relación con alguien que fuera lo suficientemente afortunado como para contratar un mozo y un cocinero? Dr. INMAN. Sí, señor.

El PRESIDENTE. ¿Tenían que estar bien relacionados con las autoridades para poder quedarse con su cocinero y mozo?

Dr. INMAN. No, señor; yo estoy refiriéndome a las regiones periféricas del país. El PRESIDENTE. Sé a qué se está refiriendo. Se está refiriendo al viejo sistema de peonaje que fue suprimido hace años, no a una concesión. Fue abolido por la ley mexicana hace años. Nunca tuvo relación con las concesiones y todo lo demás que he señalado y encontrado aquí en su libro, sobre la explotación habitual de las personas. ¿Está al tanto que una concesión, como de la que usted ha estado hablando, es de hecho una simple franquicia para hacer negocios?

Dr. INMAN. Supongo que sí.

El PRESIDENTE. Si usted pone una red de tranvías en Washington o en cualquier otra ciudad de Estado Unidos, ¿tendría que contar con una franquicia de las autoridades?

Dr. INMAN. Sí, señor.

El PRESIDENTE. ¿Obtiene usted algún privilegio especial, aparte de tener simplemente una franquicia para operar?

Dr. INMAN. En realidad, hay mucha camaradería entre la gente que posee las franquicias y los funcionarios de esas ciudades.

El PRESIDENTE. Donde hay tratos corruptos, ¿eso es a lo que usted se refiere?

Dr. INMAN. Sí, señor.

El PRESIDENTE. En términos generales su afirmación podría aplicar a cualquier franquicia expedida en Estados Unidos. ¿Funciona igual a una franquicia o lo que usted llama una concesión expedida en México?

Dr. INMAN. Sí, señor, en donde quiera que existan ese tipo de asociaciones.

El PRESIDENTE. Sin embargo, nada hay en las franquicias que refieran el control del trabajo. 
Dr. INMAN. No, señor.

El PRESIDENTE. Muy bien. ¿Está usted consciente de que este gobierno ha otorgado concesiones ferrocarrileras a lo largo del continente en el pasado?

Dr. INMAN. Sí, señor.

El PRESIDENTE. ¿Para estimular al capital privado a construir y operar las vías férreas?

Dr. INMAN. Sí, señor.

El PRESIDENTE. ¿Está usted consciente del hecho de que las ciudades, municipalidades y pequeños poblados a lo largo del país, han ofrecido incentivos para que las fábricas se ubicaran allí?, ¿tiene conocimiento de eso?

Dr. INMAN. Sí, señor.

El PRESIDENTE. ¿Es esa una concesión, tal y como la pensaba para el caso de México?

Dr. INMAN. No; lo que tenía en mente era, retomando en conjunto el párrafo completo, que cuando las concesiones son expedidas por los funcionarios y las otorgan, se genera al mismo tiempo una alianza con esos empleados corruptos. Así es como funciona, no la parte legal de la concesión, sino como una parte de todo el arreglo institucional.

El PRESIDENTE. ¿Quiere decir como si por medio de sobornos y corrupción, usted pudiera ir mañana a la ciudad de Cleveland, Ohio, y conseguir una concesión de tranvía o de luz eléctrica o de gas, o algo por el estilo, a través de un arreglo perverso?

Dr. INMAN. Sí, señor.

El PRESIDENTE. ¿A eso es a lo que usted hacía referencia al hablar de una concesión en México?

Dr. INMAN. Sí, señor.

El PRESIDENTE. ¿Y eso es lo que usted quiere decir cuando habla en la página 45 de su libro de las inmensas concesiones extranjeras en México?

Dr. INMAN. Sí, señor.

El PRESIDENTE. Doctor, se estableció usted en Monterrey por primera vez en 1905.

Dr. INMAN. Sí, señor.

El PRESIDENTE. ¿Aproximadamente cuánta gente estaba empleada en las fundidoras o trabajos de ese tipo allá en ese momento?

Dr. INMAN. ¿Quiere decir en total?

El PRESIDENTE. Sí, señor.

Dr. INMAN. ¿Trabajadores y todo?

El PRESIDENTE. Sí, señor.

Dr. INMAN. Supongo que en las tres fundidoras se empleaban probablemente 5,000 personas.

El PRESIDENTE. ¿Sabe usted algo de la escala de salarios?, ¿cuánto se pagaba allí?

Dr. INMAN. Me parece que pagaban en ese entonces... no recuerdo lo que pagaban, probablemente alrededor de un peso. Quiero decir por el trabajo de peón.

El PRESIDENTE. ¿Y de un peso o un dólar mexicano en adelante?

Dr. INMAN. Sí, señor. 
El PRESIDENTE. ¿La sociedad anónima era dirigida por estadounidenses?

Dr. INMAN. Sí, señor, y las empresas estadounidenses de ese tipo en México pagan por lo general salarios más altos que las negociaciones mexicanas, más de lo que los trabajadores mexicanos están acostumbrados a recibir.

El PRESIDENTE. Entonces los establecimientos estadounidenses no han agraviado a la gente pobre de México.

Dr. INMAN. No, señor. Las grandes empresas, creo haber declarado, fueron de gran beneficio para la gente de México.

El PRESIDENTE. Me di cuenta de que lo hizo. Iba a llamar su atención sobre eso, como ejemplo de otra contradicción en su libro. El juez Kearful ha llamado mi atención sobre la página 10 de su libro, en donde usted dice "Millones de hombres dependen del capital estadounidense para su manutención”. ¿Cuál es la condición general de los trabajadores empleados por estadounidenses en México, habla de lo que tiene conocimiento?

Dr. INMAN. [Su condición] es mejor que en lugares donde pudieran emplearse con alguien más, justo como lo declaré con relación al asunto de Monterey.

El PRESIDENTE. ¿Cómo da razón de ese asunto? Usted está involucrado en trabajo social, elevación espiritual, educación, religión... debe de haber meditado sobre ese asunto.

Dr. INMAN. Me doy cuenta del asunto de dos maneras, como muchos de los administradores me lo han explicado. En primer lugar, porque los administradores están interesados en su gente, generalmente desde una perspectiva social, creen sobre todo que el cuidar de las personas y tenerlos satisfechos es un buen plan de negocios. Esto evita que se desplacen de un lugar a otro.

El PRESIDENTE. ¿Y de lo que usted ha observado, el sistema ha funcionado bien?

Dr. INMAN. Ha funcionado bien; sí, señor.

El PRESIDENTE. ¿Ha sido adoptado por los propios mexicanos?

Dr. INMAN. Bueno, no me importaría decir que no, pero en realidad no conozco ejemplos sobresalientes.

El PRESIDENTE. En cualquier caso, no ha sido antes de que los estadounidenses llegaran.

Dr. INMAN. Me parece que no.

El PRESIDENTE. Entonces, la entrada del empresario estadounidense al campo laboral mexicano ha funcionado para la elevación y beneficio del trabajador mexicano, ¿ha sido así?

Dr. INMAN. Aquellos que han sido empleados por los estadounidenses.

El PRESIDENTE. ¿Acaso no tiene el mismo efecto cuando hay gran demanda de trabajo con altos salarios en todo el país?

Dr. INMAN. Bueno, señor presidente, pienso es bastante difícil que el efecto llegue a todo el país. Por ejemplo, los lugares que están muy alejados de las vías férreas y tienen poco contacto con los centros, difícilmente son impactados por cualquier cambio, salvo lo que sucede allí, en su propia comunidad.

El PRESIDENTE. ¿Piensa usted que la mano de obra empleada en Monterrey, digamos lo que usted menciona de cinco mil, está conformada enteramente por residentes de Monterrey?

Dr. INMAN. Oh, no. Fueron traídos de distintas partes del país. 
E1 PRESIDENTE. ¿Fueron traídos de tan lejos como Zacatecas?

Dr. INMAN. Sí, señor; yo diría que sí.

El PRESIDENTE. Zacatecas se convirtió en una reserva de mano de obra minera para toda la República, después del cierre de las minas de la ciudad de Zacatecas ¿cierto?

Dr. INMAN. Sí, señor; San Luis Potosí, también y varios de los estados sureños. La fuerza de trabajo fue llevada por esas compañías estadounidenses hacia el norte.

El PRESIDENTE. Actualmente, ¿cuál es el salario promedio que los estadounidenses pagan al trabajador mexicano en Monterrey?

Dr. INMAN. Yo diría que alrededor de dos pesos para el trabajador manual o peón, y el peón a lo largo de todo el país percibe actualmente desde un dólar, un dólar veinticinco y un dólar y medio. Inclusive algunos municipios que solían pagar a sus policías 37 y medio centavos por día han incrementado su jornal.

El PRESIDENTE. Sí; también han aumentado los salarios de los soldados ¿cierto?

Dr. INMAN. Sí, señor; y los peones del interior del país. Me detuve[a charlar] con algunos hombres que llevaban materiales a las afueras de la ciudad, al lado de las vías, y pregunté cuánto recibían. Ellos percibían un dólar veinticinco centavos o cinco cuartillos $^{23}$ de maíz, me parece.

El PRESIDENTE. ¿Cuál es la preferencia de los trabajadores mexicanos, si es que tienen alguna, para emplearse con alguien?

Dr. INMAN. He escuchado frecuentemente, y explicado por ellos, que prefieren trabajar para los estadounidenses porque les ofrecen un trato justo. No tienen que pagar a los superintendentes, comisiones especiales para conservar su trabajo, como los que tienen que pagar, regularmente, a su propia gente.

El PRESIDENTE. ¿El trato, en general, es mejor?

Dr. INMAN. Yo diría que sí, señor presidente. He tenido una buena cantidad de amigos que fueron supervisores y conocidos que han ido a México como representantes de estas fábricas y tengo gran admiración por la labor que han realizado por los trabajadores mexicanos. No quiero, de ningún modo, causar la impresión que desapruebo a la gran mayoría de estadounidenses que han realizado negocios en México, o que suponga en algún sentido que su trabajo no haya sido realmente misional. Siempre he considerado que fue positivo.

El PRESIDENTE. De acuerdo. En otras palabras, usted piensa que, si los estadounidenses dejaran el trabajo en México, las condiciones serían peores de lo que son ahora.

Dr. INMAN. Sí,señor; así lo pienso.

El PRESIDENTE. Uno de los incentivos para que usted continúe con el trabajo con que se ha comprometido en México, es el hecho de que los estadounidenses estén explotando los recursos naturales del país y que ellos mismos estén apoyando al mexicano ¿Es correcto? plata. 
Dr. INMAN. No lo diría de ese modo, señor presidente.

El PRESIDENTE. ¿Entonces qué incentivos tendría usted si los estadounidenses abandonan su trabajo en México?

Dr. INMAN. Sencillamente sentimos que iremos a cualquier otro lado, África Central o alguna otra parte, para realizar nuestro trabajo.

El PRESIDENTE. Sin duda ¿tendrían ustedes, expectativas sobre su trabajo con el mismo placer y con la misma fe sincera en el resultado benéfico, inmediato o al final, si los estadounidenses fueran obligados a salir de México?

Dr. INMAN. No, señor; no las tendríamos.

El PRESIDENTE. Me refiero a los hombres de negocios de Estado Unidos.

Dr. INMAN. Sí, señor, consideraríamos eso una tremenda calamidad.

El PRESIDENTE. ¿Entonces piensa usted que ellos, igual que los demás, tienen el mismo derecho de ser escuchados en Estados Unidos?

Dr. INMAN. Ciertamente así lo pienso; sí, señor.

El PRESIDENTE. ¿Incluso cuando un congresista, que quiere asegurar la aclamación de sus representados, ofrece un discurso?

Dr. INMAN. Sí, señor.

El PRESIDENTE. Ahora bien, Doctor, me doy cuenta que hace una afirmación aquí en su libro, más bien es una comparación, referida a las condiciones imperantes bajo el gobierno de Díaz y bajo la administración actual. Usted expone aquí en las páginas 55 y 56 lo que cierto coronel haría con referencia a los dueños de ganado y similares. Usted habla del coronel aquí. ¿Recuerda usted ese párrafo?

Dr. INMAN. Sí, señor; recuerdo ese párrafo.

El PRESIDENTE. En una de las comunidades en las que viví, el caballero más prominente del pueblo, dueño de la mayor parte de los bienes raíces y quien controlaba cientos de miles de acres de tierra para cultivar, era llamado "coronel". Después de una residencia de varios años supe cómo se le había otorgado dicho título. Él había sido enviado a ese lugar como jefe político unos 20 años atrás. Organizó una banda de rufianes que cabalgaban por la región juntando rebaños de ovejas y ganado para él. Si el dueño de un pequeño hato ganadero los veía llevándoselo y preguntaba, “¿Quién les dijo que apartaran a ese ganado?” la respuesta era "El coronel". Si el dueño fuese lo suficientemente audaz como para ir a la ciudad y presentarse frente a las autoridades para exigir que se castigase a esa pandilla, ¿ante quién comparecería? Por supuesto, ante el coronel. Si insistía que se respetaran sus derechos, sería enviado a la cárcel y permanecería allí hasta reconocer la supremacía del coronel. Por lo tanto, el jefe político no contaba únicamente con su título de "coronel" sino también había amasado una inmensa fortuna. ¿Sabe usted de la existencia de condiciones de ese tipo en aquel país?

DR. INMAN. Sí, señor.

El PRESIDENTE. ¿Proveniente de su propia observación?

Dr. INMAN. En parte por observación propia.

El PRESIDENTE. Entonces usted concuerda con el texto: "Cuando los revolucionarios, siendo muchos de ellos los mismos hombres quienes habían sido robados por el Coronel, 10, 20 o 30 años antes, entraron en su hermoso hogar en la ciudad, después de que él lo había abandonado, tomaron algunos escritorios y camas para sus cuarteles, sus acciones fueron telegrafiadas a Estados 
Unidos para demostrar la barbarie de los revolucionarios". Sugiere que casos por el estilo provienen de su observación personal. ¿Es correcto, Doctor?

Dr. INMAN. Sí, señor; ese en particular sí.

El PRESIDENTE. ¿Requirieron algunos escritorios y camas para sus cuarteles?

Dr. INMAN. Sí, señor.

El PRESIDENTE. ¿Esto fue telegrafiado a lo largo de Estados Unidos?

Dr. INMAN. Sí, señor.

El PRESIDENTE. ¿Para mostrar el barbarismo de los revolucionarios?

Dr. INMAN. Sí, señor.

El PRESIDENTE. ¿Tiene usted ese ejemplo en mente?

Dr. INMAN. Sí, señor.

El PRESIDENTE. ¿Sabe usted algo acerca del saqueo de San Luis Potosí?

Dr. INMAN. Escuché esa historia la última vez que estuve allá.

El PRESIDENTE. ¿Tiene noticias del saqueo de Ciudad de México perpetrado por las fuerzas carrancistas cuando entraron en ella? ¿Alguna vez ha escuchado sobre el tema?

Dr. INMAN. Sí, señor.

El PRESIDENTE. ¿Es eso a lo que denominan "requerimiento"?

Dr. INMAN. No, señor. A lo que hice referencia es a lo que yo denomino "requerimiento".

El PRESIDENTE. ¿Qué casos tiene usted en mente? ¿La solicitación de escritorios?

Dr. INMAN. El caso que referí allí fue el de Piedras Negras.

El PRESIDENTE. ¿Cómo se realizó la solicitación?

Dr. INMAN. Ellos simplemente fueron, tomaron los muebles y los llevaron a sus cuarteles.

El PRESIDENTE. ¿Fuera de la casa del Coronel?

Dr. INMAN. Sí, señor.

El PRESIDENTE. ¿Y eso fue telegrafiado a Estados Unidos como un ejemplo de la barbarie de los mexicanos?

Dr. INMAN. Sí, señor.

El PRESIDENTE. ¿Usted vio los telegramas, los vio?

Dr. INMAN. Sí, señor.

El PRESIDENTE. ¿De dónde provenían?

Dr. INMAN. De Eagle Pass, Texas.

El PRESIDENTE. ¿Cómo es que las noticias llegaron a Eagle Pass, lo sabe?

Dr. INMAN. Es una corta distancia desde Eagle Pass y ahí había un gran número de corresponsales.

El PRESIDENTE. ¿Fue difundido por la AP o por un corresponsal especial?

Dr. INMAN. No recuerdo quién fue, quién lo difundió.

El PRESIDENTE. ¿Lo corrigió usted?

Dr. INMAN. ¿Que si lo corregí?

El PRESIDENTE. ¿Lo corrigió?

Dr. INMAN. Oh, no señor.

El PRESIDENTE. ¿Se tomó la molestia de ir al periódico correspondiente o a cualquiera de ellos y explicar que lo ocurrido había sido una simple solicitud de artículos y que en ningún sentido se trataba de un robo? 
Dr. INMAN. Por supuesto que no lo hice, señor presidente. De haberlo hecho no hubiera trabajado más en esos días, el tiempo se habría ido en tratar de corregir las declaraciones que habían sido difundidas por los periodistas.

El PRESIDENTE. Ahora, le pregunto sobre esta propaganda referente al petróleo y la supuesta ley mexicana. Llama mi atención el hecho al que usted hace referencia en su libro... me parece, que no tiene conocimiento de la ley, ni está personalmente familiarizado con la ley mexicana relativa a las minas.

Dr. INMAN. Ningún conocimiento, excepto el argumento general que las leyes mineras estipulan, que la propiedad permanecerá en manos del gobierno.

El PRESIDENTE. Ahora hace esta declaración de manera directa, quiero saber sobre qué información está fundada la aseveración: "Los españoles hicieron una distinción entre los derechos de la superficie y los derechos minerales. Esto reservaba para la Corona la propiedad exclusiva del subsuelo y, por lo tanto, la Corona mantuvo el título de todas las propiedades mineras. Cuando México se convirtió en una República, los derechos de la Corona pasaron al gobierno federal. Todas las leyes mineras mexicanas subsecuentes están basadas en esta tradición de propiedad gubernamental".

¿Sobre qué fundamentos afirma que bajo la ley española y mexicana los derechos del subsuelo fueron retenidos por la Corona y, posteriormente, por los gobiernos mexicanos?

Dr. INMAN. Eso es de un artículo escrito por mi colega, el Dr. Winton.

El PRESIDENTE. ¿Se encuentra aquí presente el Doctor?

Dr. INMAN. Sí, señor.

E1 PRESIDENTE. ¿Usted ha estudiado Derecho español o Derecho mexicano?

Dr. INMAN. No, señor.

El PRESIDENTE. ¿El Dr. Winston entiende esa ley mejor que usted?

Dr. INMAN. Sí, señor.

El PRESIDENTE. ¿Y conoce la diferencia, como usted la conoce, entre "metales" y "minerales", cierto?

Dr. INMAN. Sí, señor.

El PRESIDENTE. ¿Él entiende el español?

Dr. INMAN. Sí, señor.

El PRESIDENTE. Muy bien. Le preguntaré sobre eso al Doctor Winton cuando esté en el estrado. ¿Piensa usted que la ley mexicana del petróleo, bajo el artículo 27 , es decir lo que usted tiene referido como la ley petrolera mexicana, es distinta a la de otros países?

Dr. INMAN. No es distinta a la de otros países.

El PRESIDENTE. ¿De otros países en general?

Dr. INMAN. Bueno, eso es lo que afirman los mexicanos.

El PRESIDENTE. Y como el Dr. Winton, aparentemente, sabe más de eso que usted, lo interrogaremos más tarde. En la página 134 de este libro- quizá deba leer el párrafo entero- Usted dice:

"En febrero de 1913, Félix Díaz y Bernardo Reyes escaparon de la prisión de la Ciudad de México en donde habían estado encarcelados, por haber sido líderes de una rebelión en contra de Madero, y se colocaron a la cabeza de las fuerzas rebeldes representando al viejo grupo de Díaz. A Huerta se le confió el mando de las tropas maderistas. Para poder detener la lucha, que siguió 
durante 10 días, se llevó a cabo una reunión en la embajada estadounidense en la que estuvieron presentes el embajador estadounidense y Huerta, un traidor al presidente Madero, quien fue hecho prisionero y posteriormente asesinado. Por su participación en este asunto, Henry Lane Wilson fue destituido y Estados Unidos no designó hasta 1918 a nuestro siguiente embajador, el eficiente señor Fletcher, quien todavía sigue en su cargo".

Esto da la impresión de que el embajador de Estados Unidos, Henry Lane Wilson, formó parte de un asunto diabólico que tuvo como resultado el asesinato de Madero y Bernardo Reyes.

Dr. INMAN. Mi conocimiento sobre el tema es tal y como está escrito allí. El PRESIDENTE. ¿Quiere que se quede exactamente como está escrito allí? Dr. INMAN. Sí, señor.

El PRESIDENTE. ¿No titubea usted al hacer esta declaración referente a Henry Lane Wilson?

Dr. INMAN. Lo he hecho en público.

El PRESIDENTE. ¿Y lo sostiene?

Dr. INMAN. Sí, señor.

El PRESIDENTE. ¿Qué sabe usted de eso, estuvo ahí?

Dr. INMAN. No, señor; no estuve ahí.

El PRESIDENTE. Entonces ¿de dónde obtuvo la información?

Dr. INMAN. Oh, de fuentes estadounidenses y de fuentes mexicanas.

El PRESIDENTE. ¿Qué fuentes estadounidenses?

Dr. INMAN. La prensa estadounidense lo ha declarado varias veces.

El PRESIDENTE. ¿Declarado qué?

Dr. INMAN. Los hechos que se presentan (señalando su libro).

El PRESIDENTE. ¿Me podría usted proporcionar algún artículo que trate el tema en el que se declare que Henry Lane Wilson tuvo algo que ver con este asunto diabólico?

Dr. INMAN. Puedo proporcionarle dichos artículos si regreso a los archivos, lo que sería algo difícil.

El PRESIDENTE. Me imagino que lo sería, Doctor. ¿A través de que fuentes mexicanas se enteró del evento?

Dr. INMAN. Comentarios generales, cotidianos, no recuerdo específicamente a los mexicanos que lo describieron, pero nacionales como el profesor Osuna.

El PRESIDENTE. ¿En dónde se encontraba el profesor Osuna en ese momento? Dr. INMAN. Me parece que estaba en Estados Unidos.

El PRESIDENTE. ¿Qué otro mexicano le dio información sobre el hecho?

Dr. INMAN. No recuerdo al individuo, pero esa es la denuncia.

El PRESIDENTE. Doctor Inman, ¿sabe de estadounidenses residentes en la Ciudad [de México] que estuvieran presentes en la conferencia entre Huerta y Díaz o sus representantes y Henry Lane Wilson?

Dr. INMAN. No lo sé.

El PRESIDENTE. ¿No sabe algo al respecto?

Dr. INMAN. No.

El PRESIDENTE. ¿La información que usted ha transmitido en el párrafo que leí o la declaración que ha hecho están basadas simplemente en las fuentes que acaba de mencionar? 
Dr. INMAN. Probablemente de otras fuentes, considero que hay mucha gente que diría lo mismo.

El PRESIDENTE. Algunos lo han dicho y han sido demandados en la Corte por ello... tuvieron que confesar que no era cierto. ¿Lo sabía?

Dr. INMAN. No.

El PRESIDENTE. ¿No sabe usted que Henry Lane Wilson presentó una demanda por difamación en contra de cierto diario del país?

Dr. INMAN. No, no lo sabía.

El PRESIDENTE. ¿Sabía del cambio de orientación y temática de la revista Harper's Weekly? ${ }^{24}$

Dr. INMAN. No.

El PRESIDENTE. ¿Entonces no sabe que una declaración de este estilo fue juzgada en las cortes?

Dr. INMAN. No.

El PRESIDENTE. Doctor, esas noticias estuvieron disponibles para usted, para mí y, me parece, igualmente para el resto del público.

Dr. INMAN. Es probable, pero seguro que nunca escuché de ellas.

El PRESIDENTE. Bueno, yo no estoy presentando ninguna demanda por difamación y como ciudadano estadounidense no estoy interesado en esa declaración particular. Observo que usted dice aquí "me llama la atención el hecho que desafortunadamente exista fuerte prejuicio en contra nuestra, por el número de estadounidenses que están viviendo en México porque no podían vivir en Estados Unidos. Hemos tenido una gran cantidad de estadounidenses que no pueden explicar porqué se encontraban en México. Naturalmente, no contribuyen en nada para fomentar la amistad entre los dos pueblos". ¿De qué estadounidenses en México tiene conocimiento?

Dr. INMAN. Es un chiste común que se conozca a alguien en el tren y que al hablar con él no debe preguntarse qué es lo que está haciendo en México.

El PRESIDENTE. ¿Alguien le jugó esa broma alguna vez?

Dr. INMAN. Sí, así fue.

El PRESIDENTE. ¿Qué contestó?

Dr. INMAN. Respondía a lo que me dedicaba.

El PRESIDENTE. ¿Alguna vez preguntó a otro estadounidense qué es lo que hacía en México?

Dr. INMAN. Le he preguntado a muchos.

El PRESIDENTE. ¿Y obtuvo usted una respuesta satisfactoria?

Dr. INMAN. De algunos, prácticamente de todos.

El PRESIDENTE. ¿Puede usted recordar un caso en el que no haya sido así?

Dr. INMAN. No, señor; pero me parece que nadie negaría esa afirmación. Creo que hay muchos estadounidenses en México que no podrían explicar por qué estaban allá y no les gustaría explicarlo.

24 Harper's Weekly, A Journal of Civilization fue publicada en Nueva York entre 1857 y 1916, se ganó una alta reputación por los temas abordados, sus ilustraciones y caricatura política, incluido el trabajo de Thomas Nast, el padre de la caricatura estadounidense o los escritos de Charles Dickens, entre otros. 
El PRESIDENTE. ¿Puede usted mencionar a alguno?

Dr. INMAN. No. No he vivido en México por cinco años.

El PRESIDENTE. ¿Usted vivió aquí?

Dr. INMAN. Sí.

El PRESIDENTE. ¿Y no tuvo ningún compañero que estuviera dentro de esa clase de estadounidenses?

Dr. INMAN. Bueno, he tenido conocidos.

El PRESIDENTE. ¿Ha tenido conocidos?

Dr. INMAN. Sí, señor.

El PRESIDENTE. ¿De esa clase de estadounidenses?

Dr. INMAN. Sí.

El PRESIDENTE. ¿Puede mencionar a alguno?

Dr. INMAN. No. Ha pasado mucho tiempo como para recordar.

El PRESIDENTE. ¿Está usted familiarizado con las leyes de extradición entre los Estados Unidos y México?

Dr. INMAN. De manera muy general.

El PRESIDENTE. ¿Sabe si hay algunas excepciones a las ofensas o crímenes que no sean causa de extradición bajo los tratados entre Estados Unidos y México?

Dr. INMAN. Bueno, pienso por ejemplo que los militares prófugos no están incluidos. Cuando estuve allá supe que se informó de una extensa colonia de militares prófugos en México.

El PRESIDENTE. ¿Y ése es el único ejemplo que puede recordar?

Dr. INMAN. Ese es el que me viene a la mente.

El PRESIDENTE. ¿Y esas personas a las que se refiere usted están en su libro?

Dr. INMAN. Sí; a ellas las tuve en mente.

El PRESIDENTE. ¿Entonces por qué no mencionó usted que los militares prófugos que cruzaron [la frontera] durante guerra, para escapar al servicio militar en este país, no contribuyeron a consolidar la amistad entre los dos pueblos? ¿Pensó que los lectores de este libro pudieran leer entre líneas “militares prófugos"?

Dr. INMAN. No; no creí que fuera necesario.

El PRESIDENTE. ¿Es su propósito, o era su propósito, que debieran interpretarlo como "militares prófugos"?

Dr. INMAN. No particularmente, porque los militares prófugos son simplemente una parte de ellos.

El PRESIDENTE. ¿Tiene conocimiento —usted está trabajando en asuntos internacionales y evidentemente pondrá atención al hecho- que nuestros tratados de extradición con prácticamente todos los países, hasta años recientes, estipulan que los infractores políticos no son extraditables? Un prófugo militar es un transgresor político bajo ley marcial, ¿sabe eso?

Dr. INMAN. No.

El PRESIDENTE. En la página 147 de su libro menciona dos casos de actos hostiles a estadounidenses en México, el segundo de ellos es el siguiente:

"El otro caso de hostilidad hacia los estadounidenses es la orden general que [Victoriano] Huerta dio al momento de la toma de Veracruz, de arrestar a todos los estadounidenses que estuvieran en México. Muchos de ellos destacados, incluyendo nuestros funcionarios consulares, que fueron enviados a prisión 
y se les mantuvo allí hasta que las autoridades carrancistas los liberaron y posteriormente recuperaron los poblados donde estaban presos".

¿Basado en qué fuentes hizo usted esa afirmación?

Dr. INMAN. Una fuente autorizada, el General Hanna, cónsul en Monterrey.

El PRESIDENTE. ¿Dónde se encuentra el General Hanna?

Dr. INMAN. Monterrey.

El PRESIDENTE. ¿En este momento?

Dr. INMAN. Sí.

El PRESIDENTE. ¿Alguna otra fuente?

Dr. INMAN. Es la que recuerdo específicamente.

El PRESIDENTE. El General Hanna — la única fuente que usted recuerda - le dijo que Huerta expidió una orden general al momento en que tomamos Veracruz ¿Arrestar a todos los estadounidenses en México, el General Hanna le dijo eso? Dr. INMAN. No; no dijo eso.

El PRESIDENTE. ¿Quién le dijo? "Muchos estadounidenses destacados, incluyendo nuestros funcionarios consulares, que fueron enviados a prisión y se les mantuvo allí hasta que las autoridades carrancistas los liberaron y posteriormente recuperaron los poblados donde estaban presos."

Dr. INMAN. Hice referencia particular a su propio caso.

El PRESIDENTE. Que capturaron después los poblados donde estaban presos. ¿Quiere decir que el propio General Hanna fue arrestado por orden de Huerta? ¿Él le afirmó eso?

Dr. INMAN. Sí, señor.

El PRESIDENTE. ¿Está usted seguro de eso?

Dr. INMAN. Sí.

El PRESIDENTE. ¿Cómo lo sabe?

Dr. INMAN. Bueno, de palabra de...

El PRESIDENTE. ¿Cómo fue arrestado?

Dr. INMAN. Por el general o quien quiera que estaba allá en Monterey.

El PRESIDENTE. ¿Bajo una orden general?

Dr. INMAN. La disposición fue general hubo pruebas de eso porque un número de nuestros misioneros también fueron hechos prisioneros al mismo tiempo.

El PRESIDENTE. A eso es a lo que llegamos ahora.

Dr. INMAN. El cónsul Sillman y uno de nuestros misioneros en Saltillo fueron hechos prisioneros al mismo tiempo.

El PRESIDENTE. ¿Y qué fue de ellos?

Dr. INMAN. El General Hanna fue liberado inmediatamente.

El PRESIDENTE. ¿Liberado inmediatamente?

Dr. INMAN. Fue liberado de inmediato cuando los soldados carrancistas llegaron.

El PRESIDENTE. ¿Cuánto tiempo estuvo encarcelado?

Dr. INMAN. Solamente durante una batalla.

El PRESIDENTE. ¿No es un hecho que el General Hanna fue custodiado bajo las órdenes de las autoridades militares, con el propósito de protegerlo de los ataques de la muchedumbre debido a la agitación levantada por el desembarco de las tropas en Veracruz?

Dr. INMAN. No, señor.

El PRESIDENTE. ¿No es eso cierto? 
Dr. INMAN. No, según la historia que él mismo me contó.

El PRESIDENTE. ¿Y fue arrestado, dice usted, porque era estadounidense?

Dr. INMAN. Fue arrestado por ser estadounidense y llevado a prisión, obligado a seguir caminando y el populacho mismo gritaba ¡Vergüenza! Y los líderes se vieron obligados a conseguir un carruaje.

El PRESIDENTE. Queremos llegar a la verdad de esto. ¿Quién fue el general carrancista que lo liberó?

Dr. INMAN. No recuerdo quién estaba al mando en ese momento.

El PRESIDENTE. Usted hizo esta afirmación y todavía quiere que se difunda como lo ha hecho, que Huerta expidió esa orden para arrestar estadounidenses en México y bajo esa orden muchos estadounidenses destacados, incluyendo nuestros funcionarios consulares fueron enviados a prisión y permanecieron allí hasta que las autoridades carrancistas los liberaron...

Dr. INMAN. Exactamente, así es.

El PRESIDENTE. De hecho, usted dice que este señor Hanna, o General Hanna, lo que sea correcto, fue arrestado durante una batalla y que esa batalla fue cuando las fuerzas que estaban aliadas con Carranza tomaron Monterey ¿Fue así? ¿Es esa la batalla a la que usted hace referencia?

Dr. INMAN. No recuerdo qué batalla fue o quién era el comandante.

El PRESIDENTE. ¿Fue arrestado durante la batalla y liberado casi de inmediato, porque las fuerzas carrancistas que ocuparon el lugar lo liberaron al momento?

Dr. INMAN. Pudo haber sido arrestado antes de la batalla.

El PRESIDENTE. ¿Cuánto tiempo antes de la batalla?

Dr. INMAN. No lo sé. Me parece fueron solamente un par de días los que en total estuvo retenido en prisión.

El PRESIDENTE. ¿Cuánto tiempo permaneció en la cárcel el Dr. Sillman?

Dr. INMAN. Creo que fueron varios meses, varias semanas por lo menos.

El PRESIDENTE. ¿Quién más fue retenido en prisión?

Dr. INMAN. Los misioneros que estaban con el señor Sillman en ese momento.

El PRESIDENTE. ¿En dónde estaban ellos?

Dr. INMAN. En Saltillo, y algunos de nuestros misioneros fueron arrestados en Querétaro y Guanajuato.

El PRESIDENTE. ¿Estaban en operación las líneas telegráficas entre Saltillo y Monterey?

Dr. INMAN. No lo sé. Supongo que muchas de ellas fueron cortadas, porque era...

El PRESIDENTE. ¿Estaban en operación las líneas telegráficas entre Saltillo y Monterey?

Dr. INMAN. No lo sé.

El PRESIDENTE. ¿Estaban en operación entre Monterey y la frontera?

Dr. INMAN. No lo sé.

El PRESIDENTE. ¿Y no lograron el señor Sillman y el general Hanna enviar un mensaje telegráfico a Estados Unidos?

Dr. INMAN. No lo sé.

El PRESIDENTE. ¿No fue posible para ellos comunicarse telegráficamente a la Ciudad de México? 
Dr. INMAN. No tengo forma de saber en qué condiciones estaban las líneas telegráficas en ese momento.

El PRESIDENTE. Bueno, si las líneas que comunicaban a la Ciudad de México estaban derribadas ¿Cómo pudo el general Huerta comunicar una orden para arrestarlos?

Dr. INMAN. No digo que estuvieran derribadas; no sé cuál era el estado de las líneas en ese momento.

El PRESIDENTE. ¿Alguien fue arrestado en la Ciudad de México, algún estadounidense?

Dr. INMAN. No recuerdo ningún detalle...

El PRESIDENTE (interrumpiendo). ¿Recuerda usted de manera general o escuchó del arresto de algún estadounidense en la Ciudad de México bajo esa orden de Huerta? ¿En dónde se encontraba Huerta?

Dr. INMAN. Digo que no recuerdo haber escuchado que alguien hubieran sido arrestado.

El PRESIDENTE. ¿Conoce usted a Nelson O'Shaughnessy?

Dr. INMAN. No personalmente; pero sé de él.

El PRESIDENTE. ¿Quién era?

Dr. INMAN. Era el encargado de negocios.

El PRESIDENTE. ¿En dónde se encontraba en el momento en que ocupamos Veracruz?

Dr. INMAN. Si recuerdo con precisión estaba en la Ciudad de México en ese momento.

El PRESIDENTE. ¿Estaba en la Ciudad de México? ¿Cómo logró salir?

Dr. INMAN. Me parece que permaneció allí por un tiempo.

El PRESIDENTE. ¿Fue liberado por Carranza?

Dr. INMAN. No.

El PRESIDENTE. ¿Fue arrestado por Huerta?

Dr. INMAN. No que yo sepa.

El PRESIDENTE. ¿Realmente escuchó usted algo de lo que sucedió allá?

Dr. INMAN. Creo que sí, pero no lo tengo claro en mi recuerdo. Leí el libro de la señora O'Shaughnessy.

El PRESIDENTE. ¿Y no consideró conveniente citar alguna de las cosas que aparecen en el libro de la señora O'Shaugnessy en su libro?

Dr. INMAN. Bueno, yo...

El PRESIDENTE. Si lo hubiera hecho, recordaría usted el hecho mencionado en ese libro, que el señor Huerta protegió la embajada estadounidense, al encargado de negocios y a los estadounidenses que estaban allí. Y que cuando salieron de la Ciudad de México se fueron seguidos por una escolta militar provista por Huerta. Dr. INMAN. Podría haber recordado ese evento, pero el otro hecho lo tenía muy presente porque tuve amigos vinculados a él. No recuerdo el caso de la Ciudad de México, pero sí tengo en mente el hecho de que varios amigos míos fueron arrestados.

El PRESIDENTE. ¿Sabe usted que el general Huerta está muerto y puede estar ahora expiando sus pecados? ¿Piensa tener justificación para poner esta mancha adicional contra su nombre, que expidió una orden para arrestar a todos los estadounidenses en México? 
Dr. INMAN. Sin duda es lo que entendí de esos misioneros que fueron arrestados. El PRESIDENTE. Y aún así usted dice que dado que en Saltillo y Monterey, los carrancistas estaban atacando los poblados, en la Ciudad de México los estadounidenses no fueron arrestados...

Dr. INMAN (interrumpiendo). Dije que Querétaro y Guanajuato, en ambos lugares hubo órdenes generales y arrestaron misioneros.

El PRESIDENTE. ¿Puede usted dar los nombres de alguno de sus misioneros que vieron tales órdenes? ¿Usted mismo las vio?

Dr. INMAN. No.

El PRESIDENTE. ¿Puede usted darme los nombres de algunos de los misioneros que vieron las órdenes?

Dr. INMAN. No; pero puedo darle los nombres de quienes fueron arrestados. En México las órdenes generalmente no se muestran.

El PRESIDENTE. ¿Sabe usted que bajo la Constitución mexicana, que era observada por Huerta, no se puede arrestar a un hombre sin una orden escrita para su arresto?

Dr. INMAN. Sé que las órdenes no fueron mostradas.

El PRESIDENTE. Sucede que más de un caso que ha sido sometido a mi observación...

Dr. INMAN. Bueno, muchas no fueron mostradas.

El PRESIDENTE. ¿Y usted sólo conoce de un caso?

Dr. INMAN. A estos misioneros simplemente se les dijo que eran arrestados bajo órdenes.

El PRESIDENTE. Usted afirma en su libro que fueron arrestados bajo las órdenes de Huerta.

Dr. INMAN. Sí, señor.

El PRESIDENTE. ¿Y usted escribió que expidió una orden general?

Dr. INMAN. Esa es la opinión de todas las personas que fueron arrestadas en diferentes partes del país.

El PRESIDENTE. Hay varias personas en esta sala que estuvieron en México en aquel momento, algunos en la Ciudad de México bastante familiarizados con las condiciones imperantes allá. Creo que podemos obtener algo de información sobre ellos.

Senador BRANDEGEE. ¿Cuál fue el propósito de Huerta al expedir esa orden general? ¿Qué piensa, cuál fue la razón de hacerlo?

Dr. INMAN. Su resentimiento por la invasión de las tropas estadounidenses.

Senador BRANDEGEE. ¿Se levantó algún cargo en contra de estas personas arrestadas bajo esta orden?

Dr. INMAN. No, simplemente por ser estadounidenses.

Senador BRANDEGEE. ¿Por qué Huerta no arrestó a O’Shaughnessy, dado que había arrestado al general Hanna?

Dr. INMAN. No consideró que fuera políticamente correcto aplicar las mismas medidas en la capital de la República y en los poblados más pequeños.

Senador BRANDEGEE. Él tenía el control de la capital de la República Dr. INMAN. Sí, señor. 
Senador BRANDEGEE. ¿Tiene noticia de alguna corporación o sujeto estadounidense que tuviese intereses en el país, lo que usted llama "explotar a la gente de México"?

Dr. INMAN. No, no lo sé.

Senador BRANDEGEE. ¿Conoce de algún plan extranjero, diferente al estadounidense, que los esté explotando?

Dr. INMAN. No, señor.

El PRESIDENTE. Doctor, observo que en la página 3, en donde expone la intención de su libro, dice: "Espero mostrar, sobre todo porque tuve la oportunidad especial de conocerla, la perspectiva mexicana del asunto". ¿Qué quiere decir con eso?

Dr. INMAN. Bueno, quiero decir que habiendo vivido en México por diez años y haber conocido intensamente a una gran cantidad de mexicanos -incluyendo funcionarios del gobierno anterior, funcionarios del gobierno actual y un gran número de alumnos de mi propia escuela que fueron a la revolución- $-\mathrm{y}$ convivido personalmente con ellos, pensé haber tenido oportunidades concretas de saber qué pensaban sobre el asunto.

El PRESIDENTE. ¿Algún mexicano le suministró información para la compilación de este libro?

Dr. INMAN. No.

El PRESIDENTE. ¿Tuvo alguna ayuda de ellos?

Dr. INMAN. No.

El PRESIDENTE. Usted ha estado fuera de México por varios años. ¿Estuvo allí durante la revolución?

Dr. INMAN. Estuve ahí durante, lo que podría decirse, fue la peor parte de la revolución.

El PRESIDENTE. ¿Cuándo?

Dr. INMAN. Hacia 1915.

El PRESIDENTE. ¿En ese momento qué puesto ocupaba su querido amigo, el general Osuna?

Dr. INMAN. El general Osuna se hallaba viviendo en Estados Unidos.

El PRESIDENTE. Desde que salió de México, y desde que Carranza fue reconocido en 1915, ha estado viviendo únicamente en Estados Unidos. ¿Ha hecho uno o dos viajes de regreso a México?

Dr. INMAN. Sí, señor.

El PRESIDENTE. Y aún así ¿piensa estar completamente informado de la actualidad, como para escribir sobre lo que usted llama "el lado mexicano de la revolución", y presentar las condiciones reinantes a los estadounidenses?

Dr. INMAN. Señor Presidente, no afirmo saber todo sobre la materia, pero consideré que debía dar un mensaje a la gente. No era mi intención presentar al público un libro más o algo por el estilo, lo escribí a partir de un sentido de obligación como ciudadano estadounidense, como alguien interesado en el trabajo misional en México y preocupado por el país mismo. Tengo una gran cantidad de amigos allá por quienes tengo profunda confianza, pero al mismo tiempo me pareció que era correcto continuar, exponer mi teoría general en las cuestiones mexicanas y nuestras relaciones con ese país. 
El PRESIDENTE. ¿Cuánto tiempo le tomó preparar este libro? ¿Cuánto tiempo tardó en escribirlo?

Dr. INMAN. Escribí algunos de esos capítulos prácticamente en febrero, cuando estaba en México, el libro fue entregado a la imprenta, me parece, en junio. En aquel entonces trabajaba en él durante el tiempo que tenía libre, generalmente de diez de la noche hasta aproximadamente dos o tres de la mañana.

El PRESIDENENTE. ¿Alguien escribió el libro por usted o alguna parte de él?

Dr. INMAN. No, señor.

El PRESIDENTE. ¿Usted lo escribió todo?

Dr. INMAN. Tampoco nadie me sugirió que lo escribiera.

El PRESIDENTE. ¿Y alguien le aportó información?

Dr. INMAN. No, señor; es una producción absolutamente mía, nadie conoce sus limitaciones más que yo; pero en todo caso no me arrepiento de haber escrito el libro. Sostengo lo que dice.

El PRESIDENTE. Yo no tengo ninguna razón para lamentarlo, Doctor; así que ambos estamos satisfechos.

Dr. INMAN. Tal vez si tuviéramos una ley que dejara fuera autores que escriben tantos libros sería benéfico, pero en tanto que todos estén escribiéndolos pensé que yo también podía hacerlo.

El PRESIDENTE. Usted lo ha titulado "Intervención en México" y dice haber estado involucrado en propaganda y divulgación en franca oposición a la intromisión en México. Supongo que eligió un momento afortunado para escribirlo y publicarlo [aunque] no veo que eso haya sucedido sin querer. ¿Ese fue el propósito?

Dr. INMAN. Quise decir que cuando comencé a escribirlo, no había ni remotamente el interés por México que después se desarrolló.

El PRESIDENTE. Al final pienso que su libro ha aportado en gran medida al interés por los asuntos mexicanos.

Dr. INMAN. Gracias, señor. 